Southern Illinois University Carbondale OpenSIUC

Publications

Department of Geography and Environmental

Resources

$3-1999$

\title{
Factors in Organic Farmers' Decisionmaking: Diversity, Challenge, and Obstacles
}

Leslie Duram

Southern Illinois University Carbondale, duram@siu.edu

Follow this and additional works at: http:// opensiuc.lib.siu.edu/gers_pubs

Published in American Journal of Alternative Agriculture, Vol. 14 No. 1 (March 1999) at doi: 10.1017 / S0889189300007955

\section{Recommended Citation}

Duram, Leslie. "Factors in Organic Farmers' Decisionmaking: Diversity, Challenge, and Obstacles." (Mar 1999).

This Article is brought to you for free and open access by the Department of Geography and Environmental Resources at OpenSIUC. It has been accepted for inclusion in Publications by an authorized administrator of OpenSIUC. For more information, please contact opensiuc@lib.siu.edu. 


\title{
Factors in organic farmers' decisionmaking: Diversity, challenge, and obstacles
}

\author{
Leslie A. Duram
}

Abstract. This research promotes our understanding of organic farmers' decisionmaking through individual farmers' experiences. A twofold survey was conducted to investigate characteristics of certified organic farmers in Colorado. Data from a mail survey (26 responses to 49 surveys sent) reveal patterns of farm operations and attitudes among this group of farmers. These questionnaires focused on land use, land tenure, operational change, and personal characteristics. In-depth interviews of five case study farmers provide additional insight into farmers' agricultural decisionmaking. These interviews were conversations that the farmers guided toward topics of relevance to them. Taken together, the mail and interview surveys provided information about on-farm operational factors and personal characteristics. Quantitative analysis and qualitative data reduction techniques were used to identify factors in organic farmer decisionmaking. The following eight factors help us understand organic agriculture in this region: diversity, challenge, change, businesslike approach, no formal agricultural education, love of the land, anti"radical environmentalist," and obstacles.

Key words: organic agriculture, operational change, behavior

Organic farming is often considered outside mainstream agriculture, yet 1 to $8 \%$ of American farmers are using methods characteristic of organic farming (Benbrook, 1995; Dunn, 1995). There is a valuable literature on the broader topic of "sustainable" agricultural decisionmaking that includes social factors such as information sources and farm structure (Padgitt and Petrzelka, 1994; Salamon et al., 1997). Yet the question remains: who are the farmers who specifically decide to adopt organic methods, which are outside the practices used by most of the agricultural community? Previous studies compared certified organic and conventional operations regarding yields and economic returns (Lockeretz et al., 1978, 1981; Lockeretz and Madden, 1987; Stanhill, 1990; Smolik and Dobbs, 1991; Batte et al.,

Leslie A. Duram is Assistant Professor, Department of Geography, Southern Illinois University, Carbondale, IL 62901-4514; duram@siu.edu.
1993). Fewer studies have compared operational and attitudinal distinctions between conventional and organic farming (Buttel and Gillespie, 1988; Duram, 1997). Still fewer studies have investigated deeply the wide array of social and environmental factors that influence organic farmers in a specific region (Lockeretz, 1997). This last approach is important for understanding the unique regional and local variations in organic operations, which is necessary for developing appropriate policies and public knowledge.

Organic farming provides an opportunity to study a distinct agricultural decisionmaking process. Specifically, the choice to adopt organic (as opposed to more general "sustainable") methods requires farmers to face at least two unique barriers: sudden dramatic operational change, and lack of support and information. First, farmers must take a dramatic "leap of faith" - a definitive change in methods rather than a gradual transition to similar methods. Farms must be free of prohibited chemicals during a transition period, which typically is three years; during this time farmers do not receive premium prices (Duram, 1998). Thus, farmers must be willing to make dramatic operational changes that expose them to increased risk while they are learning new techniques. They also must seek new sources of information on organic methods. In the decision to adopt new agricultural methods, farmers typically seek information from neighboring farmers, local chemical dealers, and local government agencies (Korsching and Hoban, 1990). However, these sources do not provide adequate information on organic methods. In addition, university agricultural researchers may overlook the option of organic methods because of their previous training (Beus and Dunlap, 1992). Thus farmers must be willing to search out diverse, alternative sources of information that are not local or obvious.

Because of these complex factors, organic farmers' decisions must be studied holistically. Important details vary by farmer and locale; when we view them together, we can glean insight into the future adoption of alternative agricultural methods. In this article, I describe the farm operations and personal characteristics of a group of certified organic farmers in Colorado. Quantitative and qualitative analysis of the surveys yielded findings about farmers' decisionmaking and motivations, identifying eight key characteristics that are valuable in understanding organic farmers and their farms.

\section{Methods}

A twofold survey done in 1994, with follow-up interviews in 1996, illuminated 
the attitudes and characteristics of certified organic farmers in Colorado. Because I sought to understand fully the decisionmaking context of these farmers, I used written and interview surveys simultaneously. These provided different but complementary data. The mail surveys, in multiple choice and short answer format, gathered specific information on operations, personal characteristics, and factors in decisionmaking. The interviews, on the other hand, were conversational and sought out topics that individual farmers perceived as important. I began the interviews by asking, "Why are you in farming?" and then "Why are you in organic farming?" and a rich discussion followed. If there was a lull in conyersation, I would prompt farmers with comments like "please explain why do you use these types of crop rotations." I had several contacts with each case study farmer through onfarm visits and telephone conversations.

The farmers contacted were members of the statewide Colorado Organic Producers Association (COPA), a marketing organization of 49 members that disseminates information on organic production in the state (COPA, 1993). The one-time mail questionnaires were sent to all 49 COPA members; the analysis was done on the 26 organic farmers who responded (53\% response rate). Mail survey respondents were of the following operational types: two dryland organic farmers, nineteen irrigated organic farmers, and five organic ranchers. To provide a richer, holistic understanding of the personal characteristics and motivations behind the adoption of organic methods, I conducted in-depth, multiple-day interviews with five farmers. These case study farmers did not receive the mail survey; rather, they were selected because they were willing to participate in lengthy on-farm interviews and because they represented various farm types in northeastern Colorado. Case study organic farms were of the following types: irrigated herb farm, irrigated vegetable farm, crop and livestock farm, dryland grain farm, and ranch (Table 1). (The names of case study farmers have been changed to provide anonymity.)

Quantitative and qualitative analyses are complementary and provide depth and breadth to our understanding of a topic

Table 1: Characteristics of case study organic farmers.

\begin{tabular}{|c|c|c|c|c|c|c|c|}
\hline Farmers ${ }^{I}$ & Ages & $\begin{array}{c}\text { Type of } \\
\text { Operation }\end{array}$ & $\begin{array}{l}\text { Land } \\
\text { (acres) }\end{array}$ & $\begin{array}{l}\text { Year } \\
\text { estab. }\end{array}$ & $\begin{array}{c}\text { Year } \\
\text { organic }\end{array}$ & $\begin{array}{l}\text { Annual Pre- } \\
\text { cipitation } \\
\text { (inches) }\end{array}$ & $\begin{array}{l}\text { Irri- } \\
\text { gated }\end{array}$ \\
\hline Andy & 38 & irrigated herb & 8 & 1983 & 1983 & 19 & yes \\
\hline Tina \& Joe & $30 / 36$ & crop \& livestock & 750 & 1984 & 1989 & 14 & yes \\
\hline Lewis & 72 & irrigated veg. & 2,000 & 1971 & 1981 & 13 & yes \\
\hline Natalie \& Cal & $51 / 57$ & dryland grain & 3,500 & 1960 & 1977 & 15 & no \\
\hline Jack & 60 & ranch & 8,000 & 1961 & 1985 & 17 & no \\
\hline
\end{tabular}

1 Names changed to provide anonymity

(Miles and Huberman, 1994). For quantitative analysis, I used descriptive statistics for farm size, main types of crops, age of farmers, and other quantifiable variables. Qualitative analysis of interview data involved data reduction techniques, categorization of responses, and discovery of themes among participants.

In this research, I addressed the growing concern that gender roles are reinforced in agricultural research (Allen and Sachs, 1993). Case study farmers were initially contacted by mail with an introductory letter. These were addressed according to the COPA listing; therefore, some letters were sent to male farmers, some to female farmers, and some to both the male and female partners. When I called to arrange the interview appointments, I spoke with whoever was willing to talk. On some farms, the husband and wife made operational decisions jointly, while on other farms one spouse worked off-farm while the other spouse was the primary decisionmaker. My interviews were held with the decisionmaker(s) who felt knowledgeable about their operation and were willing to discuss them.

The mail and interview surveys gathered information on four categories: overview of farm operations; adoption of organic methods; farmer characteristics; and farmers' motivations and attitudes. The specific information included in each category is shown in Table 2.

\section{Results}

\section{Overview of farm operations}

Farm size, type and tenure. Given the diversity of organic operations, it is a challenge to describe average farm size meaningfully. The surveyed farms and ranches varied from 2 to 12,000 acres, with several dryland grain farms over 3,000 acres and several ranches over 7,000 acres (excluding public lands rented annually for grazing) (Table 3). Further complicating the issue is that the census definition of "farm" size includes ranches, which often are extremely large. Mean size of the respondents' farms was 1,611 acres when ranches are included, but 617 acres when pure ranching operations are excluded. The statewide average farm size is 1,252 acres (including ranches), and 298 acres if only the farms with harvested cropland are considered (Bureau of the Census, 1992). Thus, the organic farms are larger than the statewide average farm size, both when ranches are included and when cropland farms alone are considered. Many organic operations are highly diverse; many certified organic ranchers also have cropland, and many organic crop farmers also have some livestock. This diversity affects the farm size figures. Median organic farm size was 170 acres, which shows that there are many small organic farms (especially vegetable and orchard operations).

Farm type also is a complex issue. Of the 26 surveyed farmers, some maintain mixed cropping and livestock operations, with or without irrigation, which makes it difficult to categorize the farms neatly. Twenty are pure crop operations, three are pure cattle ranching operations, and three have both. Also, 19 of the 26 have some irrigated land; their average size is 505 acres, compared with the statewide average of 363 acres (Bureau of the Census, 1992). 
Table 2. Questions on objective mail survey. ${ }^{I}$

\begin{tabular}{ll}
\hline Operations & General Information \\
\hline type (dryland, irrigated, mixed) & why farming \\
diversification & off-farm income \\
size & household members \\
year established & farm workers \\
year organic & ethnic background \\
tenure & community affinity \\
child participation & participation in organizations \\
land use & environmental issues \\
water availability & conservation literature \\
government programs & defining agroecosystems \\
operational change & gross operational income \\
input change & \\
plans for change & \\
\hline
\end{tabular}

${ }^{I}$ Multiple-choice and short-answer format

Table 3. Size distribution of surveyed organic farms $(n=26){ }^{1}$

\begin{tabular}{lcl}
\hline Size (acres) & Number & \\
\hline $1-9$ & 5 & \\
$10-49$ & 3 & median farm and ranch size $=170$ \\
$50-179$ & 5 & \\
$180-499$ & 2 & mean cropland farm size $=617$ \\
$500-999$ & 5 & mean farm and ranch size $=1611$ \\
$1000-1999$ & 0 & \\
$2000+$ & 6 &
\end{tabular}

${ }^{1}$ Land farmed, both owned and rented, excluding federal grazing lands.

${ }^{2}$ U.S. Census of Agriculture acreage categories

The case study farmers had operations of the following sizes (Table 1): Andy, 8 acres; Tina and Joe, 760; Lewis, 2033; Natalie and Cal, 3562; Jack, 8,000 (a certified organic ranch). Three of these farms (Tina and Joe's, Natalie and Cal's, and Jack's) were grain or ranch operations, and had at least some land that was inherited. In these cases the farmers felt a particularly close affinity with the region, having lived there most of their lives. The 8- and 2033-acre farms (Andy and Lewis) primarily were vegetable operations. These farmers were newer to agriculture and to their local area, having lived there 10 to 25 years, respectively. Case study farmers said that low annual precipitation (Table 1) and the short growing season (125 to 130 days) were important decisionmaking factors in this region. These land tenure and climatic factors influence the personal characteristics and motivations noted below.

Financial status. My research goals did not include determining the profit margin of each organic farmer. Most farmers believe this is private information, and asking pointed financial questions would have greatly inhibited my ability to discover all other relevant personal data. Asking about a farmer's perception of profit, however, was very useful, as it showed their view of the relative success of their farming operation. Twenty-nine percent of the organic farmers said that their operations were "quite profitable," $45 \%$ reported "some profits," $21 \%$ said they "break even," and one (4\%) lost money. These farmers did not espouse romantic ideals of agrarianism (Danbom, 1991). Rather, they expressed realistic businesslike attitudes toward profits on their farms.

A relative measure of the size of an operation was gross operational income (Table 4). The median reported estimated gross operational income was in the $\$ 100,000-150,000$ range. However, a large proportion (46\%) of these producers had gross operational incomes over $\$ 150,000$, while $31 \%$ were under $\$ 40,000$. This shows that some organic farmers are financial managers as much as physical field workers. Furthermore, the high gross
Table 4. Distribution of farmers' reported gross operational income $(n=25)$.

\begin{tabular}{ll}
\hline Income $\mathbf{( \$ 1 , 0 0 0 )}$ & Number \\
\hline$<20$ & 4 \\
$20-40$ & 4 \\
$40-60$ & 2 \\
$60-80$ & 0 \\
$80-100$ & 2 \\
$100-150$ & 1 median income \\
$>150$ & 12 \\
\hline
\end{tabular}

operational income reported by some respondents contradicts the common stereotype that organic farming is possible only at a garden scale and is not economically viable. There is no clear correlation between high gross operational income and amount of land (Table 5). Farms with income over $\$ 150,000$ ranged from just 8 acres to 12,000 acres, with a mean of 2,700 acres. On the other hand, some smaller farms had lower gross operational incomes, as farms operating at $\$ 40,000$ or under ranged from 2 to 170 acres, with an average of 35 acres.

There are similar levels of off-farm employment among the organic farm households (54\%) and farm households statewide (51\%) (Bureau of the Census, 1992). On the surveyed organic farms where there is any off-farm work, it contributes from as little as $10 \%$ to as much as $95 \%$ of total household income. This variation is related to the large variation in gross operational income reported above.

Case study farmers held positive and complex opinions about their financial status. Natalie noted that "the neighbors think we're loony-tunes for doing organic"; her husband, Cal, agrees that other farmers "think we don't have both oars in the water." But she also said that "neighbors see the good financial situation with organic: we're buying land, updating. . . . You can't argue with success!" Joe warned that "organic distributors and middlemen try to increase their own profit share. Middlemen think there is a lot of money in organic. Often they mark it up five times." Jack clarified the organic pricing: "Natural beef gets $\$ 60-250$ per head premium over conventional cattle. But that's not profit! It costs way more to produce it, too."

Crop types and rotations. There is great variety in the crops grown and the rotations of those crops, with 23 different 
Table 5. Farm size by gross operational income.

\begin{tabular}{lcrl}
\hline & & \multicolumn{2}{c}{ Size (acres) } \\
\cline { 3 - 4 } Income $\mathbf{( \$ 1 , 0 0 0 )}$ & Number of farms & Average & Range \\
\hline$<20$ & 4 & 25 & $2-75$ \\
$20-40$ & 4 & 49 & $3-170$ \\
$40-60$ & 3 & 160 & $10-360$ \\
$60-80$ & 0 & -- & - \\
$80-100$ & 2 & 3,885 & $70-7,700$ \\
$100-150$ & 1 & 600 & 600 \\
$>150$ & 12 & 2,718 & $8-12,000$ \\
& & & $2-12,000$ \\
\hline
\end{tabular}

types of crops grown organically by the respondents: alfalfa, barley, beans, beets (sugar), blue corn, corn, flowers/plants, fruit, grapes (vineyard), hay, herbs, millet, oats, onions, potatoes, quinoa, rye, safflowers, sunflowers, tree fruits (orchard), triticale, vegetables (over 20 types), and wheat. Some farmers had monocrop tree fruit operations. Most others had diverse cropping systems, typically growing at least five different crops. Asked "Why do you farm these types of crops?", $43 \%$ of the producers said that their particular crops "best suit the operation." Natalie explained that "we try anything-even crops that nobody grows around here-if it helps our soil or fits into our rotation." This is a holistic viewpoint in which they regard their farm as a unit made up of interdependent parts, a concept linked to the term agroecology (Altieri, 1995).

Lewis noted in his interview that "profitability is number 1 , and number 2 is diversity." His 2,033-acre farm is highly diverse, with 40 vegetables, a few grain crops, flowers, trees for Christmas and landscaping, and a small cattle herd. Andy explained: "I have carved out a specialized market and crops. It changes from year to year." He relies on specialty herbs, salad greens, bedding plants and cut flowers on his 8-acre farm, which has a gross operational income of over $\$ 150,000$ per year. His greenhouse complements his field operation.

Cattle are the most prevalent livestock type, but there are various other animals (goats, ducks, chickens, hogs, and sheep). There is notable diversity among organic farmers who have both crops and livestock. Jack sells about 700 cattle each year and raises 600 acres of dryland wheat on his 8,000-acre operation.
The crop farmers noted their particular methods for working their crops in a certain pattern on certain fields to reduce pest species, rejuvenate the soil, or receive the highest financial return. Joe explained that his rotation schemes are complex and vary from field to field, but he commonly uses a rotation of grain, sugar beets, and corn or barley, or of hay, corn, beets, barley, corn, and beets. He grows some beets organically, but does not sell them that way; they are needed in the rotation on organic fields, but there is no organic beet market yet.

Inputs. The nonuse of pesticides was expected to distinguish organic production, but the matter was not so simple: $19 \%$ of the organic producers said that they used pesticides. There are two reasons for this response. Some organic farmers apply natural soaps and organic pest treatments that are allowed within certified organic production. In addition, these responses reflect the transition to organic agriculture, since some farmers have shifted to certified organic production on some fields but continue to farm other uncertified fields using conventional methods, including pesticides. Organic and conventional crops must be grown, harvested, and stored separately with uncontaminated equipment (U.S. Dept. of Agriculture, 1994). Fertilizers most commonly listed by organic producers are manure, compost, fish-seaweed based, and mineral fertilizers.

Andy expressed a common viewpoint among organic farmers toward conventional agriculture and its use of agrichemicals: "Conventional is the set way of doing it, and it uses chemicals. If you depend on one crop, you need chemicals to save the crop. You need chemicals for security.
That is OK." Joe explained that "you need diversity in organics."

Government programs. Forty-two percent of the respondents said they are enrolled in government programs, at both state and federal levels. However, these programs were broadly interpreted by the farmers to include acreage setasides, feed grain/small grain programs, wildlife fencing, disaster insurance, and alternative wildlife area programs. Case study farmers expressed dislike and distrust of federal farm programs, but several had opinions that contradicted their actions. For example, as Jack noted: "People are farming the government. It should be like the cattle business: nobody bolstering them up. All supply and demand. Wheat and corn depend on the government. It's wrong." While his cattle were outside the government support programs, he did have an allotted acreage in the wheat program. He explained: "You stay within a certain number of acres and get a welfare check. I don't think anything of it." Recent federal legislation will alter these programs over the next decade.

Balancing profit and other concerns. Farmers were asked to explain how they balance "total concern with short-term profit maximization" against eight other factors in agricultural decisionmaking. This was in a scaled format, from 1 to 5 , with 1 representing profit maximization, 3 representing even balance, and 5 representing the other variables. The farmers noted that they evenly balance short-term profit maximization with their concerns about community norms, reducing debt, minimizing risks, and minimizing investments. On the other hand, they said that preservation of environmental quality, preserving long-term productivity of the land, being their own boss, and honoring their personal ideals was more important than short-term profit maximization in their decisionmaking process.

\section{Adoption of organic methods}

Past operational changes. The process by which farmers decide to adopt organic methods was investigated through questions on past and possible future changes in their farming operations. Two-thirds of 
the organic farmers said that their operations had changed in recent years, with change taking the form of "going more organic," "selling directly to consumers," and "farming more intensively." Half reported that the size of their operation had changed, with $31 \%$ increasing and $19 \%$ decreasing. Sixty-two percent changed to a more diversified crop mix or added new facilities; $42 \%$ had changed the way they use pesticides, which they described as going "more organic." Half the farmers had changed their fertilizer use, mostly to "more organic" fertilizers and "more manure."

Future operational changes. Nearly half $(44 \%)$ of the farmers have plans to change the use of their land in the future. The question "Under what conditions would you change the use of your land?" investigated the influences on their landuse decisions. One-third noted they would change to be more profitable. In addition, farmers said that personal family demands, changes in consumer preference, and their ability to buy more land would also influence their future land use. The survey showed that many farmers were likely to increase the size of their operations in the future. Buying more land was either "very likely" or "given serious thought" among half the farmers, and twothirds were considering renting additional land. Soil conditions, personal environmental concern, and farmers' knowledge and experience in land use were the most important factors in their land-use decisions. On the other hand, community pressures and government support policies, factors that often influence conventional farmers (Swanson et al., 1986; Smolik et al., 1995), were not important considerations for these organic farmers.

Key organic operational changes. Interviews provided a particularly valuable way to explore the operational changes that are important in organic production. A major shift is required for farmers to succeed in marketing organic crops, as they must identify alternative markets, smaller wholesalers, and direct marketing options. Joe put it this way: "Most farmers think there is only one place to sell grain: to the local elevator. Most farmers want to haul it to town and dump it. Farmers think that organic is too different and too risky because they don't know about it; don't know how to sell it. You have got to get on the phone and find out. Lots of guys don't want to try anything different. But that is boring!" Natalie agrees: "Farmers have a 'prove it to me' mentality. I've read that it takes farmers 12 years to adopt a proven practice! It's true. It's also driven by economics; bankers control what we do." She also noted that "the downside to organic is the flaky people you have to deal with," explaining that it took them eight months to get $\$ 60,000$ from one buyer. Joe described another obstacle for farmers who were raised on conventional farms, but decide to change to organic methods: "Organic is a knock to Dad. He has a hard time with it. He tries to tell us what to do."

\section{Farmer characteristics}

Age. The organic farmers' mean age was 46 years, with a range from 26 to 70 and a median of 42 . The statewide mean is 53 years (Bureau of the Census, 1992). In addition, the mean length of time in farming was 18 years for this group, which shows that on average these organic farmers went into farming at age 28 . Indeed, only $44 \%$ of these organic farmers were raised on farms, all of which were conventional farms.

Education. The organic farmers varied widely in their levels of educational attainment: of the 23 who responded, $8 \%$ did not finish high school, $4 \%$ were high school graduates, $22 \%$ had some college, $52 \%$ were college graduates, $4 \%$ had an MA, and $8 \%$ had a PhD. They were unlikely to have studied production agriculture while in college: only $9 \%$ of the organic farmers had this emphasis, while the remainder studied history, literature, biology, theology, or another discipline. This supports the literature that suggests alternative views of agriculture exist between people with degrees in production agriculture versus nonagricultural fields (Beus and Dunlap, 1992). Indeed, viewpoints other than production agriculture seem to be influential in the adoption process for these organic farmers.

\section{Farmers' motivations and attitudes}

Why farm? Written responses to "Why are you in farming?" included "it's a challenge" and "for land stewardship." One respondent lightheartedly wrote that "it beats getting a real job!" In-depth interviews allowed farmers to expand on their personal ideas about farming. Andy and Lewis are relative newcomers to farming, having purchased their land 10 to 25 years ago: "I love it. I did other things, but I like doing this" (Andy); "I've always had an interest in agriculture. Over the years, I bought a farm and it was conventional. Then we shifted to organic" (Lewis).

The other interviewed farmers expressed the importance of family heritage and regional identity in farming. Jack says: "I was born into ranching. Born and raised here. I can produce a good life for my kids and wife; and I produce the right kind of food. That is necessary. I know it and I like it." Joe says that "it's a way of life, the way we were raised." As Cal puts it: "I like it better than anything else I've ever done." For his wife, Natalie, it's "tradition. It's our land; our life. We farm for the love of the land. It is 24 hours a day. Farming determines your life: when you eat, the number of children you have, when and if you take a vacation, and so on. It's an occupation and vocation."

Why organic? While the mail surveys delineated general characteristics, the interviews allowed for a deeper investigation of factors that motivate a farmer's decision to adopt organic methods. Many enjoy the challenge of organic farming, as Joe notes: "If somebody tells me that it can't be done, I will prove that it can be done. I'll try all avenues before giving up." Other farmers are more matter-of-fact about their decision to farm organically. Andy says he has "no philosophical reason, it's just the way to do it on this scale. It's a good way to do things. It works here." For Jack, "it is economics. The 1980s were rough times in ag. Interest was high, up to $20 \%$, and you can't survive that. So I had to do something." He chose alternative ranching based on the Holistic Resource Management (HRM) method, and he now produces "natural beef" that is sold in specialized markets. Lewis explains that his change to organic was not so great, since "I was always sustainable; I tried to conserve and improve the land." The farm was almost organic anyway, so he got it certified and eventually "we 
called it that. Really the philosophy was phased in over time."

Activities. To investigate various influences on farmers' daily lives, I asked them about the political, religious, and environmental activities in which they participate. Half belonged to political organizations. While different people may define a political organization differently, by indicating membership in such a group the farmer expresses a personal belief or attitude about the importance of such organizations. Several farmers were very active in local politics and community organizations, such as the school board. Forty-two percent belonged to religious organizations, about half of whom noted that they were "very active" in these organizations. Several farmers enclosed stickers, cards or notes with the returned surveys that illustrated their strong religious beliefs. Nearly all $(93 \%)$ were members of resource conservation organizations, including: Greenpeace, Sierra Club, The Nature Conservancy, The Humane Society, American Farmland Trust, Soil and Water Conservation Society, Audubon Society and various local environmental groups; $57 \%$ said they were very active in these organizations. A few are members of traditional agricultural organizations. Joe and Tina are active in a conventional group called Young Farmers, but she explained that sometimes "there is a clash of ideas. Most farmers say 'do it the way my Dad did it!' I think we should try new ideas! Educational farming should be discussed" to improve the public's knowledge of agriculture.

Sources of information. Almost all the farmers $(96 \%)$ said that they read "a lot," but only $14 \%$ said that they primarily read farm publications. Instead, they used a wide array of reading sources, including: Colorado Farmer/Rancher, Earth First, Fence Post, The Grower, Holistic Range Management, Grass Farmer, Organic Gardening, Mother Earth, New Farm Magazine (no longer published), High Country News, Utne Reader, Water Management, "all Rodale publications," religious magazines, metaphysical and selfawareness books, historical novels, philosophy, the Bible, books about soil science, and books by Wes Jackson, Edward Abbey, and Aldo Leopold. Andy was somewhat embarrassed to admit that Wendell
Berry inspired him, but emphasized that "I'm not an environmentalist. I just try to make the best decision for my place, my farm, and community on the ground here."

Traditional sources of information, such as university-sponsored agricultural research and extension offices, were not considered useful by these farmers. Natalie believes that universities "need to switch research to sustainable agriculture. At all land grant colleges, research is funded by chemical companies. Information from them for organic producers is null and void." According to Joe, "LISA is becoming the norm. University research now pushes 'sustainable agriculture,' which means cutting back on chemicalsdon't do it if you don't need to. That's not organic, but conventional farmers think it is organic." Lewis often reads journals to find out who the experts are on a given topic, then contacts them directly: "I go everywhere for information!"

Perceptions of agriculture, nature, and environmentalists. When asked to describe "alternative agriculture," their responses included: "using nontraditional means," "diversification," "sustainable farming," and "less mechanical." About one-fourth defined it as "organic agriculture." This shows the variation in how organic farmers perceive and define alternative and organic methods. They displayed an understanding of complex ecological terms. Half the surveyed farmers knew the term "agroecology" (see Altieri, 1995), which they defined as "taking care of the environment," "the ecosystem of agriculture," and "sustainable farming." Lewis says that "agroecology is basically what organic is about: agriculture that takes ecosystems into account."

In the interviews, farmers discussed whether they thought humans were more part of nature or more managers over nature. This question proved to be thoughtprovoking and yielded responses that show the complexity of how farmers feel about their land. According to Lewis, "people are part of nature, but just because something in nature is there, it doesn't mean people shouldn't manage it. People should also manage." Jack explained that a ranch is, and should be, an ecosystem because "everything's got to work together." Tina's advice was: "Don't try to change nature. Let it run its course." But her husband, Joe, was thoughtful when he noted that "artificial insemination is against nature, and so is breeding. It is fuzzy. I manage nature. I put cows inside a fence. I have to be a manager. Farmers do specifically." Natalie noted the weather extremes of the eastern Colorado plains and said that "you don't ever manage nature, you have to be part of it."

These organic farmers discussed what an "environmentalist" is and how they personally relate to the environmental movement. Although organic farming tends to be linked to the environmental movement (Merchant, 1992), the interviewed farmers held distinct and often negative views of environmentalists. Jack defined an environmentalist as "someone who is interested in their opinion of the betterment of land, animals, birds, but not necessarily my way of thinking. Some of it is too radical and lopsided. I'm an environmentalist because I want the land and wildlife to be in a better situation than when I took over." He has specifically attended environmentalists' meetings to represent farmers and "to get our point across," because he feels that "city people don't understand agriculture." Lewis believes that "people at the forefront of the environmental movement are frauds. They are for protecting things for the limited few at the expense of the public. We [organic farmers] are environmentalists pushed to the extreme: organic, but we still can't go along with radical environmentalists." Natalie agrees: "There are too many radicals. What is the goal? Do they want continued production, or to eliminate U.S. agricultural production so we need imports? We need balance: then they are helpful! . . . Environmentalists don't understand. If you crack down too much on farmers, they will quit. Can we still feed the world? It is the same with organic: if rules are too rigid, nobody will do it." Andy hates the divisiveness between "organic or not." He explained that "TV people always want a soundbite: 'organic is better.'" He thinks that "organic farming is moving away from hippie operations for philosophical and financial reasons. The trend is just to diversify more." Tina said that "environmentalists don't sit behind a desk! A true one has dirt beneath their fingernails." Joe believes that the relationship between 
Table 6. Characteristics of organic farmers in Colorado.

1. Operational diversity

2. Challenge seeking

3. On-farm changes

4. Businesslike approach

5. No formal agricultural education

6. Love of the land and region

7. Anti-"radical environmentalists"

8. Obstacles perceived

unstable organic markets

confronting conventional traditions

lack of organic information sources

farmers and others must change. He explained that "environmentalists think that farmers are recluses, abusing the environment. Farmers need PR to change public opinion. We need to be more vocal!"

\section{Key Characteristics}

Colorado organic farmers and their farms show a great deal of diversity and change. Although they display individual characteristics, there are general patterns that describe organic farmers in Colorado (Table 6). Eight variables describe these farmers: operational diversity, challenge seeking, on-farm changes, businesslike approach, no formal agricultural education, love of the land and region, anti"radical environmentalists," and obstacles they must face (markets, tradition, and information). These eight characteristics, described below, provide an understanding of the factors influencing organic farmer decisionmaking. To emphasize the variation within the organic community, each of the five case study farmers is rated according to these characteristics (Table 7).

Organic operations show high diversity (variable 1), and each is tailored to the specific local conditions and farmer's expertise. Farm size varies greatly-from 2 to 12,000 acres - and organic farmers produce varied crops and livestock, using complex rotations. The farm types among surveyed farmers included mixed livestock and cropping operations, mixed vegetable and grain operations, pure grain operations, orchards, and ranches.

Surveyed farmers commonly noted that they enjoy the challenge (variable 2) that organic farming provides them. They seem to thrive on being unique and trying new methods. Their individual land-use decisions generally are influenced by personal knowledge and experience, family concerns, and long-term productivity.

Two-thirds of the operations had experienced change (variable 3 ) in recent years, and nearly half the farmers plan more changes in the future. Change is primarily influenced by profitability, family demands, consumer preference, and the availability of land to purchase. Thus far, the farms have especially experienced increased diversification and changes in size. These farmers are currently considering the purchase or rental of more land and the addition of new equipment.

These organic farmers have a businesslike approach (variable 4) to their farm and a positive perception of their financial status, with three-fourths noting they were "quite" or "somewhat" profitable. Understanding consumer demand is key to organic farm success, and many farmers have strong ties to their buyers and maintain close links throughout the growing season. These farmers noted the importance of being a businessperson to guide their capital-intensive farms.

Their education levels vary from graduate degrees to less than a high school diploma. Most (91\%) had no formal agricultural education (variable 5). About half were raised on farms, most of which were conventional operations. Thus, half of the group came into organic farming as agricultural newcomers, while half made the transition from conventional to organic production.

Farmers have varying views of why they are in farming, and why they have adopted organic methods. Both newcomers and long-time residents express a love of the land (variable 6). Complex notions of the relationship between people and nature are expressed, and they see themselves as moderate environmentalists. They have distinct views of the environmental movement, and have strong anti"radical environmentalist" attitudes (variable 7). They see environmental radicals as deepening the divide between conventional and organic agriculture and heightening the misunderstanding between farmers and the public.

There are three main obstacles (variable 8) noted by these organic farmers. First is the difficulty in identifying a stable organic market. Many have experienced problems with unreliable wholesalers and are leery of the current structures. Second, many must confront family traditions based on conventional farming, as their parents have not readily accepted organic methods on the family land. Third, farmers complain that there is a lack of information available on organic methods. These common obstacles seem to have been overcome by farmers who enjoy the challenge of organic farming and thrive on their uniqueness even when their operations are the only organic enterprises in their region.

Through the larger mail survey, I discovered that farmers exhibit these eight characteristics to some degree, and it is useful to display actual farmers within these generalized findings. Using the indepth interviews, I found that each case study farmer embodies a unique collection of these characteristics (Table 7). Andy has a small herb operation, is very businesslike, is from a background outside production agriculture, and has not experienced the obstacles common to many farmers. Joe and Tina operate a highly diverse crop and livestock operation and clearly identify obstacles they have overcome as they are strongly guided by conventional family farming traditions. Lewis has a large, highly diversified vegetable operation, is very businesslike, and has not confronted a traditional agricultural background. Natalie and Cal operate a grain farm that is not highly diverse, but is guided by their facing the challenges of organic farming and their love of the land. Jack runs a holistic ranch operation that is not highly diverse; he believes that radical environmentalists are not able to rectify the problems with modern agriculture, and he is driven by love of the land and the challenge of alternative ranching.

\section{Conclusions}

Data on organic production and consumption are scant, and this form of production is not enumerated in agricultural census publications. U.S. sales of organic foods were estimated at $\$ 174$ million in 1980 , increasing to $\$ 1.25$ billion by 1989 and to over $\$ 3.5$ billion by 1996 (Jacobson et al., 1991; Natural Foods Merchandiser, 1997). Grocery chains increasingly carry 
Table 7. Measuring characteristics of case study organic farmers.

\begin{tabular}{|c|c|c|c|c|c|}
\hline & Andy & Tina/Joe & Lewis & Natalie/Cal & Jack \\
\hline 1. Diversity & high & high & high & low & low \\
\hline 2. Challenge & high & high & medium & high & high \\
\hline 3. Change & high & high & medium & high & medium \\
\hline 4. Business & high & medium & high & medium & medium \\
\hline 5. No formal agricultural & & & & & \\
\hline education & high & high & high & high & medium \\
\hline 6. Love land & medium & high & medium & high & high \\
\hline $\begin{array}{l}\text { 7. Anti-"radical } \\
\text { environmentalists" }\end{array}$ & high & high & high & high & high \\
\hline 8. Obstacles & & & & & \\
\hline unstable markets & low & high & high & high & low \\
\hline confront tradition & low & high & low & high & medium \\
\hline lack information & medium & high & medium & medium & medium \\
\hline
\end{tabular}

organic products, and the trend is for continued growth (Jolly and Norris, 1991). Such increases in both production and consumption, combined with new national regulation, suggest that organic agriculture is expanding. This research illuminates characteristics of farmers who adopted organic methods and the operational variables present on their farms.

Interviews depict the multifaceted array of farmers who individually acted to adopt organic methods and continue to employ strong proactive characteristics to identify markets and find sources of information on organic techniques. Eight characteristics are important in understanding these farmers: diversity, challenge, change, businesslike approach, no formal agricultural education, love of the land, anti-"radical environmentalist"' attitude, and facing obstacles. The open-ended interviews further showed that these organic farmers find that the divisiveness between organic and conventional agriculture is faulty and should be reconsidered by the media, the public and researchers. They express concern that "radical environmentalists" hamper positive communication. Overall, these farmers are proactive and willing to try new ideas. They enjoy the challenge of organic farming because it demands individual initiative, acceptance of risk, and innovative farming techniques.

Implications of this research suggest possible means for encouraging the adoption of organic methods. Personal characteristics influenced the agricultural decisionmaking of the responding organic farmers. But these personal attitudes and characteristics evolve slowly and are not likely to be changed by other people. What can be addressed by researchers and agency personnel, however, are the obstacles these farmers face.

Given the obstacles discovered in this survey, stabilization of organic markets is the first concern of farmers. National organic standards, soon to be implemented, may address this problem, if they provide consumer confidence in organic products. The second obstacle, confronting conventional traditions, is harder to remedy. Perhaps by making organic methods more acceptable in and accessible through mainstream agricultural outreach, the decision to adopt organic would not be perceived as an insult to conventional farmers. Indeed, the organic case study farmers disagreed with the conflict-ridden division between conventional and organic agriculture and felt that more dialogue would lead to improved understanding. The third obstacle, lack of information sources, is also related to these concepts of acceptance. University research should encompass organic farming, and extension should include organic methods in their outreach efforts to aid current and possible future organic farmers. This would foster a sense of belonging that does not now exist. While organic farmers revel in the challenge of adopting new methods, the obstacles they face are often considered insurmountable by conventional farmers. Easing these obstacles, through policy, remore farmers to perceive organic methods as a feasible option. search, and education, could encourage
Acknowledgment. I am grateful to Colorado farmer participants who taught me so much about organic farming, and to J. Bathgate and A. Spearing, without whom this research would not have been published.

\section{References}

1. Allen, P., and C. Sachs. 1993. Sustainable agriculture in the United States: Engagements, silences, and possibilities for transformation. In P. Allen (ed.). Food for the Future: Conditions and Contradictions of Sustainability. John Wiley, New York, NY. p. 139167.

2. Altieri, M. 1995. Agroecology: The Science of Sustainable Agriculture. Westview Press, Boulder, CO.

3. Batte, M., D. Forster, and F. Hitzhusen. 1993. Organic agriculture in Ohio: An economic perspective. J. Production Agric. 6:536-542.

4. Benbrook, C. 1995. Healthy Food, Healthy Farms: Pest Management in the Public Interest. National Campaign for Pesticide Policy Reform, Washington, DC.

5. Beus, C., and R. Dunlap. 1992. The alternative-conventional agricultural debate: Where do agricultural faculty stand? Rural Sociology 57:363-380.

6. Buttel, F., and G. Gillespie. 1988. Preferences for crop production practices among conventional and alternative farmers. Amer. J. Alternative Agric. 3:11-17.

7. Bureau of the Census. 1992. Census of Agriculture. Vol. 1: State and County Data. Part 6: Colorado. U.S. Department of Commerce, Washington, DC.

8. COPA. 1993. Marketing Directory. Colorado Organic Producers Association, Denver, CO.

9. Danbom, D.B. 1991. Romantic agrarianism in twentieth-century America. Agric. History 65:1-12.

10. Dunn, J. 1995. Organic food and fiber: An analysis of 1994 certified production in the United States. Agricultural Marketing Service, U.S. Dept. of Agriculture, Washington, DC.

11. Duram, L. 1997. A pragmatic study of conventional and alternative farmers in Colorado. The Professional Geographer 49:202-213.

12. Duram, L. 1998. Organic agriculture in the US: Current status and future 
regulation. Choices: The Magazine of Food, Farm, and Resource Issues 2:34-38.

13. Jacobson, M., L. Lefferts, and A. Garland. 1991. Safe Food: Eating Wisely in a Risky World. Center for Science in the Public Interest. Living Planet Press, Los Angeles, CA.

14. Jolly, D., and K. Norris. 1991. Marketing prospects for organic and pesticide-free produce. Amer. J. Alternative Agric. 6:174-179.

15. Korsching, P., and T. Hoban. 1990. Relationships between information sources and farmers' conservation perceptions and behavior. Society and Natural Resources 3:1-10.

16. Lockeretz, W. 1997. Diversity of personal and enterprise characteristics among organic growers in the northeastern United States. Biological Agric. and Horticulture 14:13-20.

17. Lockeretz, W., and P. Madden 1987. Midwestern organic farming: A tenyear follow-up. Amer. J. Alternative Agric. 2:57-63.

18. Lockeretz, W., G. Shearer, R. Klepper, and S. Sweeney. 1978. Field crop production on organic farms in the midwest. J. Soil and Water Conservation 33:130-134.

19. Lockeretz, W., G. Shearer, and D. Kohl. 1981. Organic farming in the corn belt. Science 211:540-547.

20. Merchant, C. 1992. Radical Ecology: The Search for a Livable World. Routledge, New York, NY.

21. Miles, M., and A.M. Huberman. 1994. Qualitative Data Analysis. Sage, Thousand Oaks, CA.

22. Natural Foods Merchandiser. 1997. Organic Sales. New Hope Communications, Boulder, CO.

23. Padgitt, S., and P. Petrzelka. 1994. Making sustainable agriculture the new conventional agriculture: Social change and sustainability. In J. Hatfield and D. Karlen (eds.). Sustainable Agricultural Systems. Lewis, Boca Raton, FL. p. 261-285.

24. Salamon, S., R. Farnsworth, D. Bullock, and R. Yusuf. 1997. Family factors affecting adoption of sustainable farming systems. J. Soil and Water Conservation 52:265-271.
25. Smolik, J., and T. Dobbs. 1991. Crop yields and economic returns accompanying the transition to alternative farming systems. J. Production Agric. 4:153-161.

26. Smolik, J., T. Dobbs, and D. Rickerl. 1995. The relative sustainability of alternative, conventional, and reducedtill farming systems. Amer. J. Alternative Agric. 10:25-35.

27. Stanhill, G. 1990. The comparative productivity of organic agriculture. Agric., Ecosystems and Environment 30:1-26.

28. Swanson, L., S. Camboni, and T. Napier. 1986. Barriers to adoption of soil conservation practices on farms. In S. Lovejoy and T. Napier (eds.). Conserving Soil: Insights from Socioeconomic Research. Soil Conservation Society of America, Ankeny, IA. p. 21-132.

29. U.S. Dept. of Agriculture. 1994. National Organic Standards Board: Final recommendations for organic crop production standards. Adopted June 1-4. USDA/AMS/TMD, Washington, DC.

\section{USDA Outlines Improvements in Proposed Organic Standards}

At the most recent meeting of the $\mathrm{Na}$ tional Organic Standards Board, the USDA announced several significant improvements on policy issues for the $\mathrm{Na}$ tional Organic Standards that were among the most controversial of the first proposed standards. Keith Jones, Director of the USDA's National Organic Program, outlined improvements in standards for livestock, synthetic materials, inert ingredients in pesticide formulations, and ecolabeling. Important provisions include a $100 \%$ organic feed requirement; a ban on antibiotic use in livestock; a requirement for access to the outdoors for all animals and pasture for all ruminants, with some limited exceptions; NOSB authorization for all approved synthetic materials; a prohibition on all List 2 EPA inerts and all List 3 inerts unless specifically approved by the NOSB; and no restrictions on label claims other than the organic claim.

The USDA will seek a one-time authorization to cover the cost of the first round of certifier accreditation, which will enable small, private certifiers to work in the national program. It is also negotiating a contract with the Organic Materials Review Institute to conduct the necessary technical reviews of materials being considered for the National List of allowable synthetics in organic production. The NOSB has also brokered a tentative compromise between the USDA and the private certifier community on provisions for termination of certification. The arrangement would allow private certifiers, after finding a serious violation of standards and conducting an internal appeal process, to revoke the letter of certification through which it authorized the offending operation to use its seal. The operation can elect to appeal the certifier's decision to the USDA Sec- retary, who retains final authority to terminate certification.

Kathleen Merrigan, the Wallace Institute's Senior Analyst, is a member of the NOSB.

\section{Organic Practices Can Reduce Groundwater Contamination}

The adoption of organic soil practices can effectively reduce nitrate contamination of groundwater while maintaining yields and improving overall soil quality, according to a 15-year study by the Rodale Institute. The research highlights an organic solution that could reduce the harmful effects of agricultural groundwater pollution and its contamination of surrounding waters. The study also found that organic management increased soil fertility, improved water filtration and holding capacity, reduced erosion, and increased crop productivity, especially during dry years. 


\title{
Evaluation of farmers' perceptions of soil quality indicators
}

\author{
Mark A. Liebig and John W. Doran
}

Abstract. Understanding farmers' knowledge of soil quality and health is essential to ensure transfer of appropriate technology for on-farm assessments. The objective of this study was to evaluate farmers' knowledge of soil quality by comparing their perceptions of soil conditions for "good" and "problem" soils on their farms with values of soil quality indicators as determined by established assessment protocol. Twenty-four conventional and organic farmers throughout eastern Nebraska were paired within regions of similar climate, topography, and soil type and their perceptions of soil quality indicators were queried using a written questionnaire. Questionnaire data were compared directly to values of soil quality indicators and perception accuracy indices were calculated. Overall, perception accuracy of soil quality indicators did not differ between conventional and organic farmers. Farmers' perceptions of soil quality indicators tended to be more accurate for "good" soils as compared to "problem" soils. Indicators that were incorrectly estimated at a frequency greater than $33 \%$ included available nitrogen and phosphorus, soil color, degree of compaction, and infiltration rate. Despite this, farmers' perceptions were correct or nearly-correct over $75 \%$ of the time for the majority of indicators evaluated in the study. Evaluation of social and managerial factors indicated that perception accuracy of soil quality indicators declined as the time of on-farm tenure increased. Results from this study indicate that agriculturists should seek out farmers' knowledge of soil characteristics as a first iteration to pointscale evaluation of soil quality.

Key words: farmer knowledge, point-scale evaluation.

Recent work in soil quality has sought to identify assessments for evaluating soil condition within contexts of productivity, environmental quality, and animal health (Acton and Gregorich, 1995; Doran and

Mark A. Liebig is Graduate Research Assistant, Dept. of Agronomy, University of Nebraska, Lincoln, NE 68583 (mliebig@unlinfo.unl.edu); John W. Doran is Soil Scientist, USDA-ARS, University of Nebraska, Lincoln, NE 68583 (jdoran@unlinfo.unl.edu).

Contribution from the Nebraska Agric. Exp. Stn., Journal Series No. 12065.

Mention of commercial products and organizations in this publication is solely to provide specific information. It does not constitute endorsement by the University of Nebraska or USDA-ARS to the exclusion of other products or organizations not mentioned.

Volume 14, Number 1, 1999 to activities that can be conducted within a normal work routine, such as working the soil with agricultural implements and watching crop development throughout the growing season (McCallister and Nowak, 1998). These activities, often based on perceptions of natural systems, are inherently qualitative because they utilize words as descriptors (Harris and Bezdicek, 1994). Furthermore, such assessments are interpreted within ecological and social realities of local environments, thereby limiting extrapolation to different regions (Romig et al., 1995).

The apparent difference between scientists and farmers in soil quality assessment is a challenge to those who seek to increase awareness among agricultural producers regarding management impacts on soil quality. Transfer of appropriate technology in the form of tools and methodologies for assessing soil quality is critical to meeting this challenge. Requisite to this, however, is knowledge of how farmers' perceptions of soil quality indicators relate to standard quantifiable assessments.

Previous work relating farmers' perceptions to quantifiable assessments has been conducted through the Wisconsin Soil Health Program (Harris and Bezdicek, 1994). The program evolved from informal dialogues with farmers to the development of an interpretive framework that recognizes descriptive and analytical properties of soil and related systems for soil quality assessment (Romig et al., 1995). This interpretive framework provided the foundation for development of a soil health scorecard (Romig et al., 1996), and established guidelines for evaluating farmer knowledge of soil quality and health (Garlynd et al., 1994, 1995). smell (Romig et al., 1995). Moreover, sessments by farmers are largely limited 
Work by the Wisconsin group has been vital to understanding how farmers perceive and describe soil quality indicators. For example, in a survey of conventional, organic, and biodynamic farmers, Garlynd et al. (1994) found perceptions of highquality soils to be associated with comments that such soils were "deeper, darker, easier to plow, worked up more easily in the spring, sponged up and held more water, dried out sooner, broke down corn stalks more rapidly in the fall, had higher organic matter content and less erosion, had greater numbers and more species of worms, and had a recognizably sweet, fresh-air smell." Comments such as these are useful in developing extension materials for soil quality. In fact, the Soil Quality Institute (USDA-NRCS) has used the approach by the Wisconsin group to develop soil quality assessment cards based on farmers' knowledge of soil quality within specific eco-regions (Soil Quality Institute, 1997).

Correlation of farmers' comments to different types of soils is a useful first step in understanding their knowledge of soil quality. However, there is a need to transpose farmers' knowledge of soil quality to achieve a better understanding of the accuracy of their perceptions of specific indicators. Such information is essential to provide agriculturists with the knowledge of where farmers' strengths and weaknesses lie in estimating the condition of soils they manage.

In a sample of 745 Wisconsin corn farmers, McCallister and Nowak (1998) found farmers perceptions of surface soil characteristics of topsoil depth, soil texture, and organic matter content to be accurate less than half the time when compared to 1987 National Resources Inventory (NRI) sampling points. Furthermore, accurate perceptions of soil characteristics were found to decrease markedly as the soil profile depth increased.

The objective of this study was to evaluate the accuracy of farmers' perceptions of soil quality indicators by comparison to present measured soil conditions. To do this we gathered farmers' perceptions of soils they manage through a written questionnaire containing narrative descriptions of selected soil quality indicators. We then compared their perceptions to what was

Table 1. Background information for organic and conventional farmers in study.

\begin{tabular}{lcc}
\hline \multicolumn{1}{c}{ Variable } & Organic & Conventional \\
\hline Number of years farming & 25 & 20 \\
Years of school completed & 15 & 13 \\
Farm size (ha) & 211 & $545^{*}$ \\
Percent of land owned & 77 & $37^{*}$ \\
$\mathrm{n}$ & 12 & 12 \\
\hline
\end{tabular}

* Mean values for a variable significantly different at $\mathrm{P} \leq 0.05$.

assumed to exist by using established approaches and criteria for assessing soil quality. To aid in interpreting results, managerial and social data were collected from each farmer through personal interviews.

\section{Materials and Methods}

\section{Selection of study participants}

The subject population included two groups of farmers: one group employing organic management methods for crop production, the other using standard conventional production methods. Surveys have indicated the importance organic farmers place on soil quality in their management plans (Lockeretz et al., 1981). This importance is also reflected in the writings of practitioners of organic farming who express a commitment to soil conservation and enhancement of soil biological activity (Howard, 1947; Bender, 1994). Consequently, organic and conventional farmers were chosen based on a conjecture that the two groups of farmers would have different levels of perception accuracy of soil quality indicators. Only full-time farmers in eastern Nebraska were considered potential participants because of their proximity to the University of Nebraska-Lincoln campus.

Study participants were selected in the spring of 1996. A static-group comparison sampling design was used (Judd et al., 1991, p. 105-107). Fourteen organic farmers were randomly chosen from a list of current members of the Organic Crop Improvement Association (Nebraska Chapter, No. 1). A letter was sent to each selected organic farmer outlining the details of the study with regard to its degree of involvement, expectations, and time required. Approximately two weeks after sending the letter, each farmer was called by telephone and consent for participation in the study was confirmed. Of the fourteen organic farmers selected for the study, twelve chose to participate.

As there was no list available for conventional farmers, they were chosen from contacts provided by University of $\mathrm{Ne}$ braska Cooperative Extension personnel in regions specific to the location of each organic farmer, thereby making it a nonrandom sample of twelve potential participants. Criteria for selection of conventional farmers were specified by letter to extension personnel as follows:

1. Profit and production maximization are considered to be primary goals of farming.

2. Technological innovations are considered an appropriate measure of agricultural progress.

3. Larger farm units and improved labor efficiency are considered the key to continued agricultural modernization and farm profitability.

Stated in terms of management systems, conventional farmers were described as using off-farm inputs to sustain soil fertility and protect crops from pests, having low crop diversity, not having livestock, and as common participants in government price support programs (Stauber et al., 1995).

As with organic farmers, letters were sent to conventional farmers and followup telephone calls were made. All conventional farmers selected for the study chose to participate, bringing the total sample size to 24 . This sample size reflected the maximum number of participants allowable given the resources and time available for the study. Background information for organic and conventional farmers is presented in Table 1.

\section{Collection of farmers' perceptions of soil quality indicators}

Farmers participating in the study were interviewed individually from July 
through September 1996. In most cases, organic and conventional farmers paired within a region were surveyed within a day of each other.

Farmers' perceptions of soil quality indicators were collected using a written questionnaire that was adapted from the Wisconsin Soil Health Scorecard (Romig et al., 1996). The questionnaire asked farmers to estimate the condition of fourteen soil properties as they existed at the time of the survey. Soil properties included soil texture, soil color, topsoil depth, bulk density (degree of compaction), infiltration rate, available waterholding capacity, soil structure, available nitrogen and phosphorus, soil organic matter, soil $\mathrm{pH}$, electrical conductivity (salinity), earthworm activity, and soil smell (as an indicator of aerobic microbial activity). Questions were closed-ended with ordered-choice response categories (Table 2 ). Ordinal scales were used for all response categories except for estimates of available nitrogen, phosphorus, soil organic matter, and soil $\mathrm{pH}$, where interval scales were used (Judd et al., 1991; p. 62-64).

To collect a wide range of perceptions, estimates were given for "good" and "problem" soils as identified by each farmer. No specific instructions were given to farmers in selecting either soil; what was considered a "good" or "problem" soil was entirely up to each participant. [Note: The use of the word "problem" in place of "poor" was deliberate. While pretesting the study in 1995 the word "poor" was used in the questionnaire. We found that farmers had a difficult time narrowing down their choices to one poor soil. When posed with the word "problem", it seemed that farmers could more easily identify a single soil on their farm. As a result, we chose to use the word "problem" in the main study.]

The questionnaire instructed farmers to draw upon their experience and knowledge of each soil, and to consider visual observations of soil and crops over time, experiences during tillage, and results from analytical soil tests. Estimates for most properties were restricted to the "plow layer" (0 to $30.5 \mathrm{~cm}$ ).

Each participant filled out the written questionnaire within their personal residence, office, or in a nearby farm building.

Table 2. Questions and response categories used to estimate the condition of 'good' and 'problem' soils by study participants.

$$
\text { -PHYSICAL PROPERTIES }
$$

What would you estimate the texture of this soil to be?

1. Clay, silty clay, or silty clay loam.

2. Loam or clay loam.

3. Silt or silt loam.

4. Sandy clay or sandy clay loam.

5. Sand, loamy sand, or sandy loam.

When this soil is moist, what color is it?

1. Yellow, tan, or light gray.

2. Brownish yellow, pale brown, or light brownish gray.

3. Red, gray, or brown.

4. Dark yellowish brown, dark grayish brown, or dark gray.

5. Dark brown, very dark gray, or black.

What would you estimate the topsoil depth of this soil to be?

1. There is no topsoil. Subsoil is exposed.

2. Topsoil is less than 1 foot in depth.

3. Topsoil is between 1 and 2 feet in depth.

4. Topsoil is greater than 2 feet in depth.

About what degree of compaction best describes this soil?

1. Soil is very compact, difficult to get into, stubborn hardpan present.

2. Soil packed firm, moderately difficult to get into, hardpan present.

3. Soil packed down, thin hardpan or plow layer.

4. Soil moderately loose, hardpan barely noticeable.

5. Soil is loose, no hardpan present.

At approximately what rate would you estimate water enters this soil?

1. Water does not soak in, sits on surface or runs off.

2. Little water soaks in, most runs off.

3. Water soaks in slowly, some runoff after heavy rain.

4. Water soaks in quickly, little runoff after heavy rain.

5. Water soaks in immediately, no runoff or ponding.

What would you estimate the water-holding capacity of this soil to be?

1. Soil dries out very fast, droughty.

2. Soil dries out moderately fast, drought prone in dry weather.

3. Soil dries out moderately slow, a decent buffer in dry weather.

4. Soil holds moisture well, an excellent buffer in dry weather.

What type of structure best describes this soil?

1. Very cloddy with big chunks.

2. Cloddy with smaller chunks.

3. Crumbly and granular.

4. Dusty and powdery.

(Continued on next page)

In most cases, questionnaires were completed within 20 minutes, at which time they were returned to the principal investigator and placed in a portable locking file cabinet for later coding and analysis.

\section{Field and laboratory evaluations}

Site establishment. Sites were established and field evaluations were conducted the same day that participants completed the questionnaire. Based on specific location directions provided by each participant, three adjacent rectangular plots were established to serve as pseudo-replicates within each "good" and "problem" soil. Plot dimensions were $3.7 \mathrm{~m}$ long by the width of the planter $(3.9,4.6,5.5,6.1$, 7.3 , or $9.1 \mathrm{~m}$ ). In areas of alfalfa, drilled soybean, mixed grass, or fallow, plot dimensions were 3.7 by $3.7 \mathrm{~m}$. Complete site descriptions are presented Table 3.

Field evaluations. Within each replicate, one aluminum cylinder $(12.7 \mathrm{~cm}$ height by $14.9 \mathrm{~cm}$ i.d.) was installed to 
Table 2. Questions and response categories used to estimate the condition of 'good' and 'problem' soils by study participants. (cont'd)

CHEMICAL PROPERTIES - . . . . . . . . . . . . .

Approximately how much nitrogen is in this soil?
1. 0 - $25 \mathrm{lbs}$ N/acre.
2. $26-50 \mathrm{lbs}$ N/acre.
3. 51 - $75 \mathrm{lbs}$ N/acre.
4. 76 - $100 \mathrm{lbs}$ N/acre.

Approximately how much phosphorus is in this soil?

1. 0 - $15 \mathrm{lbs}$ P/acre.

2. 16 - $30 \mathrm{lbs}$ P/acre.

3. 31 - $45 \mathrm{lbs}$ P/acre.

4. 46 - $60 \mathrm{lbs}$ P/acre.

5. Greater than $60 \mathrm{lbs}$ P/acre.

About what percentage of organic matter is in this soil?

1. Less than $2 \%$.

2. Between $2.1 \%$ and $4 \%$.

3. Between $4.1 \%$ and $6 \%$.

4. Between $6.1 \%$ and $8 \%$.

5. Greater than $8 \%$.

What would you estimate the $\mathrm{pH}$ of this soil to be?

1. Strongly acid ( $\mathrm{pH}$ less than 5.5).

2. Moderately acid ( $\mathrm{pH}$ between 5.6 and 6.5).

3. Neutral ( $\mathrm{pH}$ betwèen 6.6 and 7.5).

4. Moderately alkaline ( $\mathrm{pH}$ between 7.6 and 8.5 ).

5. Strongly alkaline ( $\mathrm{pH}$ greater than 8.5).

Approximately what salinity (salt) level best describes this soil?

1. Non saline.

2. Slightly saline.

3. Moderately saline

4. Strongly saline.

About how much earthworm activity would you estimate in this soil?

1. No activity. No worm holes or castings present.

2. Some activity. Few worm holes or castings present.

3. Much activity. Many worm holes or castings present.

What does this soil smell like?

1. Soil has a definite sour, putrid, or chemical smell.

2. Soil has a slight sour, putrid, or chemical smell.

3. Soil has no odor. Has a mineral smell.

4. Soil has a slight earthy smell.

5. Soil has an earthy, sweet, fresh smell.

$7.6 \mathrm{~cm}$ and used for infiltration rate measurements. For row crops, sampling positions within separate replicates were three row locations of wheel tracked interrow, non-wheel tracked interrow, and row. In non row-crop areas, sampling positions were selected randomly. Infiltration rate was determined by measuring the time required for $2.5 \mathrm{~cm}$ (1.0 in) of water to disappear from the retaining cylinder. The infiltration rate of a second $2.5 \mathrm{~cm}$ of water was measured if the first infiltration time was less than $30 \mathrm{~min}$. Antecedent soil water content for the 0 to $7.6 \mathrm{~cm}$ depth was measured beside each aluminum cylinder.

Topsoil was considered to possess mollic colors of 10YR 3/3 or darker (Soil Survey Staff, 1996). Using this standard, topsoil depth was determined by assessing color changes within the soil profile using three randomly collected samples per replicate with a JMC "Backsaver" $1.8 \mathrm{~cm}$ (i.d.) step-down probe.

Semi-quantitative soil quality indica- tors were evaluated by digging a hole 0.3 by $0.3 \mathrm{~m}$ to a depth of $0.5 \mathrm{~m}$ with a spade in the second replicate of each site. All extracted soil was placed directly adjacent to the hole. Earthworm activity was assessed by counting worms in the extracted soil and observing burrows along the wall of the hole. Although this physical method for assessing earthworm activity was not adequate for species such as Lumbricus terrestris (Blair et al., 1996), it was a useful evaluation for the level of accuracy desired.

Soil structure, color, and smell, were determined at 0 to $7.6 \mathrm{~cm}$ from soil removed from a vertical slice of the hole. Soil structure was determined using classification guidelines of shape, size, and grade of soil peds as outlined by Soil Survey Division Staff (1993). Soil color was determined from a moist sample using a Munsell system color chart (Soil Survey Division Staff, 1993). Soil smell was assessed by inhaling the atmosphere surrounding a handful of soil.

Laboratory evaluations. Soil sampling for laboratory evaluations was conducted concurrently with field evaluations. Within each replicate, one composite sample of six cores was collected to $30.5 \mathrm{~cm}$ using a $1.8 \mathrm{~cm}$ (i.d.) step-down probe. At all sites, composite samples were considered to be representative of the whole area of each replicate. In row-crop areas, cores were collected from each row location in proportions appropriate to the observed traffic patterns and row spacings in the field. In non rowcrop areas, cores were collected randomly. Each sample was saved in a double-lined plastic bag, placed in cold storage at $5^{\circ} \mathrm{C}$, and analyzed within one week of collection.

Samples were processed by sieving through a $4.75 \mathrm{~mm}$ sieve at field moisture content. Electrical conductivity and soil $\mathrm{pH}$ were estimated from a 1:1 soil-water mixture with $10 \mathrm{~g}$ of air-dried soil (Dahnke and Whitney, 1988; Eckert, 1988). Soil nitrate was estimated from 1:10 soil-KCl $(2 \mathrm{M})$ extracts using cadmium reduction followed by a modified Griess-Ilosvay method (Keeney and Nelson, 1982). Extractable phosphorus was determined by Bray-1 for soils with $\mathrm{pH}$ less than or equal to 7.0. For soils of $\mathrm{pH}$ greater than 7.0, extractable phosphorus was determined by 
Table 3. Site descriptions for farmer-identified 'good' and 'problem' soils.

\begin{tabular}{|c|c|c|c|c|c|c|c|}
\hline Survey & Soil & Management & Crop & Irrigation & Planter width & Row width & Soil series and subgroup name \\
\hline & & & & & (m) & $(\mathrm{cm})$ & \\
\hline \multirow[t]{2}{*}{1} & Good & Organic & Popcorn & Gravity & 4.6 & 76 & Holder, Udic Argiustoll \\
\hline & Problem & & Alfalfa & Dryland & & & Holder, Udic Argiustoll \\
\hline \multirow[t]{2}{*}{2} & Good & Conventional & Corn & Pivot & 4.6 & 76 & Hastings, Udic Argiustoll \\
\hline & Problem & & Corn & Pivot & 4.6 & 76 & Hastings, Udic Argiustoll \\
\hline \multirow[t]{2}{*}{3} & Good & Organic & Corn & Gravity & 6.1 & 76 & Hastings, Udic Argiustoll \\
\hline & Problem & & Corn & Gravity & 6.1 & 76 & Hastings, Udic Argiustoll \\
\hline \multirow[t]{2}{*}{4} & Good & Conventional & Corn & Gravity & 9.1 & 76 & Hastings, Udic Argiustoll \\
\hline & Problem & & Corn & Gravity & 9.1 & 76 & Butler, Abruptic Argiaquoll \\
\hline \multirow[t]{2}{*}{5} & Good & Organic & Soybean & Dryland & 4.6 & 76 & Hastings, Udic Argiustoll \\
\hline & Problem & & Alfalfa & Dryland & & & Geary, Udic Argiustoll \\
\hline \multirow[t]{2}{*}{6} & Good & Conventional & Corn & Gravity & 9.1 & 76 & Hastings, Udic Argiustoll \\
\hline & Problem & & Soybean & Pivot & 9.1 & 76 & Hastings, Udic Argiustoll \\
\hline \multirow[t]{2}{*}{7} & Good & Organic & Corn & Pivot & 4.6 & 76 & Hastings, Udic Argiustoll \\
\hline & Problem & & Corn & Pivot & 4.6 & 76 & Hastings, Udic Argiustoll \\
\hline \multirow[t]{2}{*}{8} & Good & Conventional & Soybean & Gravity & 6.1 & 76 & Crete, Pachic Argiustoll \\
\hline & Problem & & Soybean & Gravity & 6.1 & 76 & Crete, Pachic Argiustoll \\
\hline \multirow[t]{2}{*}{9} & Good & Organic & Corn & Dryland & 3.9 & 97 & Muir, Cumulic Haplustoll \\
\hline & Problem & & Corn & Dryland & 3.9 & 97 & Muir, Cumulic Haplustoll \\
\hline \multirow[t]{2}{*}{10} & Good & Conventional & Corn & Gravity & 6.1 & 76 & Muir, Cumulic Haplustoll \\
\hline & Problem & & Corn & Pivot & 6.1 & 76 & Muir, Cumulic Haplustoll \\
\hline \multirow[t]{2}{*}{11} & Good & Organic & Soybean & Gravity & 4.6 & 76 & Kenesaw, Typic Haplustoll \\
\hline & Problem & & Soybean & Gravity & 4.6 & 76 & Hord, Pachic Haplustoll \\
\hline \multirow[t]{2}{*}{12} & Good & Conventional & Corn & Pivot & 9.1 & 76 & Hastings, Udic Argiustoll \\
\hline & Problem & & Corn & Pivot & 9.1 & 76 & Holder, Udic Argiustoll \\
\hline \multirow[t]{2}{*}{13} & Good & Organic & Alfalfa & Dryland & & & Gibbon, Typic Haplaquoll \\
\hline & Problem & & Soybean & Dryland & 6.1 & 76 & Gibbon, Typic Haplaquoll \\
\hline \multirow[t]{2}{*}{14} & Good & Conventional & Corn & Dryland & 7.3 & 91 & Gibbon, Typic Haplaquoll \\
\hline & Problem & & Alfalfa & Dryland & & & Wann, Fluvaquentic Haplustoll \\
\hline \multirow[t]{2}{*}{15} & Good & Organic & Soybean & Dryland & 3.9 & 97 & Judson, Cumulic Hapludoll \\
\hline & Problem & & Fallow & Dryland & & & Ponca, Typic Hapludoll \\
\hline \multirow[t]{2}{*}{16} & Good & Conventional & Corn & Gravity & 5.5 & 91 & Grigston, Fluventic Haplustoll \\
\hline & Problem & & Corn & $\begin{array}{l}\text { High-volume } \\
\text { gun }\end{array}$ & 5.5 & 91 & Zook, Cumulic Haplaquoll \\
\hline \multirow[t]{2}{*}{17} & Good & Organic & Soybean & Dryland & 3.9 & 97 & Gibbon, Typic Haplaquoll \\
\hline & Problem & & Corn & Dryland & 3.9 & 97 & Yutan, Mollic Hapludalf \\
\hline \multirow[t]{2}{*}{18} & Good & Conventional & Soybean & Pivot & 7.3 & 91 & Muir, Cumulic Haplustoll \\
\hline & Problem & & Corn & Pivot & 7.3 & 91 & Zook, Cumulic Haplaquoll \\
\hline \multirow[t]{2}{*}{19} & Good & Organic & Alfalfa & Dryland & & & Sharpsburg, Typic Argiudoll \\
\hline & Problem & & Alfalfa & Dryland & & & Sharpsburg, Typic Argiudoll \\
\hline 20 & Good & Conventional & Soybean & & & & \\
\hline & & & (drilled) & Pivot & 4.6 & & Gibbon, Typic Haplaquoll \\
\hline & Problem & & Soybean & & & & \\
\hline & & & (drilled) & Dryland & 4.6 & & Wann, Fluvaquentic Haplustoll \\
\hline 21 & Good & Organic & Corn & Dryland & 3.9 & 97 & Hobbs, Cumulic Haplustoll \\
\hline & Problem & & Corn & Gravity & 3.9 & 97 & Hord, Pachic Haplustoll \\
\hline 22 & Good & Conventional & Corn & Pivot & 6.1 & 76 & Hastings, Udic Argiustoll \\
\hline & Problem & & Corn & Gravity & 6.1 & 76 & Holder, Udic Argiustoll \\
\hline 23 & Good & Organic & Corn & Gravity & 5.5 & 91 & Cozad, Fluventic Haplustoll \\
\hline & Problem & & Mixed & & & & \\
\hline & & & grass & Dryland & & & Gates, Typic Ustorthent \\
\hline 24 & Good & Conventional & Corn & Gravity & 9.1 & 76 & Cozad, Fluventic Haplustoll \\
\hline & Problem & & Corn & Gravity & 9.1 & 76 & Cozad, Fluventic Haplustoll \\
\hline
\end{tabular}


extraction with sodium bicarbonate (Olson and Sommers, 1982). Total carbon was determined by dry combustion using a CNS analyzer (Model NA1500, Carlo Erba Strumentazione, Milan, Italy). Organic carbon was determined by subtraction of carbonate, which was assessed by measurement of evolved $\mathrm{CO}_{2}$ by gas chromatography after reaction with excess $\mathrm{HCl}$ $(1 \mathrm{~N})$ stabilized with $\mathrm{FeCl}_{2}$. Organic matter content was calculated assuming $58 \%$ of organic matter is composed of organic carbon (Nelson and Sommers, 1982).

Gravimetric data were converted to a volumetric basis using field-measured soil bulk density (Blake and Hartge, 1986). Particle-size distribution was determined using the hydrometer method (Gee and Bauder, 1986). Available water-holding capacity (i.e., volume percent of water retained between -33 and $-1500 \mathrm{kPa}$ ) was estimated from soil-water retention curves based on particle-size distribution, bulk density, and percent organic matter (Gupta and Larson, 1979). A lower "field capacity" pressure step of $-10 \mathrm{kPa}$ was used for soils in sandy loam and loamy sand textural classes. All data were expressed on an oven-dry basis.

\section{Matching field and laboratory data to farmers' perceptions}

All field and laboratory data were put into classes equivalent to the response categories on the written questionnaire. Data for nitrogen and phosphorus, soil organic matter, soil $\mathrm{pH}$, and topsoil depth were placed directly into classes based on their analytically-determined values. Soils were placed into appropriate textural classes based on their content of sand, silt, and clay. Classes for soil color were determined by matching hue, value, and chroma of each soil to the associated color name. Classes for soil smell and soil structure were determined using the descriptive categories provided in the questionnaire. Most soils possessed a massive structure which made differentiation of individual structural units difficult.

Specific guidelines for class placement were required for salinity, available waterholding capacity, earthworm activity, degree of compaction, and infiltration rate. For soils with silt loam to clay loam textures, electrical conductivity ranges of 0 to $1.3,1.4$ to $2.5,2.6$ to 5.0 , and $\geq 5.1 \mathrm{dSm}^{-1}$ were associated with salinity classes of non-saline, slightly saline, moderately saline, and strongly saline, respectively (after Dahnke and Whitney, 1988). Salinity classes for soils with different textures are reviewed by Smith and Doran (1996). Available water-holding capacity ranges of $<10 \%, 10$ to $14.9 \%, 15$ to $19.9 \%$, and $>20 \%$ by volume were considered to be associated with soils that dried very fast, moderately fast, moderately slow, or held moisture well (McKeague et al., 1986).

Earthworm activity was characterized using three arbitrary classes. If earthworms could not be found in the extracted soil and no burrows were present along the wall of the hole, the soil was placed in a low earthworm activity class. If more than three earthworms were present in the extracted soil and burrows were found along the wall of the hole, the soil was placed in a high earthworm activity class. Soils possessing conditions intermediate between the low and high activity classes were placed in a moderate activity class. The low, moderate, and high activity classes corresponded to response categories of "No Activity," "Some Activity," and "Much Activity," respectively.

Soils were placed in one of five compaction classes based on bulk density guidelines developed by Grossman et al. (1996) and are presented in Liebig and Doran (1998). The guidelines assume that lower soil bulk density is associated with a less compact soil condition. Each class corresponded directly to the number of the response category on the written questionnaire.

Permeability ranges were used for infiltration rate to place soils in one of five classes for the first and second $2.5 \mathrm{~cm}$ of water (Soil Survey Division Staff, 1993) and are presented in Liebig and Doran (1998). Ranges were relevant to climatic conditions in eastern Nebraska; every year a $2.5 \mathrm{~cm}$ rainfall of 30 minute duration is expected (Hershfield, 1961). If only 2.5 $\mathrm{cm}$ of water was applied, the appropriate class was used. If two applications of water were conducted and the classes for the first and second $2.5 \mathrm{~cm}$ of water were not the same, the higher of the two classes was selected provided all of the water from the second $2.5 \mathrm{~cm}$ had infiltrated. In cases where the second $2.5 \mathrm{~cm}$ had not infiltrated (due to time restrictions in conducting the assessment), the lower of the two classes was selected. As with compaction, each class corresponded directly to the number of the response category on the written questionnaire.

\section{Calculation and analysis of perception scores}

After field and laboratory data were matched to questionnaire responses, perception scores were calculated for each farmer's "good" and "problem" soil. In doing this, field and laboratory data were assumed to be correct. Scores were calculated as follows: one point was given for each question with a correct perception (response category matched data class), one-half point was given for each question with a nearly-correct perception (response category off by one data class), and zero points were given for questions with incorrect perceptions (response category off by more than one data class). An exception to this scoring system was used with soil texture for nearly-correct and incorrect perceptions. One-half point was given if the perceived soil texture was adjacent to the data class soil texture on the textural triangle. Zero points were given if the perceived soil texture was not adjacent to the data class soil texture on the textural triangle.

Perception accuracy scores were added for physical, chemical, and biological properties and summed across all properties to give a total score. Scores were compared between conventional and organic farmers using LSD at $\mathrm{P} \leq 0.05$ (SAS Institute, 1990).

\section{Collection of social and managerial characteristics}

Managerial and social characteristics considered to influence perception accuracy of soil quality indicators were collected in face-to-face interviews with participants immediately prior to administering the written questionnaire. Characteristics chosen as explanation variables were selected based on interviews with farmers during the pretesting phase of the project.

Participants were asked how many acres they farmed, and of that, how many they owned. Farmers were also asked how 
many years of school they had completed, the number of years they had spent on their current farm, and the number of generations of their family farmed the same farm.

Frequency of direct contact with crops and soils was queried. Farmers were asked how often they physically walked their fields during the growing season with the intent of observing their crop. The same question was asked for soil. A three-point Likert scale was used to record responses to both questions $(1=$ never; 2 = occasionally; $3=$ often). Results were summarized in an index using numerical values of responses.

Information on analytical and descriptive soil quality assessments was collected. Farmers were asked if they used traditional analytical soil tests, and if so, how often. Results were summarized into an index ( $0=$ does not soil test; $1=$ soil test more than five years apart; $2=$ soil test every two to five years; $3=$ soil test every year). Frequency of descriptive soil tests were determined by asking farmers how often they made assessments for fourteen different soil characteristics (residue decomposition rate, soil smell, earthworm counts, soil temperature, soil moisture, topsoil depth, compaction, infiltration rate, water retention, soil structure, soil texture, crusting, aeration, and soil color). Responses were also summarized into an index by giving one point for each assessment conducted at least once a year.

To investigate possible associations between perception accuracy of soil quality indicators and social and managerial characteristics, linear regressions were run between perception scores for "good" and "problem" soils and selected characteristics. Pearson correlation coefficients were determined for each regression. Perception scores for "good" and "problem" soils were also arranged in ascending order and means were calculated for three groups having low (lowest eight), medium (middle eight), and high (highest eight) perception scores. Means for social and managerial characteristics associated with each group were then determined and compared using LSD at $\mathrm{P} \leq 0.05$.

\section{Results}

There was no difference in perception accuracy scores between conventional and organic farmers when summed across all soil quality indicators for both "good" and "problem" soils (Table 4). Furthermore, no differences in perception accuracy scores were observed between the two groups for indicators grouped within physical, chemical, and biological properties. Two differences in perception accuracy did exist, however, for individual indicators. Organic farmers had higher perception accuracy scores than conventional farmers for levels of available phosphorus on "good" soils $(\mathrm{P} \leq 0.01)$. On "problem" soils, organic farmers possessed higher perception accuracy scores than conventional farmers for soil texture $(\mathrm{P} \leq 0.05)$.

Overall, perceptions of soil quality indicators tended to be more accurate for "good" soils as compared to "problem" soils (Table 5). Correct perceptions for indicator groups within physical, chemical, and biological properties averaged 47 , 40 , and $42 \%$, respectively, on "good" soils. Average values for the same groups on "problem"' soils were 33,35 , and $32 \%$.

Correct perceptions of soil quality indicators were $50 \%$ or greater for soil color, topsoil depth, water-holding capacity, soil structure, soil organic matter, and salinity on "good" soils (Table 5). On "problem" soils, only soil texture and salinity were perceived correctly at a frequency of $50 \%$ or more. Eleven of fourteen soil quality indicators were perceived correct or nearly-correct more than $75 \%$ of the time on "good" soils. In fact, all perceptions for soil structure were correct or nearlycorrect on "good" soils. Similarly, on "problem" soils, nine of fourteen indicators were perceived correct or nearly-correct more than $75 \%$ of the time, with soil texture and soil organic matter perceived correct or nearly-correct all of the time.

Three soil quality indicators were associated with a high frequency of incorrect perceptions on "good" soils. Infiltration rate, nitrogen, and phosphorus were incorrectly perceived on "good" soils 33,63 , and $42 \%$ of the time, respectively. Indicators on "problem" soils with $33 \%$ or more incorrect perceptions included soil color (42\%), degree of compaction (33\%), infiltration rate $(50 \%)$, and phosphorus (54\%).

Significant associations between perception accuracy scores and social and managerial characteristics were observed only for "good" soils where perception accuracy of soil quality indicators was negatively correlated with the number of years spent on the farm (Table 6). Accordingly, the high perception score group had spent significantly fewer years on the farm as compared to the low perception score group. Results from all other correlations or mean comparisons for "good" soils were not significant. Despite this, trends in the data did exist. Perception accuracy scores tended to increase with years spent in school $(\mathrm{r}=0.40 ; \mathrm{P}=0.052)$.

\section{Discussion}

This study was designed around a tentative assumption that organic and conventional farmers placed a different degree of emphasis on the importance of soil in their management, and that this difference would be expressed in the accuracy of their perceptions of soil quality indicators. Results from this study could not confirm this. Differences in perception accuracy scores between organic and conventional farmers were observed in only two instances for individual indicators. Consequently, perceptions of soil quality indicators by conventional farmers were, for the most part, as accurate as perceptions by organic farmers. This finding is supported by McCallister (1996) who observed no difference in perception accuracy of soil properties between farming groups in a soil knowledge survey of Wisconsin farmers. In his survey, soil knowledge scores of 42 low-input farmers who did not use herbicides did not differ from conventional farmers who did.

As production approach was not associated with perception accuracy of soil quality indicators, other factors were anticipated to assist in the interpretation of results. This was not the case. Only one significant relationship for both soils was observed between perception accuracy scores and social and managerial characteristics evaluated in the study. Perception accuracy of soil quality indicators on "good" soils declined as more years were spent on a single farm. Such a finding seems paradoxical, as awareness of natural resources would be expected to increase on the same farm over time. However, it could be argued that knowledge about 
Table 4. Mean accuracy scores for perceptions of soil quality indicators on 'good' and 'problem' soils for conventional and organic farmers. Least significant differences (LSD) at $\mathbf{P} \leq .05$ are given for each comparison $(n=12)$.

\begin{tabular}{|c|c|c|c|c|c|c|}
\hline \multirow[b]{2}{*}{ Soil quality indicator } & \multicolumn{3}{|c|}{ - } & \multicolumn{3}{|c|}{ - 'Problem' soil- } \\
\hline & Conventional & Organic & LSD & Conventional & Organic & LSD \\
\hline Soil texture & $0.54^{l}$ & 0.63 & 0.24 & 0.67 & 0.88 & $0.20 *$ \\
\hline Soil color & 0.67 & 0.83 & 0.33 & 0.38 & 0.54 & 0.37 \\
\hline Topsoil depth & 0.67 & 0.88 & 0.27 & 0.67 & 0.58 & 0.26 \\
\hline Compaction & 0.71 & 0.54 & 0.25 & 0.46 & 0.46 & 0.34 \\
\hline Infiltration rate & 0.50 & 0.42 & 0.33 & 0.54 & 0.21 & 0.34 \\
\hline Water-holding capacity & 0.83 & 0.71 & 0.25 & 0.45 & 0.58 & 0.32 \\
\hline Soil structure & 0.88 & 0.71 & 0.21 & 0.50 & 0.67 & 0.29 \\
\hline PHYSICAL TOTAL & 4.80 & 4.72 & 0.78 & 3.67 & 3.92 & 0.78 \\
\hline Nitrogen & 0.33 & 0.17 & 0.30 & 0.54 & 0.46 & 0.34 \\
\hline Phosphorus & 0.21 & 0.58 & $0.29 * *$ & 0.25 & 0.33 & 0.31 \\
\hline Soil organic matter & 0.75 & 0.71 & 0.36 & 0.75 & 0.67 & 0.21 \\
\hline Soil pH & 0.54 & 0.67 & 0.31 & 0.46 & 0.75 & 0.31 \\
\hline Salinity & 0.71 & 0.83 & 0.28 & 0.58 & 0.83 & 0.26 \\
\hline CHEMICAL TOTAL & 2.54 & 2.96 & 0.80 & 2.58 & 3.04 & 0.60 \\
\hline Earthworms & 0.67 & 0.71 & 0.25 & 0.63 & 0.63 & 0.26 \\
\hline Soil smell & 0.67 & 0.63 & 0.30 & 0.54 & 0.58 & 0.29 \\
\hline BIOLOGICAL TOTAL & 1.34 & 1.34 & 0.44 & 1.17 & 1.21 & 0.40 \\
\hline TOTAL & 8.68 & 9.02 & 1.42 & 7.42 & 8.17 & 1.15 \\
\hline
\end{tabular}

${ }^{1}$ Scores for each indicator range from 0 to 1 . Higher scores imply more accurate perceptions.

*,**Significant at $\mathrm{P} \leq 0.05$ and 0.01 , respectively.

Table 5. One-way frequency analysis of correct, nearly-correct, and incorrect perceptions provided by study participants for soil quality indicators on 'good' and 'problem' soils $(n=24)$.

\begin{tabular}{|c|c|c|c|c|c|c|}
\hline Soil quality indicator & $\begin{array}{l}\text { Correct }^{1} \\
\text { perception }\end{array}$ & $\begin{array}{l}\text { Nearly-correct } \\
\text { perception }\end{array}$ & $\begin{array}{l}\text { Incorrect } \\
\text { perception }\end{array}$ & $\begin{array}{l}\text { Correct } \\
\text { perception }\end{array}$ & $\begin{array}{l}\text { - 'Problem' soil - } \\
\text { Nearly-correct } \\
\text { perception }\end{array}$ & $\begin{array}{l}\text { Incorrect } \\
\text { perception }\end{array}$ \\
\hline & & & & 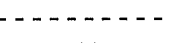 & $-\cdots$ & $\ldots \ldots$ \\
\hline Soil texture & 25 & 67 & 8 & 54 & 46 & 0 \\
\hline Soil color & 66 & 17 & 17 & 33 & 25 & 42 \\
\hline Topsoil depth & 63 & 29 & 8 & 34 & 58 & 8 \\
\hline Compaction & 34 & 58 & 8 & 25 & 42 & 33 \\
\hline Infiltration rate & 25 & 42 & 33 & 25 & 25 & 50 \\
\hline Water-holding capacity & 58 & 38 & 4 & 29 & 46 & 25 \\
\hline Soil structure & 58 & 42 & 0 & 33 & 50 & 17 \\
\hline Nitrogen & 12 & 25 & 63 & 29 & 42 & 29 \\
\hline Phosphorus & 21 & 37 & 42 & 13 & 33 & 54 \\
\hline Soil organic matter & 67 & 12 & 21 & 42 & 58 & 0 \\
\hline Soil pH & 37 & 46 & 17 & 42 & 37 & 21 \\
\hline Salinity & 63 & 29 & 8 & 50 & 42 & 8 \\
\hline Earthworms & 42 & 54 & 4 & 34 & 58 & 8 \\
\hline Soil smell & 42 & 46 & 12 & 29 & 54 & 17 \\
\hline
\end{tabular}

${ }^{1}$ Correct perception implies response category matched data class, nearly-correct perception implies response category off by one data class, and incorrect perception implies response category off by more than one data class. For soil texture, a nearly-correct perception implies that the perceived soil texture was adjacent to the data class soil texture on the textural triangle. An incorrect perception for soil texture implies perceived soil texture was not adjacent to the data class soil texture on the textural triangle. 
Table 6. Mean values for social and managerial characteristics among low, medium, and high perception score groups with Pearson correlation coefficients (r) for each characteristic. Analysis for 'good' soils.

\begin{tabular}{lcccc}
\multicolumn{1}{r}{ Variable } & Low & Medium & High & r \\
\hline Perception accuracy score & 7.0 & 9.1 & 10.4 & $\cdots$ \\
Farm size (ha) & 396 & 389 & 350 & -0.01 \\
Percent of land owned & 55 & 58 & 59 & 0.11 \\
Years at current farm & $29 \mathrm{a}^{l}$ & $23 \mathrm{ab}$ & $15 \mathrm{~b}$ & $-0.62^{* *}$ \\
Number of generations at current farm & 2.0 & 3.0 & 2.4 & 0.19 \\
Years of school completed & 13 & 14 & 15 & 0.40 \\
Walking frequency indices & & & & \\
$\quad$ Crop & 2.5 & 2.5 & 2.6 & 0.14 \\
$\quad$ Soil & 2.0 & 1.8 & 2.1 & 0.16 \\
Soil testing indices & & & & \\
$\quad$ Analytical & 1.8 & 1.9 & 1.8 & 0.12 \\
$\quad$ Descriptive & 5.0 & 5.3 & 4.5 & 0.19 \\
n & 8 & 8 & 8 & \\
\end{tabular}

${ }^{1}$ Grouped perception accuracy scores within a social or managerial characteristic followed by the same letter are not significantly different at $\mathrm{P} \leq 0.05$.

$*$, ** Correlation between perception accuracy scores and characteristic significant at $\mathrm{P} \leq 0.05$ and 0.01 , respectively.

natural resources possessed by newly-established farmers may be more recent, resulting in more accurate perceptions of soil characteristics. Another explanation for this finding is through a possible effect of education level. The correlation between perception accuracy and years spent in school was positive, and nearly significant. More years spent in school studying an agricultural-related discipline could contribute to greater knowledge of soil properties, and hence, more accurate perceptions of soil conditions on one's own farm.

Correlations between perception accuracy of soil quality indicators and other social and managerial factors were exceptionally weak, indicating that the factors chosen for analysis were inadequate to satisfactorily explain variation in perception accuracy for the number of participants involved in the study. Given these findings, it is likely that the accuracy or inaccuracy of farmers' perceptions of soil quality indicators is probably attributable more to the difficulty of observing the indicators in question rather than to social or managerial characteristics (except, for instance, participation in an organization that focuses on observing soil quality indicators).

Frequency analysis of correct, nearlycorrect, and incorrect perceptions indicated that farmers had a more difficult time accurately estimating the condition of their "problem" soils as compared to their "good" soils. Potential reasons for this vary. First, farmers may have more accurately estimated the condition of their " "good" soils by giving textbook answers (i.e., answers based on previous knowledge of what a "good" soil is supposed to be like). If this were the case, the likelihood of farmers giving the "right" answer to questions might be very high if the characteristics of their particular soil matched that of a prototypical "good" soil.

A more concrete reason for the difference in perception accuracy between "good" and "problem" soils has to do with farmers' trouble in estimating the problem within their "problem"' soil. Responses given for soil physical properties showed that farmers were uncertain which indicators were the limiting factors. Of the incorrect perceptions on "problem'" soils, farmers almost unanimously estimated their soils to be lighter in color, more compact with a slower infiltration rate, have lower available water-holding capacity and a more cloddy soil structure. In short, farmers perceived the physical condition of their "problem" soil to be much worse than it actually was. As with the "good", soil, this may reflect that farmers could have been estimating indicators with a prototypical "problem" soil in mind, suggesting that the implied meanings of the titles used to designate each soil may have biased farmers to give certain responses.

Despite the concern with semantics, it is important to point out that soil physical properties are generally not quantified during standard analytical soil tests, but rather become "known" to the farmer through in-field experiences such as passing over the field with implements, or watching crops during the growing season (McCallister and Nowak, 1998). The resolution associated with these general types of sensory assessments for the determination of soil physical characteristics is not known, but is probably not sufficient enough for accurate estimates at the level of resolution demanded through the response categories on the questionnaire. Improvement of perception accuracy of soil physical properties may be achieved through the use of "quick", in-field examinations, such as digging a hole. Though such an approach is simple, and might be viewed by some as unscientific, it would likely provide farmers with the necessary sensory information to make more accurate judgments of soil physical conditions.

Levels of nitrogen and phosphorus were difficult to estimate accurately by farmers on both soils. Low perception accuracy of nitrogen is understandable given its transient nature due to crop uptake and potential loss to the environment. Such an explanation is not entirely applicable for estimates of phosphorus, however, as it is less susceptible to loss by leaching. Phosphorus levels were underestimated by 15 of 24 farmers on "good" soils and 14 of 24 farmers on "problem" soils. Especially disturbing was that underestimates exceeded $67 \mathrm{~kg} \mathrm{P} \mathrm{ha}^{-1}$ about $30 \%$ of the time (data not shown). More frequent use of analytical soil tests or development of an in-field phosphorus test for use by farmers or crop consultants seems justified given the large discrepancy in estimated and observed levels.

In spite of the difficulties farmers had in estimating select indicators, farmers did an adequate job in estimating the surface condition of their "good" and "problem" soils. Farmers' perceptions were correct or nearly-correct over $75 \%$ of the time for the majority of indicators evaluated in the study, indicating the value of knowledge possessed by farmers about the soils they identified on their farms. 


\section{Conclusions}

For agricultural researchers, extension personnel, and crop consultants, findings from this study show the benefits associated with asking farmers about the characteristics of their soils as a first iteration to on-farm point-scale evaluation of soil quality. Inquiries about soils can take many forms, from extremely formal (as in this study) to relatively informal (talk about soils during idle conversation). Whatever the approach, the value of such inquiries cannot be overstated. Moreover, beginning on-farm evaluations of soil quality by talking with farmers first is not only resource-efficient, but shows farmers that their input is respected and valued.

Estimates provided by farmers about soil condition in their fields could be used any number of ways depending on the nature of the evaluation. For example, farmers' estimates of soil condition could help determine which soil quality indicators should be measured for an initial screening of a site. Furthermore, farmers' estimates may more effectively focus sampling efforts based on their knowledge of the spatial and temporal variability of a particular indicator. Finally, when soil quality evaluations are completed, results could be integrated with farmers' knowledge of management history in order to accurately define and diagnose problems and offer management scenarios for remedying those problems in order to promote a more sustainable agriculture.

Acknowledgments. We thank the participating farmers who spent valuable time completing our questionnaires. We also thank David Podoll and Fred Kirschenmann, two farmers from North Dakota, for their helpful comments and advice during the pretesting phase of this project.

\section{Literature Cited}

1. Acton, D.F., and L.J. Gregorich (eds.). 1995. The Health of our Soils-Toward Sustainable Agriculture in Canada. Centre for Land and Biological Resources Research. Research Branch, Agriculture and AgriFood Canada. Ottawa, Ont.

2. Bender, J. 1994. Future Harvest: Pesticide-free Farming. Univ. of $\mathrm{Ne}$ braska Press. Lincoln, NE.

3. Blair, J.M., P.J. Bohlen, and D.W. Freckman. 1996. Soil invertebrates as indicators of soil quality. In J.W. Doran and A.J. Jones (eds.). Methods for Assessing Soil Quality. Soil Sci. Soc. Am. Spec. Publ. 49. SSSA, Madison, WI. p. 273-291.

4. Blake, G.R., and K.H. Hartge. 1986. Bulk density. In A. Klute (ed.) Methods of Soil Analysis. Part 1. 2nd ed. Agron. Monogr. 9. ASA and SSSA, Madison, WI. p. 363-375.

5. Dahnke, W.C., and D.A. Whitney. 1988. Measurement of soil salinity. In Recommended Chemical Soil Test Procedures for the North Central Region. North Central Regional Publ. 221. North Dakota Agric. Exp. Stn. Bull. 499. p. 32-34.

6. Doran, J.W., and T.B. Parkin. 1996. Quantitative indicators of soil quality: A mimimum data set. In J.W. Doran and A.J. Jones (eds.). Methods for Assessing Soil Quality. Soil Sci. Soc. Am. Spec. Publ. 49. SSSA, Madison, WI. p. 25-67.

7. Eckert, D.J. 1988. Recommended pH and lime requirement tests. In Recommended Chemical Soil Test Procedures for the North Central Region. North Central Regional Publ. 221. North Dakota Agric. Exp. Stn. Bull. 499. p.6-8.

8. Garlynd, M.J., D.E. Romig, R.F. Harris, and A.V. Kurakow, 1994. Descriptive and analytical characterization of soil quality/health. In J.W. Doran, D.C. Coleman, D.F. Bezdicek, and B.A. Stewart (eds.). Defining Soil Quality for a Sustainable Environment. Soil Sci. Soc. Am. Spec. Publ. 35. ASA and SSSA, Madison, WI. p.159-168.

9. Garlynd, M.J., D.E. Romig, and R.F. Harris. 1995. Effect of a cropping systems shift from continuous corn on descriptive and analytical indicators of soil quality. In Agronomy abstracts. ASA, Madison, WI. p. 58.

10. Gee, G.W., and J.W. Bauder. 1986. Particle-size analysis. In A. Klute (ed.). Methods of Soil Analysis. Part 1. 2nd ed. Agron. Monogr. 9. ASA and SSSA, Madison, WI. p. 383-411.

11. Grossman, R.B., D.S. Harms, G.B. Muckel, and C.D. Franks. 1996. Evaluation of Soil Quality by Data and Techniques of the U.S. Soil Survey.
Proc. 9th ISCO Conf. 26-30 Aug. Bonn, Germany.

12. Gupta, S.C., and W.E. Larson. 1979. Estimating soil water retention characteristics from particle size distribution, organic matter percent, and bulk density. Water Resour. Res. 15:1633-1635.

13. Harris, R.F. and Bezdicek, D.F. 1994. Descriptive aspects of soil quality/ health. In J.W. Doran, D.C. Coleman, D.F. Bezdicek, and B.A. Stewart (eds.). Defining Soil Quality for a Sustainable Environment. Soil Sci. Soc. Am. Spec. Publ. 35. ASA and SSSA, Madison, WI. p. 23-35.

14. Hershfield, D.M. 1961. Rainfall Frequency Atlas of the United States. Weather Bureau Tech. Pap. no. 40. U.S. Gov. Print. Office, Washington, DC.

15. Howard, Sir A. 1947. The Soil and Health: A study of Organic Agriculture. Devin-Adair. New York.

16. Judd, C.M., E.R. Smith, and L.H. Kidder. 1991. Research Methods in Social Relations. Harcourt Brace Jovanovich, Inc. Fort Worth, TX.

17. Keeney, D.R., and D.W. Nelson. 1982. Nitrogen-inorganic forms. In A.L. Page (ed.). Methods of Soil Analysis. Part 2. Agron. Monogr. 9. ASA and SSSA, Madison, WI. p. 676-682.

18. Larson, W.E., and F.J. Pierce. 1991. Conservation and enhancement of soil quality. In Evaluation for Sustainable Land Management in the Developing World. Vol. 2. IBSRAM Proc. 12(2). Bangkok, Thailand. Int. Board for Soil Res. and Management.

19. Liebig, M.A. 1998. Evaluation of point-scale assessments of soil quality. Ph.D. diss. University of Nebraska-Lincoln.

20. Liebig, M.A., and J.W. Doran. 1998. Evaluation of point-scale assessments of soil quality. J. Soil Water Conserv. (in press).

21. Lockeretz, W., G. Shearer, and D.H. Kohl. 1981. Organic farming in the corn belt. Science. 211:540-547.

22. McCallister, R. 1996. How Wisconsin farmers understand and manage their soil landscape: A site-specific people and place methodological analysis. 
Ph.D. diss. Univ. of WisconsinMadison.

23. McCallister, R., and P. Nowak. 1998. Whole-soil knowledge and management: a foundation of soil quality. In R. Lal (ed.). Soil Quality and Soil Erosion. Soil Water Conserv. Soc. Ankeny, IA. (in press).

24. McKeague, J.A., C. Wang, and G.M. Coen. 1986. Describing and Interpreting the Macrostructure of Mineral Soils-A Preliminary Report. LRRI Contribution No. 84-50. Land Resource Research Institute. Research Branch, Agri. Canada. Ottawa, Ont.

25. Nelson, D.W., and L.E. Sommers. 1982. Total carbon, organic carbon, and organic matter. In A.L. Page (ed.). Methods of Soil Analysis. Part 2. 2nd ed. Agron. Monogr. 9. ASA and SSSA, Madison, WI. p. 539-579.

26. Olson, S.E., and L.E. Sommers. 1982. Phosphorus. In A.L. Page (ed.). Methods of Soil Analysis. Part 2. 2nd ed.
Agron. Monogr. 9. ASA and SSSA, Madison, WI. p. 403-430.

27. Romig, D.E., M.J. Garlynd, and R.F. Harris. 1996. Farmer-based assessment of soil quality: a soil health scorecard. In J.W. Doran and A.J. Jones (eds.). Methods for Assessing Soil Quality. Soil Sci. Soc. Am. Spec. Publ. 49. SSSA, Madison, WI. p. 39-60.

28. Romig, D.E., M.J. Garlynd, R.F. Harris, and K. McSweeney. 1995. How farmers assess soil health and quality. J. Soil and Water Conserv. 50:229236.

29. SAS Institute. 1990. SAS/STAT User's Guide. Version 6.0, 4th ed. Vol. 2. SAS Inst., Cary, NC.

30. Smith, J.L., and J.W. Doran. 1996. Measurement and use of $\mathrm{pH}$ and electrical conductivity for soil quality analysis. In J.W. Doran and A.J. Jones (eds.). Methods for Assessing Soil Quality. Soil Sci. Soc. Am. Spec.
Publ. 49. SSSA, Madison, WI. p. 169-185.

31. Soil Quality Institute. 1997. Willamette valley soil quality assessment card-draft. Oregon State Univ., Corvallis, OR.

32. Soil Survey Division Staff. 1993. Soil Survey Manual. USDA Handbook No. 18. U.S. Gov. Print. Office, Washington, D.C.

33. Soil Survey Staff. 1996. Keys to Soil Taxonomy. 7th ed. USDA-NRCS. Gov. Print. Office, Washington, D.C.

34. Stauber, K.N., C. Hassebrook, E. Bird, G.L. Bultena, E.O. Hoiberg, H. MacCormack, and D. MenanteauHorta. 1995. The promise of sustainable agriculture. In E. Bird, G.L. Bultena, and J.C. Gardner (eds.). Planting the Future. Iowa State Univ. Press, Ames, IA. p. 3-15.

\section{Consumers Union Finds "Unac- ceptable" Pesticide Levels for Children}

In a first-of-its-kind study of USDA data, Consumers Union analyzed the amount of pesticides on produce and found "unacceptable levels of some especially toxic pesticides" for children. "With some fruits and vegetables, kids who eat a single serving can exceed the safe daily limit of certain pesticides,", concluded the report, featured in Consumer Reports (March, 1999). The study also analyzed how toxic those pesticides are, and devised a "toxicity index" that integrates health risks and the actual amounts of pesticides on produce. Though the pesticide levels on all tested produce are within legal limits, many of those limits are at odds with what the government now deems safe for children, according to the report.

Of the 27 foods Consumers Union tested, seven had a toxicity index up to hundreds of times higher than the others: apples, grapes, green beans, peaches, pears, spinach, and winter squash. These products "are typically treated with more toxic pesticides and are often eaten unpeeled." The study also found that methyl parathion accounts for the "lion's share of the total toxicity of the foods we analyzed, and that domestic produce had more, or more toxic, pesticides than imported produce in twothirds of the cases.

Consumers Union "has asked the EPA to restrict or ban specific pesticide uses that expose children to residues above safe limits." It also recommends that the government provide financial and educational support for farmers making the transition to "less toxic ways of controlling pests." The government should also "direct more research toward finding safer ways of managing pests now controlled by the most toxic pesticides.",

The study, "Do You Know What You're Eating? An Analysis of U.S. Government Data on Pesticide Residues on Foods," is available on the Internet at http://www.consunion.org

\section{New Strategy will Clean Up Factory Farms}

A Unified National Strategy for Animal Feeding Operations, announced by the EPA and USDA, will reduce polluted runoff from 450,000 cattle, dairy, poultry, and hog farms where animals are raised in confined operations across the country. The strategy sets a goal of developing and implementing Comprehensive Nutrient Management Plans for all animal feeding operations by 2009 . Those plans will include actions to prevent or reduce runoff, improve storage and handling of manure, and identify new technologies to implement the plans. Voluntary programs will be the main approach for smaller operations, but larger operations with more than 1,000 animal units, which comprise 5 percent of all animal feeding operations, will be required to obtain Clean Water Act discharge permits.

The strategy is available on the Internet at http://www.epa.gov/owm; from the EPA at (202) 260-7786; or the USDA at (202) $720-5974$. 


\title{
Farmers' attitudes towards sustainable agriculture issues and environmental quality in a selected area of Bangladesh
}

\author{
M. Z. Rahman and H. Mikuni
}

Abstract. The sustainability issues associated with agricultural development are a growing concern worldwide. This study focussed on farmers' attitudes about environmental degradation and long term productivity loss that may result from implementation of modern agricultural technologies. The study was conducted in a selected area of Bangladesh and field level data were collected from the sampled farmers through personal interviewing. Findings revealed that more than two-thirds of the farmers confronted either a medium or high level of environmental problems due to intensive cultivation. Their main concerns were stress on soil fertility, loss of essential aquatic life, and reduction of earthworms and other beneficial organisms in soil. The farmers' recommended solutions were production of high yielding crop varieties with conservation management practices, and the balanced use of chemical fertilizers and organic manures. To apply these techniques, the top expectation of the farmers was to receive subsidies for agricultural inputs, and get easy-term credit from the government or non-government organizations. Interestingly, just half the farmers in the study area possessed a less than favorable attitude towards sustainability issues of agricultural development. In other words, to them these issues were of low or marginal priority. Only $6 \%$ of them expressed a highly favorable attitude (high priority) and $44 \%$ expressed a moderate attitude. Based on correlations, the individual farmer's age, education, family size, organizational participation, television exposure, communication behavior and environmental problem confrontation were identified as the main determinants of their attitudes about sustainability issues. Hence, these factors should be considered when formulating programs and policies for agriculture development that aim for long-term sustainability.

Key words: agricultural development, environmental degradation, productivity loss

\section{Introduction}

Agriculture most everywhere has had a profound influence on the earth's surface and the processes that operate thereon. Even where there has been no direct modification of landscapes, the indirect consequences, e.g., contamination with pesticide residues and water pollution, are often manifest (Mannion, 1995). Though agricultural technologies have increased production potential, the productivity of agricultural soils worldwide is in a general state of decline. Food grain production per capita has decreased significantly in some parts of the globe (Parr et al., 1992). Thus, there is a growing international focus on environmental soundness of practices, on regeneration of the productive capacity of soil resources, and on long term profitability of agriculture within an ecologically acceptable management system. Hence, in recent times the goal that has evolved for many farmers is an environmentally friendly alternative agriculture which is sustainable in the long run.
In Bangladesh, the most densely populated country in the world, agricultural productivity is at risk due to over-population along with natural calamities, poor management of soil and exploitive farming practices. Rapid degradation of soil and water resources are caused by overuse or misuse. Such increasing severity is also due to the intensive cultivation for the production of high yielding varieties (HYVs) to feed an expanding population. The high rate (about $80 \%$ ) of farmer illiteracy also exacerbates these disparities. Under such a vicious circle, farmers with their large families often care little about the potential impact of agricultural development on sustainability. They are most concerned with short-term production to relieve hunger. Thus, mismanaged soil is also becoming less productive and incapable of meeting the food needs of hungry people.

To boost short-term agricultural production, the extension approach in the country is mainly devoted to introducing high-input modern technologies and giving little attention to long-term environmental or resource consequences. Other than some limited interpersonal contact by extension organizations or other information media, environmental awareness is not well developed among Bangladesh farmers. Thus, a sensitivity or favorable

M.Z. Rahman is Assistant Professor in the Dept of Agric. Extension Education, Bangladesh Agricultural University, Mymensingh, Bangladesh. Presently he is a Ph. D. researcher in the Faculty of Applied Biological Science, Hiroshima University, Higashi Hiroshima, Japan. H. Mikuni is Professor and Dean, Faculty of Applied Biological Science, Hiroshima University, Higashi Hiroshima, Japan. 
Table 1. Trend of average farm size of farmer-owned land in Bangladesh [unit: ha; data for 2000 year is projected].

\begin{tabular}{llllll}
\hline & \multicolumn{5}{c}{ Average area per farm $^{\mathbf{1}}$} \\
\cline { 2 - 6 } \multicolumn{1}{c}{ Farm category } & $\mathbf{1 9 6 0}$ & $\mathbf{1 9 7 7}$ & $\mathbf{1 9 8 4}$ & $\mathbf{1 9 9 0}$ & $\mathbf{2 0 0 0}$ \\
\hline Small (0.02-1.0 ha) & 0.45 & 0.37 & 0.37 & 0.37 & 0.34 \\
Medium (1.0-3.0 ha) & 1.74 & 1.68 & 1.65 & 1.63 & 1.62 \\
Large (>3.0 ha) & 5.10 & 4.82 & 4.74 & 4.63 & 4.58 \\
All farm (country situation) & 1.43 & 1.09 & 0.90 & 0.82 & 0.73 \\
Rural situation & 1.12 & 0.76 & 0.66 & 0.59 & 0.52 \\
\hline
\end{tabular}

${ }^{1}$ Source: Andel et al. (1996).

attitude toward sustainability issues of agricultural development appears lacking. This is true even among the most innovative farming ventures which would likely be the first to recognize any potential longterm adverse impacts on resources and environment from implementing certain modern agricultural technologies aimed at increasing short-term food production. Instead, farmers often have little choice but to over-exploit the natural resource bases, like land and water, to fulfill their basic food, fiber and fuel needs. Under these circumstances, how farmers themselves perceive from a practical standpoint the importance of environment and sustainability as related to agricultural development needs to be investigated. The main objective of this study was to determine farmers' attitudes towards the environmental and sustainability issues of future agricultural development to improve production capability.

\section{Bangladesh Agriculture: Some Background Issues}

\section{Land use pattern and soil degradation}

The pressure of a rapidly expanding population has led to considerable land fragmentation over the past centuries and the average farm size is now between 0.8 and 2 ha. About $50 \%$ of the rural population owns no land at all, or only the land on which their homestead is located, and is classified as landless (Huq et al., 1990). Moreover, only $4 \%$ of the households own $40 \%$ of the total land, showing an unequal distribution of land among the different strata of farmers. Table 1 illustrates how land is decreasing per household for different farm catagories. Thus, the structure of land tenure and land holdings in Bangladesh will have an important bearing on farmers' perceptions and attitudes towards introducing sustainable farm technologies.

The predominance of rice (Oryza sativa) cultivation in Bangladesh has resulted in an overemphasis on the use of $\mathrm{N}$ (urea), where fertilizers are used, at the cost of other nutrients. Even when other elements are added they are usually limited to $P$ and K. Moreover, with most crops, not only the edible portion is harvested but also the straw for fuel and fodder. Sometimes the stubble is grazed or uprooted for fuel. The long-term result is that soils are low in organic matter and depleted of nutrients. Crop yields are, therefore, very low in relation to those of nations that manage their soils to sustain the resource. Consequently, Bangladesh soils are infertile, unproductive, and degraded, and in urgent need of organic matter to restore their quality and productivity (Islam, 1983). Farmers have failed to maintain the inputoutput balance of soil due to poverty issues and lack of motivation towards the future direction of sustainability.

Beginning with limited use in the early 1960s, chemical fertilizer consumption in Bangladesh has increased progressively over the last two decades. There is reason to believe that the increasing use of chemical fertilizer along with the decreasing application of organic manure is degrading soil quality. Continuous cultivation has also resulted in an acute deficiency of minor elements in Bangladesh soils (Shahabuddin et al., 1992). The intense application of pesticides has also possibly caused a decrease of beneficial soil organisms. Thus, soil health is deteriorating with continuous pressure of cultivation and cropping to feed the expanding population.

\section{Farming intensification and sustainability implications}

During 1973-1990, an increase in the cropped area accounted for only $16 \%$ of the increase in food grain production in Bangladesh (Hossain, 1991). The major factor in growth has been the crop-mix effect, i.e., reallocation of land from traditional to modern varieties of rice. The introduction of new technology also promoted a trend away from non-cereal to cereal production. Meanwhile, the area under pulses, oilseeds, and spices declined mainly due to the reallocation of land to wheat (Triticum aestivum) and boro (winter) rice. If this trend continues, it will likely result in diets that are less varied and balanced, malnutrition, and adverse welfare implications, particularly for the rural poor. This may lead to a situation where the agriculture sector is supporting more people but at a lower level of welfare (Shahabuddin et al., 1992).

It appears advantageous for food production that modern systems of sub-surface irrigation have substantially replaced the traditional ones. However, the unplanned extraction of greater amounts of groundwater has lowered the water table, causing environmental instability. Increasing groundwater use during the dry season has reduced both surface and groundwater availability, often causing tubewells to fail and, thus, creating shortages of even domestic water. For example, the groundwater table in Trishal Thana in the Mymensingh District has been steadily decreasing (S.M. Shirazi, 1995, unpublished data). This has caused major problems for human, animal, and fish life.

\section{Methodology}

\section{Locale of the study}

The study site was Shutiakhali village in Sadar Thana of Mymensingh District. The village is located in the agro-ecological zone region 9 (BARC, 1989) in the Brahmaputra flood plain. The study area consisted of 883 households. Almost half (342) of the total families were landless, and the rest were classified as marginal (302), small (170), medium (65), and large farm families (4). The total land area is $459 \mathrm{ha}$, of which 384 ha were arable. The soil is mostly a clay type with some loams 
and sandy loams. Almost half of the land is upland, about $40 \%$ is medium upland, and $10 \%$ is lowland. Half of the land is triple cropped; the rest is double and single cropped.

The national average of literacy is about $32 \%$ for individuals 7 years and older (BBS, 1995). The literacy rate in this area is about $21 \%$, well below the national average. There are 4 deep tubewells (owned by a group of farmers), 2 shallow tubewells (private) and 3 power pumps (government owned). In addition, there are 111 hand tubewells used for drinking water and irrigation. In this village there are only 3 power tillers owned privately. The main draft power for tillage is from cattle, which is the common scenario of Bangladesh. Crops grown in the village farms are mainly rice, vegetables, jute (Chorchorus capsularis), wheat, pulses, and oil seeds. The average economy of the farmers in this area is rated as poor.

\section{Sampling and data management}

The heads of the individual households were surveyed to collect the essential information for this study. These included farmers with land in cultivation, either their own or share-cropped. The 342 landless families were non-farmers and worked mostly as day-laborers or small traders in village markets. The remaining 541 farming households were considered as the population of the study from which 80 farmers were randomly selected for the survey. The study followed the "survey research design". Three types of questions/items, i.e., fixed alternative, openended, and scales, were used in preparing the interview questionnaire. All interviews were conducted on a personal basis. Data were collected during July, 1996. Pearson's Product Moment Correlation Coefficient " $r$ " (Garrett and Woodworth, 1981) was computed to determine the relationships among the variables. The selected individual characteristics of respondents were chosen as the independent variables and attitude was the only dependent variable.

\section{Definition and operationalization of some key variables}

Agricultural sustainability can be considered as a long-term goal that seeks to overcome problems and constraints that limit the economic viability, environmental soundness, and social acceptance of agricultural production systems (Parr et al., 1992). The 1990 U.S. Farm Bill defines sustainable agriculture as an integrated system of plant and animal production practices, having site-specific application, that over the long run will do the following:

- satisfy human food and fiber needs.

- enhance environmental quality and the natural resource base.

- make efficient use of non-renewable resources.

- use natural biological cycles and controls.

- improve the economic viability of farming systems.

- enhance the quality of life for farmers and society as a whole.

Along with the practical condition of agricultural development in Bangladesh, the aforesaid views were duly considered during formation of the attitude scale for farmers towards environment and sustainability issues of agricultural development.

Attitude is a mental position with regard to a fact or a state, or an individual's position on something in relation to a frame of reference. It is one's summative expression of knowledge, belief, and action toward any object, idea, person or concept. Of interest here was the farmer's attitude towards environmental problems and sustainability that may be associated with agricultural development. The Likert method of summated rating (Kothari, 1995) was used to compute the attitude score. There were 20 selected statements that the farmers were asked to respond as to "strongly agree," "agree," "undecided," "disagree," or "strongly disagree," with the corresponding rating score of $5,4,3,2$, or 1 . Thus, a respondent would get a score between 20 and 100 .

In this study, the environmental problems confronting farmers were those that had arisen in the development of the farming enterprise. The total rating score was considered in assessing this problem confrontation. The intensity of the problem for each statement was rated as "no," "low," "medium," or "high," with the respective score of $0,1,2$, or 3 . A total of 20 relevant statements were in the scale and, thus, a respondent would get a score between 0 and 60 .

\section{Profile of farmers' individual characteristics}

Individual feelings, thoughts, and predispositions are dependent on various aspects of the individual farmer's personal characteristics, capabilities and resources. However, for the sake of brevity, only a few of a farmer's personal characteristics were considered as a basis of attitude formation. Admittedly, such relationships are indeed complex and affected by many inter-linked factors. The profile of the farmers' selected individual characteristics are presented in Table 2.

\section{Results and Discussion}

\section{Environmental issues of farming development}

The development of a sustainable agriculture and environment are interdependent; that is, the health of agriculture depends on the proper functioning of environmental processes, and the health of the environment depends upon a respectful agriculture (Conway, 1990). Thus, an improperly managed agriculture can cause ecological degradation (Hossain et al., 1994). The environmental problem confrontation score of the farmers in the study area ranged from 6 to 51 with an average of 27. The statements which constituted the environmental problem score for the farmers are listed in Table 3. About threefourths of the families faced problems with medium to high levels of environmental consequences. The Table shows that "reduction of soil fertility with the cultivation of HYVs"; "fish, frogs, and other aquatic animals have been reduced in rivers or in open water bodies due to the use of pesticides"; and "use of chemical fertilizers decreased the earthworm population in the soil" had assigned problem intensity rankings of 1,2 , and 3 , respectively. Clearly, the over-all problem intensity is high in the study area, which is quite typical for Bangladesh.

The farmers expressed their opinions based on practical field experience and whether the technology/practices listed in 
Table 2. Salient features of the farmers' selected individual characteristics of the study area.

\begin{tabular}{|c|c|c|c|c|}
\hline \multirow{2}{*}{$\begin{array}{l}\text { The individual characteristics } \\
\text { (and operationalization) }\end{array}$} & \multicolumn{2}{|c|}{ Observed score } & \multirow{2}{*}{$\begin{array}{l}\text { Mean } \\
\text { Value }\end{array}$} & \multirow{2}{*}{$\begin{array}{l}\text { Standard } \\
\text { Deviation }\end{array}$} \\
\hline & Mini. & Maxi. & & \\
\hline 1. Age (exact years) & 25 & 73 & 45.44 & 9.31 \\
\hline 2. Schooling (years) & 0 & 14 & 4.84 & 3.79 \\
\hline 3. Rural background (rated score) & 5 & 72 & 17.39 & 9.56 \\
\hline 4. Family size (numbers) & 3 & 12 & 6.85 & 1.79 \\
\hline 5. Family members in farming (numbers) & 1 & 5 & 2.95 & 1.07 \\
\hline 6. Annual income (thousand US dollar) & 0.375 & 2.925 & 1.41 & 0.65 \\
\hline 7. Farm size (ha) & 0.21 & 3.5 & 1.14 & 0.65 \\
\hline 8. Organizational participation (rated score) & 0 & 45 & 3.12 & 7.93 \\
\hline 9. Training received (days) & 0 & 10 & 2.53 & 2.36 \\
\hline $\begin{array}{l}\text { 10. Newspaper exposure (number of issues } \\
\text { read month }{ }^{-1} \text { ) }\end{array}$ & 0 & 75 & 8.32 & 20.08 \\
\hline 11. Television exposure (hours month ${ }^{-1}$ ) & 0 & 90 & 25.85 & 28.12 \\
\hline 12. Communication behavior (rated score) & 7 & 30 & 17.12 & 10.70 \\
\hline $\begin{array}{l}\text { 13. Environmental problem confrontation } \\
\text { (rated score) }\end{array}$ & 6 & 51 & 27.25 & 10.70 \\
\hline
\end{tabular}

Table 3. Farmers' responses towards selected individual statements of environmental problems.

(Note: Out of a total of 20 statements, only the highest ranking 10 are listed here)

\begin{tabular}{lccc}
\multicolumn{1}{c}{ Types of problem issues } & $\begin{array}{c}\text { Total } \\
\text { score }\end{array}$ & $\begin{array}{c}\text { Rank } \\
\text { order }\end{array}$ & $\begin{array}{c}\text { No problem } \\
\text { (\% of farmers) }\end{array}$ \\
\hline $\begin{array}{l}\text { Soil fertility is reduced with HYV cultivation. } \\
\begin{array}{l}\text { Fish, frogs, and other aquatic animals have been } \\
\text { reduced in rivers or open water bodies due to the use } \\
\text { of pesticides. }\end{array}\end{array}$ & 84 & 1 & 15 \\
$\begin{array}{l}\text { Use of chemical fertilizers decreased the earthworm } \\
\text { population in the soil. }\end{array}$ & 79 & 3 & 21 \\
$\begin{array}{l}\text { Disease and insect infestation have increased due to the } \\
\text { introduction of HYVs of crops. }\end{array}$ & 74 & 4 & 20 \\
$\begin{array}{l}\text { Mishandling and untimely use of agro-chemicals are } \\
\text { polluting air and environment and causing an } \\
\text { increase in health hazards. }\end{array}$ & 72 & 5 & 15 \\
$\begin{array}{l}\text { Improper and excessive withdrawal of ground water for } \\
\text { irrigation is lowering the water table. }\end{array}$ & 71 & 6 & 23 \\
$\begin{array}{l}\text { Cultivation of green crops with the use of irrigation } \\
\text { water in the dry season is increasing the insect } \\
\text { populations in rural areas. }\end{array}$ & 70 & 7 & 20 \\
$\begin{array}{l}\text { Continuous cultivation of different crops makes the soil } \\
\text { less productive for sustainable future use. }\end{array}$ & 69 & 8 & 20 \\
$\begin{array}{l}\text { Expansion of land area for crop cultivation reduces the } \\
\text { forest area and, thus, rainfall is decreased. }\end{array}$ & 58 & 9 & 15 \\
$\begin{array}{l}\text { Beneficial soil microorganisms are under stress from the } \\
\text { use of toxic agrochemicals like pesticides, chemical } \\
\text { fertilizers, etc. }\end{array}$ & 57 & 10 & 24 \\
\hline
\end{tabular}

Table 4 might be a likely solution to minimize environmental problems, and if they were thought to be sustainable as well. The farmers believed that the cultivation of HYVs with modern management practices was the best way for minimizing problems, and that this approach was sustainable. Proper management practices include use of crop residues, cover crops, animal manures, and composts (Papendick, 1992). Thus, even though the adoption of HYVs with proper management practices was low the farmers agreed that this would be a solution to environmental problems. Proper and balanced use of chemical fertilizers along with sufficient organic manure, and proper use of the homestead area to produce household needs of fresh vegetables, flowers, or fruits, were considered to be important technologies/practices that should be adopted.

Farmers were asked to express their opinions as to what they should do to minimize environmental problems that would help to attain sustainability in agricultural development. "Farmers should discuss their problems among themselves and should help each other" was revealed as the number one opinion (Table 5). The others were: "farmers should have their own initiatives to minimize the problems, if any"; "they should use more HYVs of different crops for increased production"; and so on. Kashem (1996) reported similar responses in another Bangladesh study.

The farmers also expressed views about their expectations from the government, NGO's or other concerned authorities in order to minimize environmental problems associated with agricultural development. "Government should have a subsidy program for agriculture" and " "provide easy-term credit for the needy farmers to adopt modern technology" were the number 1 and 2 options, respectively. They opined that NGOs should work for self-income generation of the marginal and poor farmers, and the growers should be ensured of an adequate price for farm products. These statements clearly indicate their expectations for a better farming environment. Since farmers in Bangladesh are mostly in the marginal class many are in need of credit for newer technologies in order to continue operations.

\section{Farmers' attitudes towards sustainability issues}

The scores for farmers' attitudes towards sustainability issues ranged from 20 to 50 with an average of about 28 . Interestingly, $50 \%$ of the farmers did not regard sustainability issues as being very important and only $6 \%$ regarded them as being highly important. The overall intensity of attitude score was low in this study. It is 
Table 4. Technologies/practices that were either being used or considered for use by farmers to minimize environmental problems and were thought to be sustainable.

\begin{tabular}{|c|c|c|c|c|}
\hline \multirow{2}{*}{$\begin{array}{l}\text { Sustainable technologies/practices to minimize } \\
\text { environmental problems }\end{array}$} & \multicolumn{2}{|c|}{ Should be used } & \multicolumn{2}{|c|}{ Already Using } \\
\hline & Percent & Rank & Percent & Rank \\
\hline $\begin{array}{l}\text { 1. Cultivation of crop HYVs with modern management } \\
\text { practices. }\end{array}$ & 95 & 1 & 40 & 1.5 \\
\hline $\begin{array}{l}\text { 2. Proper and balanced use of chemical fertilizers } \\
\text { along with sufficient organic manure or other } \\
\text { biomass fertilizers. }\end{array}$ & 94.8 & 2.5 & 30 & 5.5 \\
\hline $\begin{array}{l}\text { 3. Cultivation of green manures to restore the soil } \\
\text { fertility. }\end{array}$ & 50 & 11.5 & 6.25 & 11 \\
\hline $\begin{array}{l}\text { 4. Use of Integrated Pest Management (IPM) systems } \\
\text { to control pests/diseases. }\end{array}$ & 52.5 & 10 & 8.75 & 10 \\
\hline $\begin{array}{l}\text { 5. Use of pesticides that do not have long term residual } \\
\text { effects. }\end{array}$ & 25 & 15 & 2.5 & 13 \\
\hline $\begin{array}{l}\text { 6. Crop rotation practices to maintain soil nutrient } \\
\text { balance. }\end{array}$ & 87.5 & 4.5 & 37.5 & 3.5 \\
\hline 7. Irrigation water with minimum minerals/salts. & 37.5 & 13.5 & 1.25 & 14 \\
\hline $\begin{array}{l}\text { 8. Careful handling and application of pesticides to } \\
\text { avoid dangers to health and environmental pollution. }\end{array}$ & 87.5 & 4.5 & 37.5 & 3.5 \\
\hline $\begin{array}{l}\text { 9. Transferring of resistance and good genetic } \\
\text { characteristics from local varieties into HYVs. }\end{array}$ & 86.25 & 6 & 0 & 0 \\
\hline $\begin{array}{l}\text { 10. Use of plant extracts and other organic materials to } \\
\text { control insects or diseases. }\end{array}$ & 50 & 11.5 & 5 & 12 \\
\hline $\begin{array}{l}\text { 11. Proper tillage and mulching operations to improve } \\
\text { soil fertility and erosion control. }\end{array}$ & 63.75 & 8 & 30 & 5.5 \\
\hline $\begin{array}{l}\text { 12. Adoption of technologies that are economical } \\
\text { and sustainable for future benefits. }\end{array}$ & 65 & 7 & 40 & 5 \\
\hline $\begin{array}{l}\text { 13. Proper utilization of homestead area to minimize } \\
\text { purchase of fresh vegetables, flowers, or fruits for } \\
\text { household use. }\end{array}$ & 94.8 & 2.5 & 22.5 & 8 \\
\hline $\begin{array}{l}\text { 14. Intercropping of suitable crops for proper utilization } \\
\text { of soil nutrients and management of intensive } \\
\text { cultivation. }\end{array}$ & 37.5 & 13.5 & 15 & 9 \\
\hline $\begin{array}{l}\text { 15. Utilization of indigenous technology to avoid } \\
\text { environmental hazards. }\end{array}$ & 56.3 & 9 & 28 & 7 \\
\hline
\end{tabular}

possible that many farmers were aware of environmental consequences that could result from implementing certain modern technologies but their attitude was influenced due to socioeconomic inability. In order to get a clearer picture of the attitude pattern, the details of the 10 highest ranked statements were analyzed and are presented in Table 6. "Day by day, the population of earthworms in soil is decreasing with the increased use of fertilizers and insecticides and thus, the desirable physiochemical properties of soil are deteriorating" was expressed as the number one issue in the attitude scale by the farmers. The second highest score was obtained for statement "the population of frogs is decreasing as the lethal effects of applied chemicals are detrimental for them. So, I think, the insect population in the environment is increasing.". formed their attitudes towards sustainability issues of agricultural development through their long experience with farming. Virtually, they had less chance to learn the modern issues of agriculture through formal education. In the study area, farmers with formal education were few in number as they were obliged to farm instead of attending school due to lack of finances.

Education. Nearly one-fourth (22.5\%) of the farmers were without any formal schooling, and $40 \%$ had schooling of 1 to 5 years. The relationship between the years of schooling and attitude toward sustainability issues of agricultural development was positively significant. This relationship reveals that formal education helped them form favorable attitudes towards these issues. Various studies have supported this view as well (Singh and Kunzroo, 1985; Kaur and Singh, 1991).

Family size. The relationship between family size and attitude of the farmers was found to be significantly negative and it indicates farmers with larger families had a more unfavorable attitude (i.e., less concern) towards sustainability issues of agricultural development. The background reason may be that farmers with larger families were more intensely occupied with providing sustenance for them through agricultural activities. Thus, with more family members, they had less time to consider the consequences of technology impacts in their farming business. They were more concerned with shortterm monetary benefits and more inclined to overlook future issues.

Organizational participation. Organizational participation of the farmers showed a positive significant relationship with their attitude of concern with sustainability issues of agricultural development. It is an indication that greater participation in different organizations helped them to form favorable attitudes on sustainability issues. Participation in several organizations helped them to obtain various pieces of information regarding agricultural development that consequently made them more sensitive to future environmental concerns (Kumar, 1991).

Media exposure. The correlation between TV exposure and attitudes of the farmers was positively significant and it indicates that watching TV programs 
Table 5. Farmers' perceived self responsibilities in order to minimize environmental problems and achieve sustainability in agricultural development.

\begin{tabular}{llc}
\hline Rank & F a r m e r s' op in ion & \% of farmers \\
\hline $\begin{array}{l}\text { 1. } \\
\text { Farmers should discuss their problems and should exchange their views } \\
\text { and experiences with each other. }\end{array}$ & 53.8
\end{tabular}

2. Farmers should have their own initiatives to minimize problems.

3. Farmers should use different crop HYVs for greater production.

4. More care should be taken in handling, storing and applying pesticides.

5. Optimum rates of chemical fertilizers should be applied along with organic manures or bio-fertilizers.

6. More trees should be planted for balance and natural diversity.

7. Farmers should follow the prescriptions and practices recommended by the concerned agricultural development agencies.

8. Green manuring practices should be adopted in farming systems.

9. Mulching with organic materials should be practiced.

10. Irrigation facilities in dry season through use of ground water should be improved. reduced as much as possible through formal schooling.

The significant negative correlation between family size and attitude towards sustainability issues of agricultural development further suggests that farmers should strive for smaller families. Thus, the present family planning campaign of the nation should be strengthened to reduce pressure on land. Findings also revealed that reduction in soil fertility and soil degradation were perceived as the top most problems caused by intensive cultivation of different crop HYVs and heavy dependence on the use of agro-chemicals.

Exchange of information among farmers through organizational participation. The farmers opined that they should solve their own problems related to achieving sustainable agriculture through consulting each other in group sharing of views and experiences. Farmers' organizational participation and attitudes were positively correlated. This reveals that farmers get better ideas and form a more favorable attitude towards problem solving if they are the part of a discussion group. Hence, it may be concluded that farmers organizations are vital for achieving a better understanding about the consequences of modern agriculture. Farmer cooperatives may be recommended as an approach in this process.

Effect of media exposure. Farmers' TV exposure and overall communication behaviors had a significant positive relationship towards their attitude formation. Media exposure, especially mass media, was found to be very low in the study area. Low income and illiteracy of the farmers contribute to a low quality of life and reduce awareness of the recent issues of farming development. Thus, the farmers, at least those with financial resources, should be motivated to be better exposed to mass media to acquire "awareness knowledge", (Rogers, 1995) from the grass-roots level workers of agricultural development.

Maintaining soil quality as a way to achieve sustainability. The farmers at least perceived that substandard or unbalanced use of agrochemicals and nutritional stress on the land were the main problem areas limiting the development of modern farming that would be sustainable in the long-term. Cultivation of HYVs with attitudes toward sustainability issues. 
Table 6. Status of the selected individual statements in the attitude scale.

(Note: Out of a total of 20 statements, only the highest ranking 10 orders are listed here)

\begin{tabular}{|c|c|c|}
\hline Statements used for the determination of farmers' attitude & $\begin{array}{l}\text { \% of total } \\
\text { score }\end{array}$ & Rank \\
\hline $\begin{array}{l}\text { 1. Day by day, the population of earthworms in soil is decreasing with } \\
\text { the increased use of fertilizers and insecticides. So, the physio- } \\
\text { chemical properties of soil are deteriorating. }\end{array}$ & 20 & 1 \\
\hline $\begin{array}{l}\text { 2. The population of frogs is decreasing in nature as the lethal effects of } \\
\text { applied fertilizers and pesticides are detrimental for them. So, I think } \\
\text { the insect population in the environment is increasing. }\end{array}$ & 19 & 2 \\
\hline $\begin{array}{l}\text { 3. Soil fertility is rapidly exhausted with the cultivation of HYV crops. } \\
\text { So, I am not so interested in their cultivation. }\end{array}$ & 18 & 3 \\
\hline $\begin{array}{l}\text { 4. HYV crops need high rates of fertilizer to get expected yields but } \\
\text { improved cultivation practices should also be applied. }\end{array}$ & 17 & 4.5 \\
\hline $\begin{array}{l}\text { 5. As I believe, it is better to adopt the IPM system of pest management } \\
\text { to minimize environmental pollution and cost of production. }\end{array}$ & 17 & 4.5 \\
\hline $\begin{array}{l}\text { 6. Rice and fish culture is a profitable modern practice to control small } \\
\text { weeds and insects, and to get more production from the same field. } \\
\text { So, I like to use this technique. }\end{array}$ & 16 & 6 \\
\hline $\begin{array}{l}\text { 7. I believe that homestead gardening is a good idea for land utilization } \\
\text { and for meeting food shortages and malnutrition in rural areas. With } \\
\text { this view, I practice this idea in my own homestead area. }\end{array}$ & 14 & 7.5 \\
\hline $\begin{array}{l}\text { 8. Farmers' discussions about 'agricultural development, environmental } \\
\text { protection, and the future of agriculture' are important issues. So, we } \\
\text { should motivate each other in this respect. }\end{array}$ & 14 & 7.5 \\
\hline $\begin{array}{l}\text { 9. I am using a balanced rate of chemical fertilizers and organic manure } \\
\text { to restore the fertility of soil and for sustainable production in the } \\
\text { future. }\end{array}$ & 12 & 9 \\
\hline $\begin{array}{l}\text { 10. I do not hesitate to use under ground water for irrigation since the } \\
\text { long term use of it does not cause salts and minerals to accumilate on } \\
\text { the upper crust of soil. }\end{array}$ & 11 & 10 \\
\hline
\end{tabular}

Table 7. Relationship between individual characteristics of the farmers and their attitude towards environment and sustainability issues of agricultural development.

\section{Individual characteristics of the farmers}

Correlation

1. Age

coefficient $(\mathbf{r})$

$\begin{array}{lc}\text { 1. Age } & 0.228^{*} \\ \text { 2. Years of schooling } & 0.224^{*} \\ \text { 3. Rural background } & 0.143 \\ \text { 4. Family size } & -0.235^{*} \\ \text { 5. Family members in farming } & 0.129 \\ \text { 6. Annual income } & 0.114 \\ \text { 7. Farm size } & 0.150 \\ \text { 8. Organizational participation } & 0.232^{*} \\ \text { 9. Training received } & 0.104 \\ \text { 10. Newspaper exposure } & 0.199 \\ \text { 11. Television exposure } & 0.228^{*} \\ \text { 12. Communication behavior } & 0.220^{*} \\ \text { 13. Environmental problem confrontation } & 0.581^{*}\end{array}$

* Significant at $5 \%$ level of probability [Critical value $(2$-tail, 0.5$)=+/-0.220$ ]

proper conservation management was suggested as the best sustainable approach for minimizing these problems. Other suggested technologies were the use of pesticides with short-term residual effects and essential for achieving sustainable agriculture. The NGOs were especially expected to work towards poverty alleviation by helping to create self-employment and income generating activities for the poor and marginal farmers of Bangladesh.

Acknowledgement. The authors duly acknowledge the financial support of The Japan Science Society in conducting this research project.

\section{References}

1. Andel, W. A. V. D., M. S. Hoque, M. A. Hossain and M. H. Rahman. 1996. In S. M. Farouk, and M. U. Salam (eds.). Sustainable Agriculture in Bangladesh: Addressing Issues Through Human Resource Development. J. Rural Development 26(1): 1-10.

2. BARC-Bangladesh Agric. Research Council. 1989. Quoted in S. Parveen. 1993. Attitude of the rural women towards homestead agricultural production. M. S. Thesis, Dept. of Agric. Extension Education, Bangladesh Agricultural University, Mymensingh, Bangladesh.

3. BBS-Bangladesh Bureau of Statistics. 1995. Statistical Pocket Book. Ministry of Planning, The People's Republic of Bangladesh.

4. Conway, G.R. 1990. Agroecosystems. In J. G. W. Jones and P. R. Street (eds.). Systems Theory Applied to Agriculture and the Food Chain. Elsevier Applied Science, London.

5. Garrett, H. E., and R. S. Woodworth. 1981. Statistics in Psychology and Education. Vakils, Feffer and Simsons Ltd, Bombay.

6. Hossain, M. 1991. The evolution of the food situation in Bangladesh. Paper presented at seminar on Political Economy and Agricultural Achievements in Low Income African and Asian Countries, March 20-22, France.

7. Hossain, S. M. A., M.U. Salam, and A. B. M. M. Alam. 1994. Scenario of farm environment of Bangladesh and methodology for quality assessment. In Proc. Workshop on Environment Issues, Graduate Training Institute, Bangladesh Agricultural University, Mymensingh, Bangladesh.

8. Huq, S., A. A. Rahman, and G.R. proper handling to avoid pollution, and a balanced use of chemical fertilizers along with applications of sufficient organic amendments. Easy-term credit and input subsidies provided by the government are 
Conway. 1990. Environmental aspects of agricultural development in Bangladesh. In S. Huq, A. A. Rahman, and G. R. Conway (eds.). Environmental Aspects of Agricultural Development in Bangladesh. UPL, Dhaka.

9. Islam, M. 1983. Soil management. Agricultural Research in Bangladesh, BARC, Dhaka.

10. Kashem, M. A. 1996. Implications of Environmental and Sustainability Issues for the Organization and Practice of Agricultural Extension: An Overview Summary of Bangladesh Study Area. Dept. of Agricultural Extension Education, Bangladesh Agricultural University, Mymensingh, Bangladesh.

11. Kaur, M. R. 1988. An evaluative study of women development program under Indo-German Dhauladhar
Project Palampur, District Kumgra, H. P., Thesis abstract, Hariana Agricultural University, India, Vol. XVI(4).

12. Kaur, R., and R. Singh. 1991. Adoption of smokeless chula by rural women. Indian J. Extension Education XXVII(1\&2): 34-38.

13. Kothari, C. R. 1995. Research Methodology - Methods and Techniques. Wishwa Prakashan, New Delhi.

14. Kumar, K. 1991. Cited in S. Parveen. 1993. Attitude of the rural women towards homestead agricultural production, M S Thesis, Dept. of Agricultural Extension Education, Bangladesh Agric. Univ., Mymensingh, Bangladesh.

15. Mannion, A. 1995. Agriculture and Environmental Change: Temporal and Spatial Dimensions. John Wiley \& Sons, New York.
16. Papendick, R. I. 1992. Soil quality the key to a sustainable agriculture. Amer. J. Alternative Agric. 7: 2-3.

17. Parr, J. F., R. I. Papendick, S. B. Hornick, and R. E. Meyer. 1992. Soil quality: Attributes and relationship to alternative and sustainable agriculture. Amer. J. Alternative Agric. 7: 5-11.

18. Rogers, E. M. 1995. Diffusion of Innovations (4th edn). The Free Press, New York.

19. Shahabuddin, Q., M.K. Mujeri, and S. Zohir. 1992. Land and Water Use in Rural Setting of Bangladesh. People, Development and Environment-A Complex Interlinkage in Bangladesh. BRDB \& IUCN, Dhaka.

20. Singh, B., and O. N. Kunzroo. 1985. Attitude of farmers towards goat and sheep farming. Indian J. Extension Education XXI(1\&2): 54-60.

\section{Groups Ask FDA to Ban Antibiot- ics for Farm Animals}

Five health, consumer, and other public interest groups recently asked the U.S. Food and Drug Administration to ban the use of certain antibiotics to fatten farm animals. Scientists have said that the use of antibiotics to promote animal growth increases the prevalence of bacteria that are resistant to antibiotics' effects, and jeopardizes human health. Adding antibiotics to livestock feed can lead to antibiotics resistance in foodborne pathogens, which can make cases of food poisoning difficult to treat or even deadly, according to the Center for Science in the Public Interest, one of the groups which signed the petition to the FDA. The other groups are the Environmental Defense Fund, Food Animal Concerns Trust, Public Citizen's Health Research Group, and Union of Concerned Scientists.

For more than 40 years, ranchers and growers have fed low levels of penicillin, tetracycline, and other antibiotics to poultry, cattle, and pigs to speed their growth and to cut costs, according to the Center. In the past two years, the World
Health Organization and the Centers for Disease Control and Prevention have called for ending the use of several antibiotics for growth promotion in livestock.

The groups' concerns are shared in Europe, where the Soil Association of England has released a report revealing "statistics on the enormous increases in use of the most common antibiotics such as penicillin, despite the supposed efforts of successful governments to curtail it. And it reveals some of the failures in the regulatory system which are leaving the human population exposed to the increasing risk of drug-resistant disease." In its magazine Living Earth (JanuaryMarch, 1999), the Association calls for a ban on all non-medical uses of antibiotics in agriculture.

\section{Organic Farmers Plan to Expand, According to Survey}

"Exploding consumer support for organic products" is encouraging 56 percent of organic farmers surveyed by the Organic Farming Research Foundation to increase their organic acreage and the number of crops they grow. According to the Foundation's "Third Biennial National Organic Farmers' Survey," which surveyed 1,200 certified organic farmers in 44 states, 63 percent of those surveyed plan to increase their number of markets and buyers. Nearly 87 percent of the respondents are single-family operations or family partnerships, and 62 percent farm full-time.

The farmers' top research priority was weed management, and their most useful resource for information was other farmers. Asked to name current constraints to organic production, the farmers responded, in order, uncooperative or uninformed extension agents, cost of organically allowable inputs, and distance or transport of organically allowable inputs. Current constraints to organic marketing included lack of consumer understanding about organic food, lack of organic marketing networks, and the distance between producer and market or delivery point.

"Third Biennial National Organic Farmers' Survey" is $\$ 10$ from OFRF, P.O. Box 440, Santa Cruz, CA 95061; (831) 426-6606. The Executive Summary of survey results is available on the Internet at http://www.ofrf.org 


\section{Rice and wheat production in Pakistan with Effective Microorganisms}

Tahir Hussain, T. Javaid, J.F. Parr, G. Jilani, and M.A. Haq

Abstract. There is a growing interest in the use of soil microbial inoculants as an alternative biological approach to a) improve soil quality, $b$ ) enhance the growth, yield and quality of crops, and c) reduce the inputs of chemical fertilizers and pesticides in agriculture worldwide. One such product that has received considerable attention, is Effective Microorganisms or EM; it consists of mixed cultures of beneficial microorganisms. A long-term field experiment was conducted at Faisalabad, Pakistan to determine the agronomic and economic merits of EM in a rice-wheat cropping system. Treatments were applied in a randomized complete block design that included: control (untreated); recommended chemical fertilizer (NPK); green manure (GM); farmyard manure (FYM); Effective Microorganisms (EM) alone; NPK +EM; GM + EM; and FYM + EM. Significantly higher grain and straw yields for both crops were obtained with NPK alone, with other treatments in the following order: NPK $>G M>F Y M>E M$. However, when fertilizer and organic amendments were combined with EM, higher grain and straw yields were obtained for each crop following the same order, i.e., $N P K+E M>G M+E M>$ $F Y M+E M$. The GM+EM treatment produced grain and straw yields for each crop that approached those for NPK alone. In all cases, the grain and straw yields from EM alone were higher than the controls. With few exceptions, EM applied in combination with NPK, GM and FYM caused a significant increase in nutrient uptake by the grain and straw of each crop. The uptake of NPK by both crops was higher for EM alone than for the controls. A comparative economic analysis of the treatments showed a significantly higher net return due to EM. The average net profit from rice and wheat production using EM was $\$ 44.90 \mathrm{ha}^{-1}$ and $\$ 62.35 \mathrm{ha}^{-1}$, respectively. The study indicates that EM can enhance maximum economic yields in a rice-wheat rotation and also improve soil productivity when applied with organic amendments.

\section{Introduction}

Agriculture in Pakistan is largely an irrigated enterprise in which farmers, particularly smallholders and subsistencetype farmers, face major constraints that can adversely affect production levels. The yields of rice (Oryza sativa) and wheat (Triticum aestivum) in Pakistan are generally low because of a steady decline in soil quality and productivity from uncontrolled

Tahir Hussain is Director, T. Javaid is Scientific Officer, G. Jilani is Deputy Director and M.A. Haq is Research Fellow, Nature Farming Research Center, University of Agriculture, Faisalabad, Pakistan; J.F. Parr is President, Nature Farming Research and Development Foundation, Lompoc, California. degradative processes such as salinization, depletion of plant nutrients, loss of soil organic matter, excessive irrigation and waterlogging, soil fertility decline, and wind and water erosion. The situation has been exacerbated by farmers who have intensified their tillage and cropping practices without making the necessary inputs (e.g., fertilizers, organic manures and composts) to restore and/or maintain soil fertility and productivity.

According to the 1980 census of Pakistan, some $75 \%$ of the total 4.1 million farms in the country are less than 5 hectares. These small farms comprise $35 \%$ of the total farm area and $40 \%$ of the total cultivated area (Government of Pakistan,
1983). Currently, both farm size and the economic status of the small farmers are continuing to decline. The advent of the Green Revolution in the 1960s appeared to hold some promise for small farmers in overcoming their problems of poor soil quality and low productivity. However, it soon became evident that most small farmers could not afford the costly inputs (i.e., chemical fertilizers, pesticides, mechanization, high-yielding varieties, and credit) necessary for them to participate in the Green Revolution.

The agricultural soils of Pakistan are generally calcareous, with high $\mathrm{pH}$ and low organic matter content (usually less than $1 \%$ ), and often have a high phosphorus-fixing capacity. Consequently, there are widespread deficiencies in available nitrogen and phosphorus. Some sandy soils are known to be deficient in potassium, while zinc and iron deficiencies have been identified in rice and fruit crops (Hussain and Muhammad, 1991; Hussain et al., 1995). While the judicious use of chemical fertilizers could correct these nutrient deficiencies and enhance the soil fertility status throughout the country, small and subsistence-level farmers consider such inputs to be too expensive. Consequently, the average N-P-K ratio of various chemical and organic fertilizers used by Pakistani farmers is about 1.0-0.3-0.02, and is considerably lower than the recommended ratio of 1.5-1.0-1.0 (Government of Pakistan, 1993).

Large farmers who practice conventional agriculture in Pakistan apply chemical fertilizers and pesticides in an effort to increase crop yields and improve crop quality. While such goals have often been achieved, the cost of these and other production inputs has made it difficult for 
many farmers to continue farming on a profitable basis. For example, according to recent estimates the average total production cost for wheat in Pakistan with optimum fertilization and management is $\$ 237.47 \mathrm{ha}^{-1}$ with an average net profit of $\$ 14.10 \mathrm{ha}^{-1}$. The total production cost for rice with optimum inputs is $\$ 299.76 \mathrm{ha}^{-1}$ with a net loss of $\$ 1.30 \mathrm{ha}^{-1}$ (Ahmad et al., 1993). In view of these increasingly narrow profit margins for two such important crops, the Government of Pakistan has asked its scientists to explore effective and affordable alternatives to chemical-based practices that would enhance the longterm sustainability of agriculture. Such alternatives are also needed to avoid the adverse effects of chemical fertilizers and pesticides on environmental quality, human and animal health, and food safety and quality.

One such alternative to conventional agricultural practices in Pakistan is the use of a microbial inoculant known as Effective Microorganisms (EM) within the context of nature farming and organic farming systems. The concept of EM was developed by Professor Teruo Higa, University of the Ryukyus, Okinawa, Japan. EM consists of mixed cultures of naturally-occurring, beneficial microorganisms applied as inoculants to increase the microbial diversity of soils and plants which, in turn, can improve soil quality and the growth, yield, and quality of crops (Higa and Wididana, 1991a; Higa and Parr, 1994). EM predominantly contains selected species of lactic acid bacteria, yeasts, actinomycetes, photosynthetic bacteria, and other types of organisms. All of these organisms are mutually compatible and can coexist in liquid cultures for extended periods (Higa, 1991).

EM is not a substitute for good management practices. It is, however, an added dimension for optimizing our best soil and crop management practices such as crop rotations, use of organic amendments, conservation tillage, recycling of crop residues and animal manures, and biocontrol of pests. When used properly, EM has been shown to enhance the beneficial effects of these practices on crop growth and yield (Arakawa, 1991; Higa and Kinjo, 1991; Higa and Wididana, 1991a,b; Hussain et al., 1993; Panchaban, 1991; Higa and Parr, 1994; Minami and Higa, 1994).
A number of beneficial effects of EM have been cited by these and other researchers including: a) increased decomposition of organic amendments and release of plant available nutrients; b) increased nutrient availability in the rhizosphere of plants; c) increased seed germination, emergence and seedling growth; d) increased biocontrol of plant diseases and pathogens through antagonism and antibiosis; e) increased plant growth from microbiallysythesized hormones (e.g., auxins) and growth factors; f) detoxification of residual phytotoxic substances; and g) increased production of antioxidants that suppress the adverse effects of free radicals in plant metabolism.

Extensive field trials in Pakistan on nature farming using EM technology began in 1989. Results have shown that EM has consistently increased crop yields while allowing some farmers to reduce their inputs of chemical fertilizers (Hussain et al., 1993). The present study was conducted to determine the effects of chemical fertilizer green manure, and farmyard manure applied singly or in combination with EM on crop growth, yield and net returns in a rice-wheat cropping system in Pakistan.

\section{Materials and Methods}

A three-year study was begun in 1990 to determine the agronomic and economic effects of EM in a rice-wheat rotation compared with the inputs that many farmers would normally make including chemical fertilizer (N-P-K), green manure (GM) and farmyard manure (FYM). The soil was a sandy clay loam ( $\mathrm{pH}, 7.8$; total $\mathrm{N}, 0.04 \%$; available $\mathrm{P}, 7.7 \mathrm{mg} / \mathrm{kg}$; available $\mathrm{K}, 85.4$ $\mathrm{mg} / \mathrm{kg}$; CEC, $9.2 \mathrm{cmol}^{(+)} / \mathrm{kg}$; organic matter, $0.55 \%$ ). The following treatments were applied to $4 \times 4 \mathrm{~m}$ plots using a randomized complete block design with three replications:

$$
\begin{aligned}
\mathrm{T} 1= & \begin{array}{l}
\text { Control (untreated, no amend- } \\
\text { ments) }
\end{array} \\
\mathrm{T} 2= & \text { Chemical fertilizers (N-P-K, 120- } \\
& \left.90-60 \mathrm{~kg} \mathrm{ha}^{-1}\right) \\
\mathrm{T} 3= & \text { Green manure (GM, } \left.10 \mathrm{t} \mathrm{ha}^{-1}\right) \\
\mathrm{T} 4= & \text { Farmyard manure (FYM, } \left.20 \mathrm{t} \mathrm{ha}^{-1}\right) \\
\mathrm{T} 5= & \text { Effective Microorganisms }(\mathrm{EM}, 10 \\
& \text { liters ha } \left.{ }^{-1}\right) \\
\mathrm{T} 6= & \mathrm{NPK}+\mathrm{EM}^{-}
\end{aligned}
$$

$\mathrm{T} 7=\mathrm{GM}+\mathrm{EM}$

$\mathrm{T} 8=\mathrm{FYM}+\mathrm{EM}$

The green manure crop (Sesbania aculeata) was grown each year in situ on the respective plots for 35 days and incorporated in the soil prior to transplanting rice (cv. KS-282) as a summer crop (May to September). After the rice was harvested, wheat (cv. PAK-81) was grown as a winter crop (October to April). An earlier paper by Hussain et al. (1995) reported that $S$. aculeata grown in this way will produce about $90 \mathrm{~kg} \mathrm{ha}^{-1}$ of total $\mathrm{N}$, most of which would become available during the year and would supply at least half of the $\mathrm{N}$ required by either crop. The green manure crop was applied at $10 \mathrm{t} \mathrm{ha}^{-1}$ (dry weight basis). Farmyard manure had an N-P-K ratio of 1-1-1 and was applied each year to respective plots at $20 \mathrm{t} \mathrm{ha}^{-1}$ (dry weight basis) which provided about $200 \mathrm{~kg} \mathrm{ha}^{-1}$ of total $\mathrm{N}$, with only 40 to 50 percent becoming available the first crop year. Chemical fertilizer was applied each year at the indicated N-P-K rates.

Effective microorganisms were applied in a formulation designated as EM 4. The stock solution of mixed cultures of beneficial microorganisms (mainly lactic acid bacteria, yeasts, actinomycetes and photosynthetic bacteria) was prepared by the International Nature Farming Research Center, Atami, Japan. EM stock solution was diluted $1: 1,000$ or 1:2,000 (EM:water) and spray-applied to the soil or crop of respective plots at each irrigation event, i.e., four and eight irrigations for wheat and rice, respectively. Consequently, EM 4 was applied to respective plots for both crops at a total rate of 10 liters $\mathrm{ha}^{-1}$ of stock solution. Both crops were irrigated with canal water; all other agronomic practices were applied equally for each treatment. Application rates for inputs in treatments 6-8 were the same as for treatments 2-5.

Crop growth and yield were recorded throughout the three-year study; soil, grain and straw samples were collected at each harvest for $\mathrm{N}, \mathrm{P}$, and $\mathrm{K}$ analysis. The data were analyzed statistically using the analysis of variance method of Steel and Torrie (1986); means were compared using Duncan's Multiple Range Test (Duncan, 1961). Crop yield (grain and straw) and nutrient uptake data are the means of three 
Table 1. Effect of Chemical Fertilizer, Organic Amendments, and Effective Microorganisms (EM) on Grain and Straw Yield of Paddy Rice.

\begin{tabular}{lcc}
\hline \multirow{2}{*}{ TREATMENTS } & \multicolumn{2}{c}{ CROP YIELD } \\
\cline { 2 - 3 } & RICE GRAIN & RICE STRAW \\
\hline Control (untreated) & $2.13 \mathrm{e}$ & $3.27 \mathrm{~d}$ \\
Chemical Fertilizer (NPK) & $4.77 \mathrm{a}$ & $7.28 \mathrm{a}$ \\
Green Manure (GM) & $3.80 \mathrm{c}$ & $5.17 \mathrm{bc}$ \\
Farmyard Manure (FYM) & $3.49 \mathrm{c}$ & $4.90 \mathrm{bc}$ \\
Effective Microorganisms (EM) & $2.52 \mathrm{~d}$ & $3.99 \mathrm{~cd}$ \\
NPK + EM & $4.96 \mathrm{a}$ & $7.77 \mathrm{a}$ \\
GM + EM & $4.19 \mathrm{~b}$ & $6.06 \mathrm{ab}$ \\
FYM + EM & $3.81 \mathrm{c}$ & $5.50 \mathrm{bc}$ \\
\hline
\end{tabular}

Control treatment did not receive NPK, organic amendments, or EM. Treatment means in a column sharing common letters are not significantly different at the $5 \%$ probability level. Values are the means of three years data.

Table 2. Effect of Chemical Fertilizer, Organic Amendments, and Effective Microorganisms (EM) on Grain and Straw Yield of Wheat.

\begin{tabular}{lcc}
\hline \multirow{2}{*}{ TREATMENTS } & \multicolumn{2}{c}{ CROP YIELD } \\
\cline { 2 - 3 } & WHEAT GRAIN & WHEAT STRAW \\
\hline Control (untreated) & $1.59 \mathrm{~d}$ & $2.99 \mathrm{~g}$ \\
Chemical Fertilizer (NPK) & $3.94 \mathrm{a}$ & $5.33 \mathrm{ab}$ \\
Green Manure (GM) & $2.73 \mathrm{c}$ & $4.25 \mathrm{de}$ \\
Farmyard Manure (FYM) & $2.41 \mathrm{c}$ & $3.83 \mathrm{ef}$ \\
Effective Microorganisms (EM) & $1.99 \mathrm{~d}$ & $3.34 \mathrm{fg}$ \\
NPK + EM & $4.18 \mathrm{a}$ & $5.73 \mathrm{a}$ \\
GM + EM & $3.22 \mathrm{~b}$ & $4.98 \mathrm{bc}$ \\
FYM + EM & $2.81 \mathrm{c}$ & $4.51 \mathrm{~cd}$ \\
\hline
\end{tabular}

Control treatment did not receive NPK, organic amendments, or EM. Treatment means in a column sharing common letters are not significantly different at the $5 \%$ probability level. Values are the means of three years data.

crop years (1990-92) with three replications per treatment per year.

\section{Results and Discussion Grain and straw yields}

The effects of chemical fertilizer (NPK), green manure (GM), farmyard manure (FYM), and Effective Microorganisms (EM) on the grain and straw yield of paddy rice and wheat are reported in $\mathrm{Ta}$ bles 1 and 2, respectively. In studies of crops followed the order of: NPK $>$ GM $>$ FYM $>$ EM > control (no EM). However, when the microbial inoculant (EM) was applied in combination with other treatments, the grain and straw yields of both crops increased, some significantly, over the individual treatments and in the same order: $\mathrm{NPK}+\mathrm{EM}>\mathrm{GM}+\mathrm{EM}>\mathrm{FYM}+\mathrm{EM}$. Grain and straw yields with EM alone, though lower than the other treatments applied singly, were all higher (in the case of rice grain, significantly higher) than the controls (no amendments applied).

The higher yields of grain and straw for both crops, when EM was applied in combination with the organic amendments, can be attributed largely to the activity of the introduced beneficial microorganisms which enhanced the decomposition of GM and FYM and the release of available nutrients for plant uptake. However, the fact that EM also increased grain and straw yields when applied with chemical fertilizer (i.e., NPK+EM) suggests that EM may have induced other mechanisms that exert positive effects on crop growth and yield (Higa and Wididana, 1991a,b; Parr et al., 1994). Nevertheless, it is noteworthy that the GM+EM treatment resulted in yields of both rice and wheat that approached those obtained with NPK alone. Others have reported similar results on the beneficial interaction of EM and organic amendments in soils and cropping systems (Higa and Kinjo, 1991; Karim et al., 1992; Ibrahim et al., 1993; Chowdhury et al., 1994; and Myint, 1994).

\section{Nutrient uptake}

The effect of chemical fertilizer (NPK), green manure (GM), farmyard manure (FYM), and Effective Microorganisms (EM) on nitrogen, phosphorus, and potassium uptake by grain and straw of paddy rice is reported in Tables 3, 4, and 5 , respectively. The wheat data for uptake of these three macronutrients is not reported here because of its similarity to the rice data both in treatment order and magnitude. In most cases, nutrient uptake by rice grain and straw was significantly higher than the control whether treatments were applied singly or in combination with EM. The uptake of NPK by rice grain and straw for treatments applied singly followed the order of: NPK > GM >
When the treatments were applied singly, the grain and straw yields of both 
Table 3. Effect of Chemical Fertilizer, Organic Amendments, and Effective Microorganisms (EM) on Nitrogen Uptake by Grain and Straw of Paddy Rice.

\begin{tabular}{lcc}
\hline \multirow{2}{*}{ TREATMENTS } & \multicolumn{2}{c}{ N UPTAKE } \\
\cline { 2 - 3 } & RICE GRAIN & RICE STRAW \\
\hline Control (untreated) & $20.8 \mathrm{~g}$ & $19.9 \mathrm{f}$ \\
Chemical Fertilizer (NPK) & $62.2 \mathrm{~b}$ & $43.0 \mathrm{~b}$ \\
Green Manure (GM) & $44.9 \mathrm{~d}$ & $28.3 \mathrm{de}$ \\
Farmyard Manure (FYM) & $39.9 \mathrm{e}$ & $24.4 \mathrm{e}$ \\
Effective Microorganisms (EM) & $26.8 \mathrm{f}$ & $17.6 \mathrm{f}$ \\
NPK + EM & $68.8 \mathrm{a}$ & $49.5 \mathrm{a}$ \\
GM + EM & $53.3 \mathrm{c}$ & $36.0 \mathrm{c}$ \\
FYM + EM & $44.7 \mathrm{~d}$ & $31.5 \mathrm{~d}$ \\
\hline
\end{tabular}

Control treatment did not receive NPK, organic amendments, or EM. Treatment means in a column sharing common letters are not significantly different at the $5 \%$ probability level. Values are the means of three years data.

Table 4. Effect of Chemical Fertilizer, Organic Amendments, and Effective Microorganisms (EM) on Phosphorus Uptake by Grain and Straw of Paddy Rice.

\begin{tabular}{lcc}
\hline \multirow{2}{*}{\multicolumn{1}{c}{ TREATMENTS }} & \multicolumn{2}{c}{ P UPTAKE } \\
\cline { 2 - 3 } & RICE GRAIN & RICE STRAW \\
\hline Control (untreated) & $3.0 \mathrm{f}$ & $1.0 \mathrm{~g}$ \\
Chemical Fertilizer (NPK) & $10.2 \mathrm{~b}$ & $3.4 \mathrm{~b}$ \\
Green Manure (GM) & $7.2 \mathrm{~d}$ & $2.1 \mathrm{~d}$ \\
Farmyard Manure (FYM) & $6.2 \mathrm{e}$ & $1.8 \mathrm{e}$ \\
Effective Microorganisms (EM) & $3.7 \mathrm{f}$ & $1.4 \mathrm{f}$ \\
NPK + EM & $11.6 \mathrm{a}$ & $3.9 \mathrm{a}$ \\
GM + EM & $8.4 \mathrm{c}$ & $2.7 \mathrm{c}$ \\
FYM + EM & $7.2 \mathrm{~d}$ & $2.2 \mathrm{~d}$ \\
\hline
\end{tabular}

Control treatment did not receive NPK, organic amendments, or EM. Treatment means in a column sharing common letters are not significantly different at the $5 \%$ probability level. Values are the means of three years data.

FYM > EM > control. However, when chemical fertilizer and the two organic amendments were applied in combination with EM, the uptake of NPK by grain and straw increased significantly in the order of $\mathrm{NPK}+\mathrm{EM}>\mathrm{GM}+\mathrm{EM}>\mathrm{FYM}+\mathrm{EM}$.

As with the yield data (Tables 1 and 2), a partial explanation for the increased nutrient uptake with EM applied with GM and FYM may be the result of a higher level of microbial activity which enhanced organic matter decomposition vented deficiencies at critical stages of seedling growth.

\section{Soil nutrient status}

The effects of chemical fertilizer, green manure, farmyard manure, and Effective Microorganisms on soil nutrient concentrations after three years of a rice-wheat rotation are reported in Table 6. All treatments showed significant increases in the soil NPK levels over the control. The highest residual soil nutrient levels resulted from the application of chemical fertilizer. Where treatments were applied singly, the nutrient concentrations followed the order of: NPK > GM > FYM > EM. However, in most cases, when EM was applied in combination with chemical fertilizer and the two organic amendments, soil nutrient concentrations increased significantly in the same order as the single treatments. Others have also reported that EM applied to soils in association with organic amendments (crop residues, green manures, animal manures, composts, etc.) promoted the release of plant available nutrients from these materials that resulted in higher soil nutrient concentrations (Higa and Wididana, 1991a; Lin, 1994; Lee, 1994; Sharifuddin et al., 1994).

The beneficial effects of EM are generally enhanced by the concurrent application of organic amendments because most of the microorganisms that comprise EM are heterotrophs and, thus, require organic substances as sources of carbon and energy for their growth and metabolism. Providing organic amendments ensures the optimum growth and activity of EM cultures and, concomitantly, the decomposition of organic amendments and release of plant nutrients (Higa and Parr, 1994).

\section{Economic considerations}

In view of the increased grain and straw yields in this study for both rice and wheat from the use of EM, the obvious question is whether its use in this cropping system is profitable. The costs, income, and net profit from using EM for rice and wheat production, with various treatments applied singly and in combination with EM, are reported in Tables 7 and 8, respectively. The greatest costs were associated with chemical fertilizer applied with and 
Table 5. Effect of Chemical Fertilizer, Organic Amendments, and Effective Microorganisms (EM) on Potassium Uptake by Grain and Straw of Paddy Rice.

\begin{tabular}{lcr}
\hline \multirow{2}{*}{ TREATMENTS } & \multicolumn{2}{c}{ K UPTAKE } \\
\cline { 2 - 3 } & RICE GRAIN & RICE STRAW \\
\hline Control (no EM) & $3.4 \mathrm{~g}$ & $42.3 \mathrm{~g}$ \\
Chemical Fertilizer (NPK) & $10.3 \mathrm{~b}$ & $114.3 \mathrm{~b}$ \\
Green Manure (GM) & $7.5 \mathrm{~d}$ & $75.9 \mathrm{e}$ \\
Farmyard Manure (FYM) & $6.5 \mathrm{e}$ & $70.6 \mathrm{e}$ \\
Effective Microorganisms (EM) & $4.4 \mathrm{f}$ & $53.6 \mathrm{f}$ \\
NPK + EM & $12.2 \mathrm{a}$ & $127.7 \mathrm{a}$ \\
GM + EM & $9.0 \mathrm{c}$ & $93.9 \mathrm{c}$ \\
FYM + EM & $7.7 \mathrm{~d}$ & $84.6 \mathrm{~d}$ \\
\hline
\end{tabular}

Control treatment did not receive NPK, organic amendments, or EM. Treatment means in a column sharing common letters are not significantly different at the $5 \%$ probability level. Values are the means of three years data.

Table 6. Effect of Chemical Fertilizer, Organic Amendments, and Effective Microorganisms (EM) on Soil Nutrient Concentrations After Three Years of a Rice-Wheat Rotation.

\begin{tabular}{|c|c|c|c|}
\hline \multirow[b]{2}{*}{ TREATMENTS } & \multicolumn{3}{|c|}{ SOIL NUTRIENT CONCENTRATIONS } \\
\hline & $\begin{array}{c}\mathrm{N} \\
(\%)\end{array}$ & $P$ & $\mathbf{K}$ \\
\hline Control (untreated) & $0.04 \mathrm{e}$ & $6.2 \mathrm{~g}$ & $80.2 \mathrm{f}$ \\
\hline NPK & $0.07 \mathrm{~b}$ & $7.8 \mathrm{~b}$ & $120.5 \mathrm{~b}$ \\
\hline GM & $0.06 \mathrm{c}$ & $7.3 \mathrm{e}$ & $100.2 \mathrm{~d}$ \\
\hline FYM & $0.06 \mathrm{c}$ & $7.3 \mathrm{e}$ & $103.2 \mathrm{~cd}$ \\
\hline EM & $0.05 \mathrm{~d}$ & $6.9 \mathrm{f}$ & 88.7 e \\
\hline $\mathrm{NPK}+\mathrm{EM}$ & $0.08 \mathrm{a}$ & $8.2 \mathrm{a}$ & $135.8 \mathrm{a}$ \\
\hline $\mathrm{GM}+\mathrm{EM}$ & $0.07 \mathrm{~b}$ & $7.5 \mathrm{~d}$ & $103.2 \mathrm{~cd}$ \\
\hline$F Y M+E M$ & $0.06 \mathrm{c}$ & $7.6 \mathrm{c}$ & $107.3 \mathrm{c}$ \\
\hline
\end{tabular}

Control treatment did not receive NPK, organic amendments, or EM. Treatment means in a column sharing common letters are not significantly different at the $5 \%$ probability level.

without EM. These treatments also produced the highest gross and net income. All of the amended treatments had a higher net income than the controls. The net income for treatments applied singly to both crops followed the order of : NPK $>$ GM > FYM $>$ EM. However, the net income was increased significantly when EM was applied in combination with chemical fertilizer and the two organic amendments, and followed the order of: NPK+EM > $\mathrm{GM}+\mathrm{EM}>\mathrm{FYM}+\mathrm{EM}$. Interestingly, the net income from GM+EM approached that obtained with NPK alone.
The net profit from application of EM was obtained as the difference in net income between treatments applied singly (no EM) and the corresponding treatments applied with EM. These differences are shown as net profit from EM for rice production in Table 7 and wheat production in Table 8. The highest net profit due to EM for both rice and wheat was obtained with the GM +EM treatment. Moreover, the net profit from EM alone was higher for both crops than from NPK + EM, mainly because of the high cost of chemical fertilizer.
These results should be of considerable interest to a) poor, subsistence-level farmers who cannot afford the cost of chemical fertilizers, and particularly in some developing countries where subsidies once available to facilitate their purchase no longer exist; and b) affluent, large-scale farmers who wish to reduce their dependence on chemical inputs to achieve a more sustainable agriculture and environment. The mean net profit from the use of EM in rice and wheat production over the three years of this study was $\$ 44.90$ and $\$ 62.35$ per hectare, respectively, as reported in Tables 7 and 8.

\section{Conclusions}

Effective Microorganisms or EM is a microbial inoculant consisting of mixed cultures of naturally-occurring beneficial microorganisms, which has been studied extensively in countries of the Asia-Pacific Region. Research has shown that EM can improve soil quality; increase the growth, yield, and quality of crops; and provide plant protection against diseases and pathogens. Results of a three-year study in Pakistan show that EM applied in combination with chemical fertilizer, green manure, and farmyard manure significantly increased the yields and nutrient uptake of rice and wheat, compared with these treatments applied singly. The net income over costs and net profit from EM were considerably higher due to the application of this microbial inoculant. These results indicate that EM applied together with good quality organic amendments is cost-effective, and may allow farmers to substantially reduce their inputs of chemical fertilizer while maintaining maximum economic yields and net profits.

\section{References}

1. Ahmad, B., Z. Hussain, and J. Longmire. 1993. Farm Management Handbook, Economic and Policy Analysis Project, ASSP/USAID. University of Agriculture, Faisalabad, Pakistan.

2. Arakawa, Y. 1991. Kyusei Nature Farming in Japan. In J.F. Parr, S.B. Hornick, and C.E. Whitman (eds.). Proceedings of the First International Conference on Kyusei Nature Farming. U.S. Department of Agriculture, Washington, DC. p. 20-23. 
Table 7. Cost, Income, and Net Profit from Effective Microorganisms (EM) for Rice Production with Various Treatments Applied Singly and in Combination with EM.

\begin{tabular}{lcccc}
\hline \multirow{2}{*}{ TREATMENTS } & & \multicolumn{2}{c}{ INCOME } & PROFIT \\
\cline { 3 - 5 } & COSTS & GROSS & NET & NET (EM) \\
\hline Control (untreated) & - & 376.90 & 376.90 \\
NPK & 111.00 & 843.80 & 732.80 & \\
GM & 33.40 & 668.00 & 634.60 & \\
FYM & 33.40 & 614.50 & 581.10 & 56.40 \\
EM & 13.40 & 446.70 & 433.30 & 21.60 \\
NPK + EM & 124.40 & 878.80 & 754.40 & 57.60 \\
GM + EM & 46.80 & 739.00 & 692.20 & 44.00 \\
FYM + EM & 46.80 & 671.90 & 625.10 & $\$ 44.90$ \\
\cline { 3 - 5 } & & & MEAN & \\
\hline
\end{tabular}

Values are the means of three years data.

Chemical fertilizer applied at:

$$
\begin{aligned}
120 \mathrm{~kg} \mathrm{~N} \mathrm{ha}^{-1} \text { (unit cost, } \$ 0.34 \mathrm{~kg}^{-1} \text { ) } & =\$ 40.80 \\
90 \mathrm{~kg} \mathrm{P} \mathrm{ha}^{-1} \text { (unit cost, } \$ 0.56 \mathrm{~kg}^{-1} \text { ) } & =\$ 50.40 \\
60 \mathrm{~kg} \mathrm{~K} \mathrm{ha}^{-1} \text { (unit cost, } \$ 0.33 \mathrm{~kg}^{-1} \text { ) } & =\$ \frac{\$ 19.80}{\text { TOTAL }}=\$ 111.00
\end{aligned}
$$

Green manure applied at $10 \mathrm{t} \mathrm{ha}^{-1}$.

$$
\text { Cost of seed, rotovating, sowing }-\$ 33.40 \mathrm{ha}^{-1} \text {. }
$$

Farmyard manure applied at $20 \mathrm{t} \mathrm{ha}^{-1}$ (unit cost, $\$ 1.67 \mathrm{t}^{-1}$ ).

Effective Microorganisms applied to rice (1:2,000 dilution) at each of 8 irrigations; total application rate of 10 liters $\mathrm{ha}^{-1}$ of EM stock solution (unit cost, $\$ 1.67$ per application).

Market price of grain and straw:

$$
\begin{aligned}
& \text { Rice grain }-\$ 167.70 \mathrm{t}^{-1} \\
& \text { Rice straw }-\$ 6.70 \mathrm{t}^{-1}
\end{aligned}
$$

3. Chowdhury, A.R., M.M. Hossain, M.S. Mia, A.J.M.S. Karim, J. Haider, N.I. Bhuiyan and $\mathrm{Kh}$. Saifuddin. 1994. Effect of organic amendments and EM on crop production in Bangladesh. In J.F. Parr, S.B. Hornick, and M.E. Simpson (eds.). Proceedings of the Second International Conference on Kyusei Nature Farming. U.S. Department of Agriculture, Washington, DC. p. 155-163.

4. Duncan, D.B. 1961. Multiple Range and Multiple F-Tests. Biometrics 11: $1-42$.
5. Government of Pakistan. 1983. Pakistan Census of Agriculture (1980). Vol. II, Part 2: Province Report-Punjab. Agriculture Census Organization, Statistics Division, Islamabad, $\mathrm{Pa}$ kistan.

6. Government of Pakistan. 1993. Pakistan Fertilizer Related Statistics. Planning and Developments Division, National Fertilizer Development Center, Islamabad, Pakistan.

7. Higa, T. 1991. Effective Microorganisms: A biotechnology for mankind. In J.F. Parr, S.B. Hornick, and C.E.
Whitman (eds.). Proceedings of the First International Conference on Kyusei Nature Farming. U.S. Department of Agriculture, Washington, DC. p. 8-14.

8. Higa, T. and G. N. Wididana. 1991a. Concept and theories of Effective Microorganisms. In J.F. Parr, S.B. Hornick, and C.E. Whitman (eds.). Proceedings of the First International Conference on Kyusei Nature Farming. U.S. Department of Agriculture, Washington, DC. p. 118-124.

9. Higa, T. and G.N. Wididana. 1991b. Changes in the soil microflora induced by Effective Microorganisms. In J.F. Parr, S.B. Hornick, and C.E. Whitman (eds.). Proceedings of the First International Conference on Kyusei Nature Farming. U.S. Department of Agriculture, Washington, DC. p.153-162.

10. Higa, T. and S. Kinjo. 1991. Effect of lactic acid fermentation bacteria on plant growth and soil humus formation. In J.F. Parr, S.B. Hornick, and C.E. Whitman (eds.). Proceedings of the First International Conference on Kyusei Nature Farming. U.S. Department of Agriculture, Washington, DC. p. 140-147.

11. Higa, T. and J.F. Parr. 1994. Beneficial and Effective Microorganisms for a Sustainable Agriculture and Environment. International Nature Farming Research Center, Atami, Japan. $16 \mathrm{p}$.

12. Hussain, T. and S. Muhammad. 1991. Nature Farming in Pakistan. In J.F. Parr, S.B. Hornick, and C.E. Whitman (eds.). Proceedings of the First International Conference on Kyusei Nature Farming. U.S. Department of Agriculture, Washington, DC. p. 87-100.

13. Hussain, T., A.K. Khan, G. Jilani, M.A. Abbas and M. Yaseen. 1993. Prospects of using EM technology for wheat production. J. Agric. Research 31: 37-41.

14. Hussain, T., G. Jilani, M. Yaseen and M.A. Abbas. 1994. Effect of organic amendments and EM on crop production in Pakistan. In J.F. Parr, S.B. Hornick, and M.E. Simpson (eds.). Proceedings of the Second International Conference on Kyusei Nature Farming. U.S. Department of Agriculture, Washington, DC. p. 132-139. 
Table 8. Cost, Income, and Net Profit from Effective Microorganisms (EM) for Wheat Production with Various Treatments Applied Singly and in Combination with EM.

\begin{tabular}{lrrrr}
\hline \multirow{2}{*}{ TREATMENTS } & & \multicolumn{2}{c}{ INCOME } & PROFIT \\
\cline { 3 - 4 } & COSTS & GROSS & NET & NET (EM) \\
\hline Control (untreated) & - & 311.60 & 311.60 & \\
NPK & 111.00 & 703.00 & 592.00 & \\
GM & 33.40 & 505.60 & 472.20 & \\
FYM & 33.40 & 448.90 & 415.50 & \\
EM & 6.70 & 376.60 & 369.90 & 58.30 \\
NPK + EM & 117.70 & 748.40 & 630.70 & 38.70 \\
GM + EM & 40.10 & 595.30 & 555.20 & 83.00 \\
FYM + EM & 40.10 & 525.00 & 484.90 & 69.40 \\
\cline { 3 - 4 } & & & MEAN & $\$ 62.35$ \\
\hline
\end{tabular}

Values are the means of three years data.

Chemical fertilizer applied at:

$$
\begin{aligned}
120 \mathrm{~kg} \mathrm{~N} \mathrm{ha}^{-1} \text { (unit cost, } \$ 0.34 \mathrm{~kg}^{-1} \text { ) } & =\$ 40.80 \\
90 \mathrm{~kg} \mathrm{P} \mathrm{ha}^{-1} \text { (unit cost, } \$ 0.56 \mathrm{~kg}^{-1} \text { ) } & =\$ 50.40 \\
60 \mathrm{~kg} \mathrm{~N} \mathrm{ha}^{-1} \text { (unit cost, } \$ 0.33 \mathrm{~kg}^{-1} \text { ) } & =\$ 19.80 \\
\text { TOTAL } & =\$ 111.00
\end{aligned}
$$

Green manure applied at $10 \mathrm{t} \mathrm{ha}^{-1}$.

$$
\text { Cost of seed, rotovating, sowing }-\$ 33.40 \mathrm{ha}^{-1} \text {. }
$$

Farmyard manure applied at $20 \mathrm{t} \mathrm{ha}^{-1}$ (unit cost, $\$ 1.67 \mathrm{t}^{-1}$ ).

Effective Microorganisms applied to wheat (1:1,000 dilution) at each of 4 irrigations; total application rate of 10 liters $\mathrm{ha}^{-1}$ of EM stock solution (unit cost, $\$ 1.67$ per application).

Market price of grain and straw:

$$
\begin{aligned}
& \text { Wheat grain }-\$ 133.40 \mathrm{t}^{-1} \\
& \text { Wheat straw }-\$ 33.30 \mathrm{t}^{-1}
\end{aligned}
$$

15. Hussain, T., G. Jilani, J.F. Parr and R. Ahmad. 1995. Transition from conventional to alternative agriculture: The role of green manure in substituting for inorganic $\mathrm{N}$ fertilizers in a ricewheat farming system. Amer. J. Alternative Agric. 10(3):133-137.

16. Ibrahim, M., M.A. Avais, N. Ahmad and A. Khair. 1993. Effect of Effective Microorganisms on wheat yield. In Proceedings of the First National Seminar on Nature Farming. University of Agriculture, Faisalabad, Pakistan. p. 50-53.
17. Karim, A.J.M.S., A.R. Chowdhury, and J. Haider. 1992. Effect of manuring and Effective Microorganisms on physicochemical properties of soil and yield of wheat. In Proceedings of the First APNAN Conference on EM Technology. Asia-Pacific Natural Agriculture Network, Bangkok, Thailand.

18. Lee, K.H. 1994. Effect of organic amendments and EM on the growth and yield of crops and on soil properties. In J.F. Parr, S.B. Hornick, and M.E. Simpson (eds.). Proceedings of the Second International Conference on Kyusei Nature Farming. U.S. Department of Agriculture, Washington, DC. p. 142-147.

19. Lin, D.L. 1994. Nature Farming in Taiwan: Effect of organic amendments and EM on rice production. In J.F. Parr, S.B. Hornick, and M.E. Simpson (eds.). Proceedings of the Second International Conference on Kyusei Nature Farming. U.S. Department of Agriculture, Washington, DC. p. 148-152.

20. Minami, T. and T. Higa. 1994. Kyusei Nature Farming in Japan: Effect of EM on the yield of paddy rice. In J.F. Parr, S.B. Hornick, and M.E. Simpson (eds.). Proceedings of the Second International Conference on Kyusei Nature Farming. U.S. Department of Agriculture, Washington, DC. p. 97102.

21. Myint, C.C. 1994. Effect of organic amendments and EM on rice production in Myanmar. In J.F. Parr, S.B. Hornick, and M.E. Simpson (eds.). Proceedings of the Second International Conference on Kyusei Nature Farming. U.S. Department of Agriculture, Washington, DC. p. 82-91.

22. Panchaban, S. 1991. Effect of EM on growth and yield of corn. In J.F. Parr, S.B. Hornick, and C.E. Whitman (eds.). Proceedings of the First International Conference on Kyusei Nature Farming. U.S. Department of Agriculture, Washington, DC. p. 132-139.

23. Parr, J.F., S.B. Hornick, and D.D. Kaufman. 1994. Use of microbial inoculants and organic fertilizers in agricultural production. Extension Bulletin No. 394. Food and Fertilizer Technology Center (FFTC), Taipei, Taiwan. 16p.

24. Sharifuddin, H.A.H., M.F. Shahbuddin, and A.R. Zaharah. 1994. Effect of organic amendments and EM on production of food crops in Malaysia. In J.F. Parr, S.B. Hornick, and M.E. Simpson (eds.). Proceedings of the Second International Conference on Kyusei Nature Farming. U.S. Department of Agriculture, Washington, DC. p. 171-178.

25. Steel, R.G.D. and J.H. Torrie. 1986. Principles and Procedures of Statistics, Second Edition. McGraw-Hill, Inc., New York. 187 p. 


\title{
Farm Profile: Sörtorp, an organic farm in Sweden
}

\author{
William Lockeretz
}

About $120 \mathrm{~km}$ west of Stockholm, beside a beautiful lake in a landscape of farmland interspersed with evergreen forests, lies perhaps the best known and most frequently visited organic farm in Sweden. As managed by Kalle and Inger Källander since 1982, Sörtorp has become an impressive example of how, with careful planning and management, a farm's available resources can be fashioned into a stable, productive system whose diverse components work together as an organic whole. This cardinal principle of organic farming is often voiced in the abstract, but to achieve it in practice is another matter. It requires a sustained willingness and ability to learn, to devise ingenious uses for the farm's land and facilities, and to try different approaches to solve existing problems and adapt to changing conditions. All this is abundantly evident at Sörtorp.

\section{The People}

Kalle and Inger Källander were still university students when they decided in the early 1970s to become farmers, despite knowing little about agriculture. Kalle, who believed strongly in protecting nature and the environment, was eager to put his studies to use in a practical way. Inger wanted to be able to keep animals and to live in nature, not just visit it. Later she, too, became very interested in environmental protection.

For a year they farmed on a very small scale with two friends while finishing their courses at the University of Uppsala (his in biology and mathematics, hers in English, French, and Spanish). In 1973 they began commercial-scale farming, renting a farm

William Lockeretz is Professor, School of Nutrition Science and Policy, Tufts University, Medford, MA 02155; wlockeretz@infonet.tufts.edu.

Volume 14, Number 1, 1999 near their current one that they would manage for nine years.

Largely inexperienced, they gained the necessary knowledge by a combination of reading, trial and error, and asking other farmers. "How do we harrow?" was the level of question that they found themselves plaintively asking their neighbors. But not having been trained or brought up in farming was not all bad: they credit it with leading them to try things that other people would not even have considered.

They have always farmed organically, although at first they didn't know that. Organic farming was not a recognized concept in Sweden in the early 1970s. (A related approach, Biodynamic Agriculture, had a long history in Sweden, but they were not attracted to the philosophy behind it.) For them, farming any other way simply was inconceivable; they could not accept using poisons to raise food. Shortly afterward, they made contact with others in Sweden who were farming the same way. Since there were no books on organic farming in Swedish at the time, Inger put her language training to use in translating materials from other countries. Years later, she contributed to filling that gap with four books of her own.

For both, organic farming has become much more than a way to manage their particular farm. In 1985, Inger cofounded the Ecological Farmers of Sweden, of which she has been president since 1994. (In Sweden, as in the other Nordic countries, "ecological agriculture" is identical to what in the U.S. is called "organic agriculture.") Its membership consists of 1,600 out of the approximately 2,800 certified organic farmers in Sweden. It is the only group working nationally on behalf of organic farmers, through political activity, consultations on government development programs, publications, educational programs, local organization of farmers, and coordination of the ecological agriculture movement (Ekologiska Lantbrukarna i Sverige, 1996). Inger also was recently elected to the Royal Academy of Forestry and Agriculture, where she is the only member concerned with organic farming.

Kalle, for his part, has been vice president of KRAV, the country's main organic certification organization, since helping to found it at Sörtorp in 1985. KRAV was established under the Ecological Farmers, although it was made a separate entity to keep certification independent of an organization that represents its farmermembers' interests. Kalle also is a Green Party member in the Katrineholm district council, where he has been trying to get local schools to offer higher quality food, especially food produced organically.

\section{The Farm and Its Setting}

Before it was acquired by Kalle and Inger in 1982, Sörtorp "'Southern Smallholding") had been under intensive conventional management for many years, raising only hogs and continuous oats, and seriously infested with weeds. Now it produces a highly diversified array of vegetables, grains, forages, and meat animals, all organically certified (Table 1). It receives a continuous stream of visitors from Sweden and elsewhere, including organic farmers, farmers thinking about converting, consumer and environmental groups, and students. Kalle and Inger do not offer Sörtorp as a model for other farmers to follow exactly. Rather, they consider it an example of how the general principles of organic farming can be applied under the circumstances of a particular farm.

The natural resources they work with are modest. Including rented land, they 
Table 1. Sörtorp at a glance.

Location: $\quad$ East central Sweden, $120 \mathrm{~km}$ west of Stockholm $\left(59^{\circ} 06^{\prime} \mathrm{N}, 16^{\circ} 18^{\prime} \mathrm{E}\right)$ Nearest city: Katrineholm (about $15 \mathrm{~km}$ away, population about 30,000 )

History:

Bought by Kalle and Inger Källander in 1982

Previously in specialized, conventional management

All production certified organic since 1985

Land (ha):

Cropland: 25 owned, 11 rented

Permanent pasture: 8 owned, 5 rented

Forest: 20 owned

Crops:

Field crops: 21 ha (small grains, grass-clover, peas)

Vegetables: 3 ha (cabbage, onions, carrots, leeks, parsnips, potatoes, etc.)

Others: strawberries, chokeberries, rhubarb, apples

Livestock:

Beef cattle: 9 cows, with all calves (except replacement heifers) sold at about 20 months

Sheep: 17 ewes; 20-25 market lambs per year

Swine: 2 sows; about 27 market hogs per year

manage 36 ha of cropland, 13 ha of permanent pasture, and 20 ha of forest. This makes Sörtorp a medium-size organic farm for Sweden.

The soils are of medium quality, with slopes of 2 to 5\%. They are high in P from previous fertilization and in $\mathrm{K}$ from the parent material, with a $\mathrm{pH}$ from 6.0 to 6.5. They are fine-textured, with high clay content, having been formed from glacial clays. Therefore, they tend to stay wet, with excessive moisture more of a problem than drought. Much of the farm is drained with plastic pipes, but even that is not sufficient in very wet years. An additional complication is that the soils vary considerably in when they can be worked; a change in altitude of only $1 \mathrm{~m}$ makes a significant difference.

The frost-free season is short-typically from early June to the end of September-and the weather is highly variable. The average temperature is $-4^{\circ} \mathrm{C}$ in January and $17^{\circ} \mathrm{C}$ in July. Average annual precipitation is only about $500 \mathrm{~mm}$. It is distributed fairly evenly throughout the year, but in a "normal" year it is highest from July to September and lowest from February to April. Because of the seasonal distribution and the low evaporation at this latitude $\left(59^{\circ} \mathrm{N}\right)$, moisture deficits are not usually a problem. Supplemental irrigation is available for the vegetables.

Labor on Sörtorp is supplied, first, by the family. Kalle works full-time, yearround. Inger contributes to the extent she can, especially during the summer, but her position with Ecological Farmers is timeconsuming, and she also teaches school in Katrineholm (foreign languages). Their three children (Markus, 23; Karin, 21; and Linus, 15) also help, but all are still students, and the two oldest are away at their respective universities during the academic year.

They employ one half-time worker all year round. During short periods of high labor demand, additional local help is hired, typically three or four people. Interns are also common at Sörtorp, through an arrangement with post-secondary agriculture schools to give students practical experience with ecological farming.

\section{Production}

Sörtorp received KRAV organic certification in 1985 after a three-year conversion. KRAV's standards are based on the guidelines of the International Federation of Organic Agriculture Movements (IFOAM, 1996); indeed, KRAV was the first organic certifier to be accredited by IFOAM. A KRAV inspector makes at least one farm visit per year, which may be unannounced, and has access to the farm's financial books (Westberg, 1996; KRAV, 1998a). The farmer must keep detailed records regarding purchases of inputs and sales of farm products. Samples of soil or products may be taken for chemical analysis if there is suspicion of a violation. (A complete list, in Swedish, of KRAV's rules governing production methods is given at www.krav.se/regler/ indice.htm. It is being translated.)

The IFOAM guidelines and KRAV standards cover much more than avoidance of synthetic pesticides and fertilizers, the best-known aspects of organic farming. Both are founded on broad goals involving maintenance and improvement of soil fertility, preservation of biodiversity, conservation of land and water resources, reduced use of fossil fuels, ethical treatment of animals, an acceptable quality of life for producers and farm workers, and production of high quality foods (IFOAM, 1996; KRAV, 1998b).

Reflecting these principles, crop production on Sörtorp relies on rotations, green manures, livestock manures, and natural pest controls. Livestock production not only avoids hormones, conventionally produced feeds, and routine use of antibiotics, but also permits the animals to carry out their natural behavior, for example by having access to the outdoors (except the cattle during the winter).

Grains and forages occupy all but 4 ha of the tillable land. They are raised in a five-year rotation: a mix of red and white clover and grass (2 years); spring-sown small grain; field peas; fall-sown small grain. Sometimes subterranean clover is used as a cover crop. The grass-clover meadow is used for hay, silage, or grazing. The small grains (oats, wheat, barley, and rye) and the peas are in part sold, and in part used as feed on the farm.

Field work is done with either a 90-hp four-wheel drive or 45-hp tractor; grains are harvested using a small (8-foot), very old combine. Kalle notes that yields are "somewhat" lower than would be obtained with conventional fertilizers; however, their production costs are lower too, because they do not buy any fertilizers or other soil amendments except limestone to raise the $\mathrm{pH}$. It is difficult to make exact yield comparisons with nearby conventional farms, because the soils in the area vary sharply in yield potential.

Vegetables, although produced on only $3 \mathrm{ha}$, are important to the economy of the farm. They are grown on an old lake bed 
on soils higher in organic matter, in a fouryear rotation: two years of green manure, mainly sweet clover and grass sown with a small-grain nurse crop, followed by one year of cabbage and one year of any of several vegetables (onions, leeks, carrots, parsnips, or potatoes, depending on the particular soil). A small field is intercropped with the classic combination of sweet corn, beans, and squash, and small areas also are devoted to strawberries, chokeberries (Aronia melanocarpa), rhubarb, and apples. Vegetable production is mechanized, except for hand harvesting and occasional hand-weeding for thistles.

Choosing the right mix of vegetables is something that Kalle and Inger find both challenging and exciting: not only must each kind do well on a particular soil, they also must be well suited to each other biologically, and their demands for labor and machinery must be compatible with the farm's other enterprises. Market demand is another important criterion. The product mix at Sörtorp is constantly adjusted as experience accumulates and conditions change.

Kalle and Inger consider animals essential to the farm, not just because they enjoy raising them, but also because they make it economical to have meadow in the rotation and because they graze the untillable pastureland. The main livestock enterprises are beef cattle ( 9 cows) and sheep (17 ewes). The calves are born in the spring and are sold in the fall of the following year. They are raised entirely on farmgrown feeds, mainly hay, silage, vegetable residues, and grazing (they graze with the sheep). They get some grain during the first winter and again for one or two months before being sold. In winter they are kept in a loose housing barn converted from an out-of-date hog house.

About 20 to 25 lambs are born each spring. They are raised entirely on milk and grazing, receiving no grain. They are sold when they are 5 to 6 months old, at about $20 \mathrm{~kg}$.

There also are two sows, from which about 27 market hogs are produced per year. Because Kalle and Inger do not want to raise their livestock too intensively, the sows have only three litters every two years to allow the piglets to suckle for 11 to 12 weeks, rather than the minimum 7 weeks required by KRAV standards. They have free access to the outside, and during the summer can root in the grass or forest.

\section{Fertilization and Pest Control}

The greatest concerns in organic farming are to supply adequate nutrients and control crop pests adequately without conventional fertilizers and pesticides. However, these do not present overwhelming problems on Sörtorp. Soil tests, conducted every five years, show that available $P$ is increasing; besides the high $\mathrm{P}$ from previous conventional fertilization, additional $\mathrm{P}$ is made available from the subsoil by the green manure crops. No livestock manures or organic fertilizers are brought in from off the farm. Legumes and the farm's own animal manures provide enough total $\mathrm{N}$. The manure is applied mainly on the vegetables; the most nutrient-demanding crops, such as cabbage, receive $40 \mathrm{t} / \mathrm{ha}$. However, available $\mathrm{N}$ may be inadequate early in the season when the soil is cold, because of the low rate of mineralization.

The main pest is Canada thistle ( $\mathrm{Cir}$ sium arvense) in the vegetables, which is a particular problem in heavy soils. Besides some hand-weeding, thistle is partially controlled by the two years of green manure in the four-year rotation, but still can be a problem in some fields. Weeds between the rows are controlled mechanically; a brush weeder (an implement with slowly rotating circular brushes) is effective in controlling weeds close to the row. Weeds in the field crops are partially controlled by the rotation with clover.

The only significant insect pests are the diamondback moth (Plutella xylostella) and the large white butterfly (Pieris brassicae), whose larvae attack cabbages. Kalle and Inger prefer not using anything against them, but when the problem gets serious (about one year in four) they apply Bacillus thuringiensis, a microbial pesticide permitted in organic farming. Aphids occur on the small grains, but ladybird beetles control them adequately. Diseases of small grains usually are not serious, and nothing is done about them.

The most persistent production problem, as already mentioned, has been the soils' tendency to remain excessively wet and become compacted. How best to work these high clay soils was the most important thing they had to learn when in 1982 , by then experienced organic farmers, they moved to Sörtorp from the rented farm, which had light, sandy soils. The effort took many years of experimentation. In some years they managed without plowing. This improved the soil structure, but also led to problems with weeds. Nowadays they usually plow in the spring, using a three-bottom moldboard. Crop residues and green manures are handled primarily by the cows and sheep.

Compaction is not usually a special problem of organic farming, and would also have presented difficulties under conventional management. In fact, it was more serious when Kalle and Inger began farming Sörtorp after it had been managed conventionally for many years. Since then, the organic rotations, with their green manures and rotation meadow, have helped improve soil physical conditions. Also, they use relatively small tractors with wide tires, and avoid working wet soil.

\section{Marketing}

The vegetables are sold through a regional food cooperative that exclusively markets organic vegetables and potatoes, mainly to food chains. The grain is sold through wholesale and processing companies, with the help of people from the organic movement. The livestock are sold to a slaughterhouse that processes both organic and conventional livestock, but markets them separately. The strawberries are sold through pick-your-own or to local shops; the rhubarb is sold through a new cooperative (described later).

All products are sold at premium prices. However, it is difficult to say how much the premiums are, because the organic market is "thin" and can easily be overor undersupplied at any given time, making the premiums very volatile. Also, the organic market typically demands products that are of very high quality in all respects, so that the relevant comparison is to high quality conventional products, not the average. Consequently, Kalle could only give these estimates for the organic premiums: grains, 5 to $50 \%$; vegetables, 0 to $100 \%$; livestock, about $20 \%$ for cattle and somewhat higher for pigs.

Unlike some farmers, both organic and 
conventional, who mainly want to be producers and not concern themselves much with marketing, Kalle and Inger are very attentive to consumers' demands regarding both the kinds and the quality of their products. Maintaining quality is a big job, but they welcome the challenge: "It feels right to be concerned about the quality of our products. To us it is self-evident that we should look after nature and the environment when we use the land and the animals, but it also is stimulating to hear that our vegetables are fresh and good."

\section{Behind the Production Methods: An Organic Concept}

By itself, organic management does not make Sörtorp unusual in Sweden today (although it was a lot more unusual back in 1982). Rather, what makes it stand out is the careful, thorough way that Kalle and Inger have worked out a system for their particular farm that embodies the broad principles of organic farming, not just the specific production restrictions required for certification.

The foundations of organic farming, for them, are "to make optimum use of local resources, to recycle as much as possible, to be self-reliant for resource and ecological reasons, and to improve the quality of the landscape, soil, and food." For Kalle, the key to developing a well-functioning organic system that reflects these principles is to "look at your own farm to see what can be done on it with its particular resources."

Because of the goal of self-reliance, they do not use any feeds or manure from off the farm, although the certification standards would allow this, with some restrictions. Instead, they make sure that livestock production is matched to the farm's ability to produce feeds, and that the manure supply is matched to the crops' nutrient needs. For example, responding to the recent development of an organic beef market, they increased beef production by growing grass-clover for two years instead of one. Not coincidentally, the change also was beneficial for soil structure and crop nutrient supply.

A general principle in managing Sörtorp is to try to use everything: "That's our specialty, to use every niche of the farm,

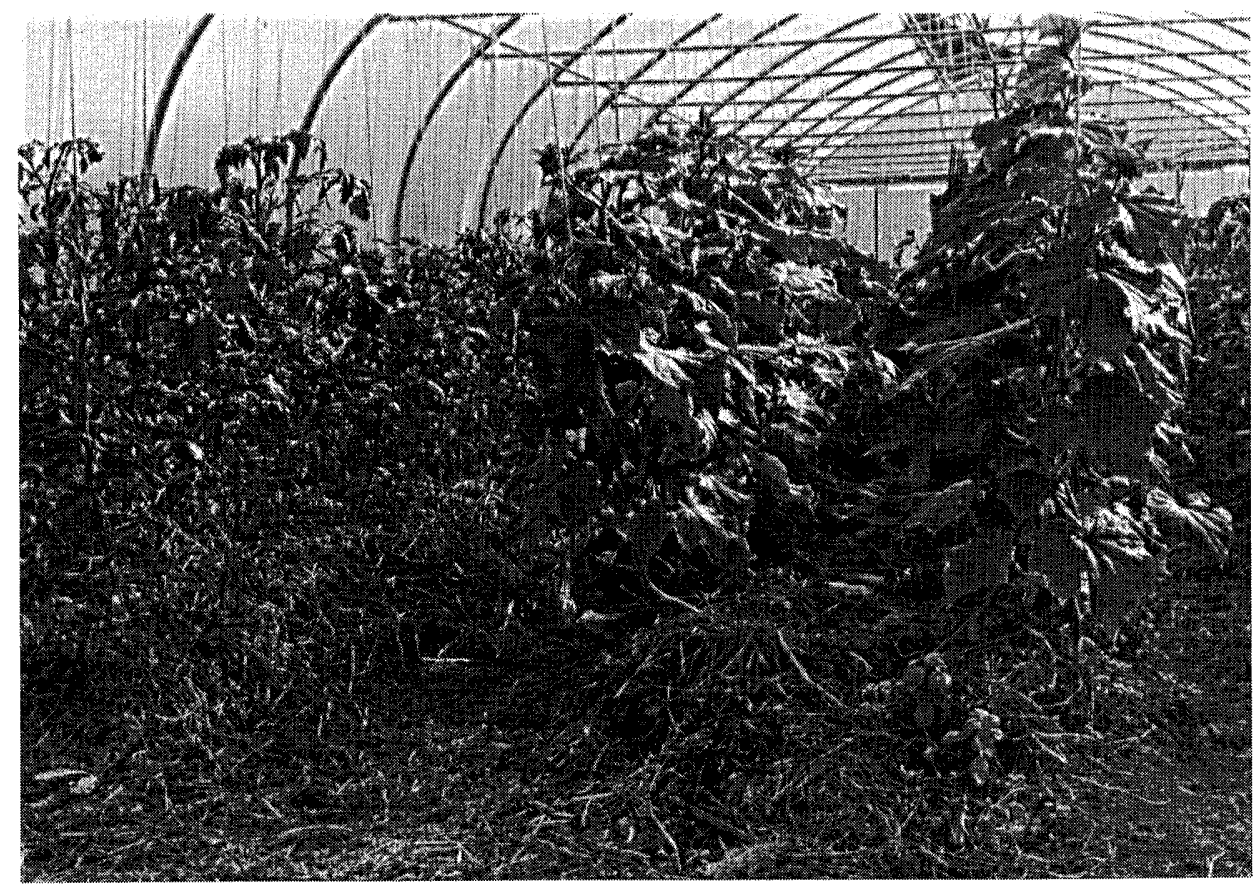

Figure 1. Vegetables growing in a greenhouse used for livestock housing in the winter and seedling production in the spring. (Photograph by Nora Murphy.)

even parts where a conventional farmer would say "there is nothing we can do with that," says Kalle. To make it worthwhile to use every piece of the farm often means finding multiple uses for it, either for production or for environmental benefit. For example, they built a plastic greenhouse in 1996, mainly to produce seedlings. But because that takes just a short portion of the year, they also use it to shelter sheep in the winter and to grow vegetables such as cucumbers and tomatoes after the seedlings, taking advantage of the manure that the livestock deposited during the previous winter (Fig. 1). They acknowledge that they don't produce as many vegetables in the greenhouse as a conventional grower would, but they don't have to, because the vegetables just complement the other uses, providing an extra source of income. The greenhouse also serves as an attractive site for meetings.

Besides trying to find a use-or many uses-for each part of the farm, Kalle and Inger seek to integrate the separate parts into a well-functioning system. For example, the field crops that support the livestock do not need to receive all the manure produced by those livestock, because of the $\mathrm{N}$-fixing legumes in the rotation; therefore, manure is available for vegetable production. Also, the lambs graze the vegetable residues; besides contributing to livestock production, this eliminates the possible environmental problem of nitrogen leaching from cabbage leaves after harvest.

Their uncropped land is an interesting example of how "nonproductive" resources can help achieve the varied goals of the farm as a whole. The farm has several hectares of hage, a landscape with widely spaced birch trees and a diverse undergrowth of grass and wild flowers. Under careful management, livestock graze the hage to keep it open and clear of brush and to optimize the desired species mix (Fig. 2). Besides providing forage, this maintains a landscape type that traditionally has been prized in Sweden but has greatly declined recently (they are subsidized by the European Union's Environmental Programme for managing it this way). Moreover, according to Inger, "if you do it right, you get a high biodiversity that supports predators of insect pestsinsects, birds, and frogs." Thus, the production of feeds and livestock combines with management of the adjacent forest land for their mutual benefit.

Even compared with other organic farms, which typically are more diversified than conventional farms, Sörtorp is highly diversified. Diversification requires much more management skill and 


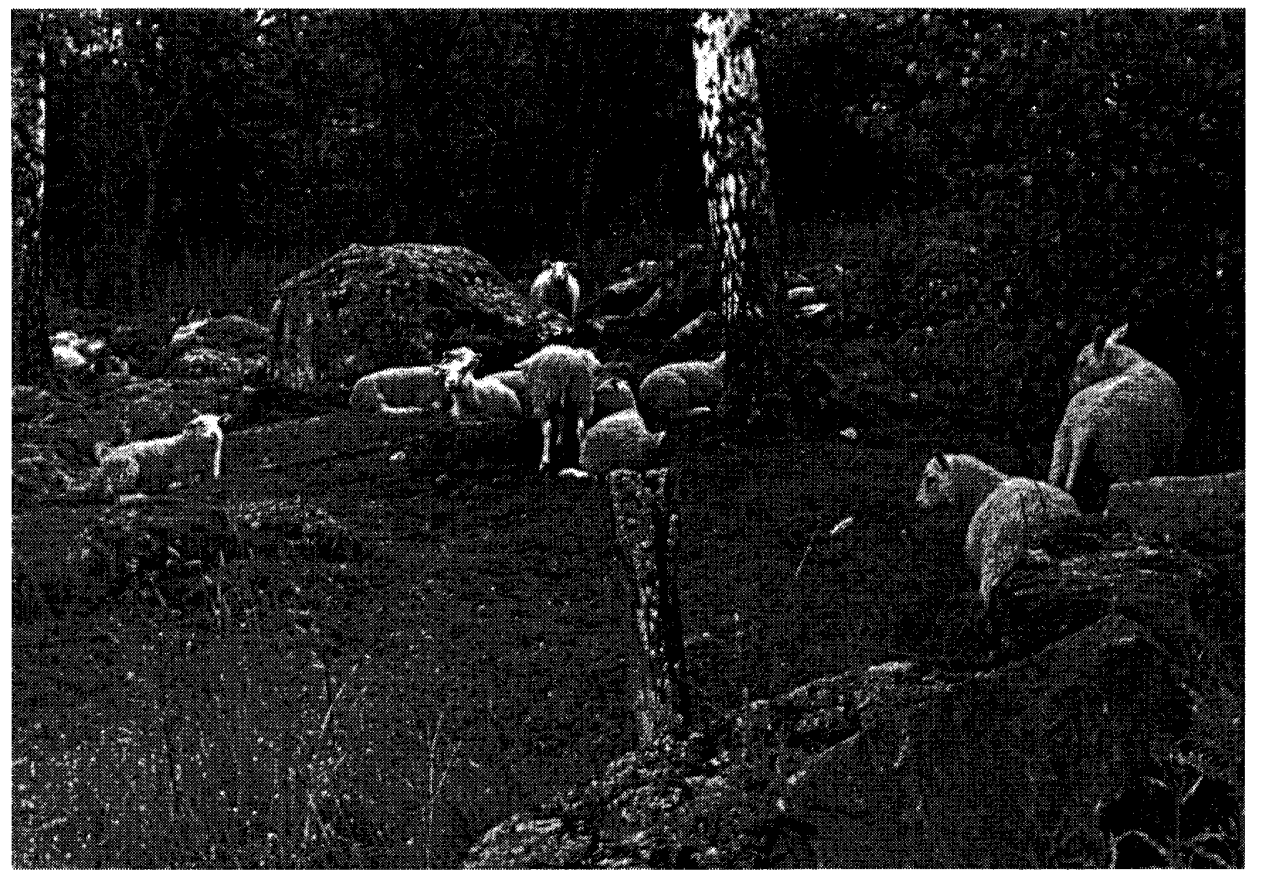

Figure 2. Sheep grazing on woodland pasture, where they are used to manage the mix of plant species. (Photograph by Nora Murphy.)

effort than just concentrating on a few enterprises and learning to do them well. It also might require expanding the farm so that each enterprise is large enough to be worthwhile. But Kalle and Inger have pursued an attractive alternative to expansion: they cooperate with other small- and moderate-size farmers to gain economies of scale. They recently formed a cooperative of 13 organic growers who started raising rhubarb for processing into juice by a small local food processing plant. Individually, these growers would not have produced enough to meet the processor's needs, but together they can. Rather than competing, therefore, they are helping each other. They visit each other's farms, sharing their experiences to become better rhubarb growers. Kalle and Inger consider the social aspect of the cooperative very important, not just its purely economic benefits.

Clearly, much thought and effort has gone into managing Sörtorp according to the principles of self-reliance, diversity, environmental protection, and whole-farm integration. The process is never-ending; within the past three years, a greenhouse was built, chokeberries and rhubarb were introduced, and the field crop rotation was changed from seven to five years. Plans are in the works to expand the rhubarb cooperative to include chokeberries, strawberries, and apples.

\section{Rewards and Reflections}

Sörtorp obviously demands a great deal of effort. What does it give in return?

In part the rewards are economic. Kalle estimates that the farm provides about onefourth of the family's cash income, plus an attractive place to live, a large share of their food (all their red meat and most of their vegetables), and a supply of firewood.

But the standard assumption beloved of agricultural economists ("We assume the farmer is a profit maximizer," or its less explicit but more presumptuous equivalent, "We assume the farmer is economically rational," or even worse, merely ". . . is rational") hardly applies here. Could they make more money by farming conventionally? Perhaps, although it is difficult to say, because a conventional operation would raise different products. Moreover, as Kalle notes, "conventional" management could take many forms, with conventional systems differing among themselves as much as they differ from organic.

What is more important, the question is irrelevant, because for Kalle and Inger, farming conventionally is not an alternative. All that matters, therefore, is that they are content with how much money they make from the farm. (They are not content, though, with how hard they have to work to make that much, a problem they attribute to the depressed economic situation for agriculture generally.) Conventional management might pay them more, but Inger would not then say that "it's beautiful to work a farm like this, where you see the landscape improving." About organic farming, Kalle says "it's more fun." $\mathrm{He}$ appreciates that "the people are nice. You can meet a lot of people doing interesting things and have interesting discussions with them."

Could anybody do it? Skeptical of Inger's disarmingly modest answer-“"Of course!"-I asked for elaboration. For her, it's a question of attitude: "You have to believe in what you are doing. You have to be brave and creative and try different things. That's how you work out a system. We laugh at our mistakes and at how crazy we are."

Clearly, Sörtorp is a special place for them: "We live close to our visions here. We have thought a lot about our goals, and in many ways have achieved them."

No doubt farmers of all kinds wish they could say that. When you meet two people who truly can, it is a very nice feeling.

Acknowledgment. I appreciate the hospitality that Kalle and Inger extended to me during two visits (June 1997 and April 1998). Sarah Wernick made many valuable suggestions on an earlier version.

Note: Further information on Sörtorp and the two organizations mentioned is available on the World Wide Web. Sörtorp's site (home7.swipnet.se/w70996) currently is only in Swedish, but an English version is being developed; Ecological Farmers of Sweden (home6.swipnet.se/w-60294) and KRAV (www.krav.se) both have English pages on their web sites.

\section{Reference}

1. Ekologiska Lantbrukarna i Sverige. 1996. The Swedish Ecological Farmers Association (pamphlet). Uppsala, Sweden.

2. IFOAM. 1996. Basic standards for organic agriculture and processing and guidelines for coffee, cacao and tea; Evaluation of inputs. International Federation of Organic Agriculture Movements, Tholey-Theley, Germany. 
3. KRAV. 1998a. KRAVs kontroll, lantbruk. (KRAV's inspection, agriculture.) www.krav.se/kontr.htm (accessed October 19).
4. KRAV. 1998b. Kravs mål och syfte. (KRAV's goals and purpose.) www.krav.se/mal.htm (accessed October 12).
5. Westberg, Lotten. 1996. KRAV-Kontrollanten: Jag känner mig inte som någon snokare. (KRAV inspector: I don't consider myself a spy.) Ekologiskt lantbruk (Uppsala, Sweden) 7/96:12-14.

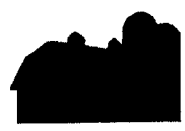

\section{UPCOMING EVENTS}

May 17-19, 29th Annual Composting and Recycling National Conference will be held in Albuquerque, N.M.; contact BioCycle Magazine, 419 State Ave., Emmaus, PA 18049; 1800-661-4905.

May 19-20, Summit on Organic Food Technology will be held in Gilroy, CA; contact Gay Franklin, SOFT, (408) 842-4893; e-mail gvnc@safemail.com

May 21-23, American Livestock Breeds Conservancy's Annual Conference will be held in LaFox, IL; contact Cynthia Ehrman, ALBC, P.O. Box 477, Pittsboro, N.C. 27312; (919) 542-5704.

May 23-28, 10th International Soil Conservation Organization Conference will be held in West Lafayette, IN; contact Nona Schaler, Purdue University, 1-800-359-2968 ext. 92N; e-mail njschaler@cea.purdue.edu; on the Internet, http://topsoil.nserl.purdue.edu/isco99/ isco99.htm
May 26-29, “Permanent Agriculture: Designing Our Farms for a Future That Matters" will be held in Buena Vista, VA; contact Good Earth Farm School, (540) 261-8775.

June 3-6, "Crossing Borders: Food and Agriculture in the Americas," the joint meetings of the Agriculture, Food, and Human Values Society, and the Association for the Study of Food and Society, will be held in Toronto, Canada; contact Elias Chu, (416) 979-5135; email echu@acs.ryerson.ca

June 4-6, June 11-13, June 18-20, and June 25-27, "Planting the Future" will be held in Rutland, Ohio; contact United Plant Savers, P.O. Box 420, East Barre, VT 05649; (802) 479-9825; e-mail info@www.plantsavers.org

June 6-8, "NABC 11: World Food Security and Sustainability: The Impacts of Biotechnology and Industrial Consolidation," the 11th annual meeting of the National Agricultural
Biotechnology Council, co-hosted by the Wallace Institute, will be held in Lincoln, NE; contact the Center for Biotechnology, University of Nebraska-Lincoln, (402) 472-2635; or NABC, (607) 254-4856; e-mail nabc@cornell.edu

June 6-9, "Keep America Growing: Balancing Working Lands and Development," sponsored by the USDA's Natural Resources Conservation Service and others, will be held in Philadelphia, PA; contact the conference coordinator at (802) 655-7769; e-mail delaney@together.net

June 9-12, "Third National Workshop on Constructed Wetlands/BMPs for Nutrient Reduction and Coastal Water Protection"' will be held in New Orleans, LA; contact Dr. Frank Humenik, Box 7927, North Carolina State University, Raleigh, N.C. 27695; (919) 515-6767; e-mail frank humenik@ncsu.edu

\section{RESOURCES}

"Cultivating Diversity: Agrobiodiversity and Food Security" is available from World Resources Institute, $10 \mathrm{G} \mathrm{St.,} \mathrm{NE,} \mathrm{Washington,}$ D.C. 20002 ; on the Internet, http://www.wri.org/wri/

"Pests of the Garden and Small Farm: A Grower's Guide to Using Less Pesticide," 286 pages, is $\$ 35$; “ $1999-2000$ Catalog”' of publications, videos, and slide is free; both are available from the University of California, DANR Communication Services/Publications, 6701 San Pablo Ave., Oakland, CA 94608; (800) 994-8849, or (510) 642-2431.

"Getting Food on the Table: An Action
Guide to Local Food Policy" is $\$ 12$ from Community Food Security Coalition, P.O. Box 209, Venice, CA 90294; (310) 822-5410.

"Adding Value for Sustainability" is $\$ 8.50$ plus $\$ 3$ shipping from Pennsylvania Association for Sustainable Agriculture, ATTN: Kristen Markley, P.O. Box 419, 114 West Main St., Millheim, PA 16854; (814) 349-9856; emailksm6@psu.edu

"Agricultural and Conservation Policies: 2002 and Beyond," proceedings from a workshop in honor of Norman A. Berg, is available from Center for Agriculture in the Environment, American Farmland Trust, P.O.
Box 987, DeKalb, IL 60115; 1-800-370-4879, or (815) 753-9347.

"Regional Trade Agreements and U.S. Agriculture"' is available on the USDA's Economic Research Service Website at http:// www/econ.ag.gov, or from the USDA, 1-800999-6779.

"Statewide IPM Project/University of California," the 1998 annual report, is available from the University of California Statewide IPM Project at (530) 752-7691.

"1999 National Organic Directory" is $\$ 47.95$ plus $\$ 3$ shipping from Community Alliance with Family Farmers, P.O. Box 363, Davis, CA 95617; 1-800-852-3832. 


\title{
Is precision agriculture sustainable?
}

\author{
Jan van Schilfgaarde
}

\section{Background}

At the present time precision agriculture (Prec $\mathrm{Ag}$ ) is one of the most discussed topics in agricultural production, industry, and research circles. First conceived in the mid 1980s, it came into its own in the mid '90s. The purpose of this discussion is to examine Prec Ag for what it is and where it seems to be going, and then to speculate on its impact on agricultural producers, on rural communities, and on agriculture generally.

It is a popular topic, with at least four recent international conferences in the United States (e.g., Robert et al., 1996), a European conference held in England (Stafford, 1997), and a "Western Precision Agriculture" conference held in Boise, Idaho, in 1998. Proceedings of these conferences tend to run to 1000 pages.

\section{Definition}

Prec $\mathrm{Ag}$ (some prefer the term Site Specific Agriculture) makes use of the rapidly evolving electronic information technologies to modify land management precisely in a site specific manner as conditions change spatially and temporally. Prec Ag might be defined as a form of crop production that adjusts management practices based on the temporal and spatial variation found in the managed land area.

Jan van Schilfgaarde is former Director of the Pacific West Area of the Agricultural Research Service, USDA at Albany, California. Retired, he now resides in Fort Collins, Colorado.

Volume 14, Number 1, 1999
You will note that this definition restricts Prec Ag to crop production. Nothing is said about animal production or the integration of the two in a farming system. In principle, such a restriction need not apply, but in practice that is what has happened to date. Also, nothing is said about marketing strategies. In a report commissioned by the USDA, a committee of the National Research Council's Board on Agriculture (NRC, 1997) adopted a much broader definition-a management strategy that uses information technologies to bring data from multiple sources to bear on decisions associated with crop production. Here the emphasis is on the "Information Highway" rather than on land management.

\section{Expectation}

The expectation is that Prec $\mathrm{Ag}$ will increase crop yields, enhance net returns from farming, and, at the same time, reduce environmental insults.

In one sense, Prec $\mathrm{Ag}$ is what farmers used to do until modern mechanization increased farm size, and monocultures became dominant. For example, farmers used to vary their manure applications depending on local (site specific) need, to use a hoe (or their hands) to clean patches of intensive weed growth and, in general, to know the idiosyncrasies of their farmstead and to adjust management practices accordingly. Also, crop selection and crop rotations were used to adapt to localized conditions. Now sophisticated techniques promise to act as surrogates for farmer knowledge and to supplement it, and thus, in a technologically refined manner, again to account for variability.

\section{Relation to Other Technological Advances}

Early waves of new technologies that have swept through agriculture generally came about because of a specific quest for new ideas thought to be useful in farming. Thus mechanization, fertilizers, pesticides, and hybrid seeds were innovations for and by agriculturists. With Prec Ag, there is a subtle difference. Most of the technology that makes Prec Ag possible was developed for other purposes-primarily the military — and then found useful in agriculture. Specifically, global positioning systems (GPS) and geographic information systems (GIS) were developed by the defense industry. Without these technologies we wouldn't be concerned with Prec Ag today. Granted, yield monitors and variable rate chemical applicators (VRT) were specifically developed for agriculture by the agricultural machinery industry, so that better use could be made of GPS. One consequence of this transfer of technology from the outside is that there are entrepreneurs not historically concerned with agriculture who are anxious to explore new business opportunities.

Thus, another description of Prec Ag might be "a technology driven system for identifying temporal and spatial variations across a field or landscape and for adjusting management practices accordingly." 


\section{Measuring Variability}

What are these variations that need to be identified? That is a crucial question for which there still is not a fully satisfactory answer. We can measure numerous things, some remotely or in passing, others by taking samples to a laboratory. For example, we can measure slope, aspect, soil organic matter, soil nitrogen or phosphorus, soil profile water, biomass, crop canopy density, dead plants, crop yield, etc. But how do we derive information from these data?

\section{Two Approaches to Prec Ag}

Before addressing that question, it may be useful to distinguish among various approaches that are being used. One approach is to collect data on soil and plant characteristics by remote sensing, field sampling and laboratory analysis, or other techniques, and to enter these data on a map through a GIS. If one knows how to adjust management based on the recorded characteristics, a prescription can be written and overlain on the information system. Soil $P$ status may be interpreted to determine fertilization rate, or soil organic matter to adjust herbicide rate. A key element of this approach is the time lag between developing the information and the consequent action.

Another approach is to use sensors that make measurements "on-the-go" and then send a signal to modify a management process. For example, a measurement of leaf water potential may be used to adjust the irrigation rate as the irrigation system advances through the field, or of leaf chlorophyll content to change $\mathrm{N}$ applications. If a sensor can identify the presence of a weed, it can trigger an herbicide application. In such cases, a GIS or GPS is not needed, although together they may serve a useful purpose in keeping records.

Most of the public's attention has been directed toward the first of these approaches, specifically on yield monitoring. Several manufacturers now sell grain yield monitors. Schueller (1997) reported that over 20,000 combines were already equipped with yield monitors. Potato yield monitors are also on the market, and monitors for other crops will soon follow. VRT is routinely available for farmers willing to pay for the service; it allows the application of lime or fertilizer according to the data in a GIS map. These advances depend on the great progress made in recent years in GPS technology. Until recently, it was an expensive toy that, for civilians, could locate a point in the field within 10's of meters. Now, at a much lower cost, an accuracy of 1 to $2 \mathrm{~m}$ is easily obtained and, for a price, an accuracy of 100 to $200 \mathrm{~mm}$ is attainable. To attain this high resolution, use is made of DGPS, or differential GPS, where the satellite signals are corrected by means of a stationary, ground-based signal.

\section{A Plethora of Data}

Notwithstanding the documented progress and the proliferation of scientific papers, there still are numerous unanswered questions. Most of them come down to the dilemma that data don't necessarily represent information. To illustrate, a yield map provides an interesting color display, but doesn't automatically identify the management practice to be changed. Does a low yield reflect lack of soil depth and thus call for reduction in fertilizer, or does it reflect an impoverished soil and thus call for an increase? From a practical point of view, the jury is still out as to the effectiveness of Prec Ag. The literature has few examples of an economic return or of improved environmental conditions. For example, Ferguson et al. (1997) found that theoretically (by modeling) N scheduling by need should provide an economic return, but field tests did not confirm that prediction. Comparing results obtained when $\mathrm{N}$ needs maps were developed using various techniques-grid samples and a yield map, among others-gave disappointing results. None of the methods was very effective. They argued that, ultimately, on-the-go sampling of leaf chlorophyll content (in irrigated maize) to adjust $\mathrm{N}$ application rates is promising. To this author's knowledge, there is no documented evidence that Prec Ag consistently increases farmers' returns or reduces pollution.

Similarly, Prec Ag weed management is still in its infancy. A plant that is out of place can be readily identified, and hooded sprayers are available to kill any plant found between rows in row crops. Other than that, one is still reduced to scouting. Such scouting can then lead to a map through use of GPS. A set of pattern recognition sensors is needed that can note the presence of specific weeds and then send a signal to schedule appropriate treatment.

\section{Need for Sensors}

In general, in Prec Ag more and better sensors are needed. Even yield monitors, widely available and sold, suffer from lack of reliability because it is difficult to determine the width of cut and thus the size of the area sampled. A thoughtful paper by Sudduth et al. (1997) describes progress in sensor technology. Sensors have been developed and often made available commercially for soil organic matter, soil nitrate, total soil nitrogen, soil profile water content, soil salinity, and other soil properties. Some are highly reliable; most are not. Other sensors measure crop canopy temperature and other crop characteristics.

A special class of sensors concerns remote sensing, a technology some 40 years in development. Examples of the use of remote sensing data in real time (more realistically, short time span) management advice in agriculture are not numerous. Despite great progress in remote sensing technology, its application in agriculture has been disappointing. The recent developments on GPS and related areas may change that; remote sensing may become an integral part of Prec Ag.

\section{An Assessment of Prec Ag}

This is not the place to review progress and problems in Prec Ag in detail. The foregoing sets the stage adequately. A combination of new technologies is being introduced to agricultural crop production; they promise to change the way farmers operate. Using sophisticated computerdriven technology, participating farmers will have access to extensive data bases that can be used to drive their operations by adjusting management techniques in a site-specific fashion. The process is billed as a way to reduce the use of chemicals, reduce costs and increase net returns, and abate pollution. To date there is no hard evidence of a significant reduction in chemical use or of environmental benefits. Multitudes of data are being collected, but 
there is a dearth of information on how to interpret these data in a meaningful way.

It serves no purpose to debate whether Prec Ag is good or bad, or whether it deserves support or not. There is no turning back, even if that were desirable. What may be useful at this stage is an assessment (or speculation) of the impact of these developments on agriculture and its structure.

It has been argued that the expected benefits from Prec Ag obviate the need for special research and education programs in water quality, farming systems, and sustainable agriculture; that argument has no merit. Water quality and quantity issues go far beyond the possible reductions in nitrates or pesticides that may result from Prec Ag. Furthermore, Prec Ag deals with managing current farming systems more efficiently, not with the issue of assessing and modifying them to make them more environmentally friendly and more sustainable, more robust, and less dependent on external inputs. Prec Ag does not deal with the integration of crop and livestock enterprises. The prominence of Prec Ag does not reduce the need to maintain strong programs in water quality and farming systems. The sustainable agriculture agenda diverges even more from that of Prec Ag, as addressed later.

\section{The Impact of Prec Ag}

Not just the inevitability but also the desirability of Prec Ag is seldom questioned. Industry, academia and many professional societies are actively in support (e.g., ASAE, 1997). Who can question the benefits of applying newly emerging technologies so that farmers can increase their economic efficiency while making more effective use of their resources-land, soil, water, seed, fertilizer, etc.? Who doesn't support management practices that reduce negative impacts on the environment? Never mind that few of the benefits are being realized today.

There is little doubt that precision management will be a reality in the future. It is also clear that these new techniques will have a drastic impact on how farms are managed. The NRC report (1997) carries this thought further by suggesting the extensive use of elaborate data bases, which are expected to accumulate, in marketing decisions by farmers and non-farmers alike. The report expresses concern that such data bases could readily be misused, and it calls for codification of property rights. It asks the question whether Prec $\mathrm{Ag}$ will favor large, commercial farms at the expense of smaller family farms and then answers the question in the negative. As with the introduction of mechanization, fertilizers, pesticides, and hybrid seeds, the writers of this report thought that this next step in modernization can only bring good.

Let us stipulate that many good things may flow from the adoption of Prec Ag. Let us stipulate also that Prec Ag will ultimately produce many of the beneficial results now predicted. That still leaves the question of its impact on rural communities and thus on the nation as a whole.

Long before Prec Ag was seriously considered, Wendell Berry (1996) lamented the deterioration of rural communities, pleaded that farming is an art, that farms and soils are alive, and that treating them as machines would further weaken the moral fiber of the nation. One doesn't have to accept all of Berry's arguments to recognize that there are some negative aspects to Prec Ag.

Although costs may come down, Prec Ag always will require an increased capital investment and greater dependence on purchased services. These purchases may include data from firms such as Resources 21 , an industrial conglomerate that expects to launch a set of satellites to serve agriculture: it will deliver detailed data to agricultural users frequently in GIS format, the details of which are still under study. Such purchases may include payment to local consultants who provide Prec Ag services. Whatever the specific details, still more of the economic activities concerning farming will be focused off-farm. A disturbing and precipitous trend will be accelerated.

Notwithstanding the conclusions reached by the Board on Agriculture's committee, it is likely that Prec Ag will favor large, corporate farms over smaller, family-operated farms. The number of farms in this nation has already been reduced to about 1.7 million and it continues to decline. Prec Ag seems to be another development that will make it more difficult for smaller, private farms to survive.
In theory, there is no reason why Prec $\mathrm{Ag}$ should favor larger enterprises. One can visualize the emergence of consulting services to serve the smaller farmer effectively. One also can speculate that larger operators are more likely to be early adopters and thus will have relatively higher capital investments placed at greater risk. Thus it is conceivable that smaller operators who are later adopters would benefit from the innovators' mistakes. However, the odds are against the family farm.

Both of these factors, greater dependence on purchased inputs and a likely bias towards large firms, contribute to a weakening of the rural community. Larger, corporate farms also tend to be less diversified, which in turn leads to greater dependence on purchased inputs.

An entirely different concern, clearly recognized in the NRC report, deals with integrity. Extensive data sets will be developed for every participating farm or field. For many purposes, these data sets need to be merged; if they were collected by satellite or aerial photography, they had to be disaggregated before they were presented to the farmer. Who owns these data? The vendor, or the farmer? Are they available to the IRS? To what extent are one farmer's records of value to another? Or to the bank? Society will need to develop clear sets of rules on property rights, confidentiality, and public good in relation to the management of such data. Similar problems long have been dealt with in connection with other data gathering operations in USDA agencies, including the Forest Service. Prec Ag. will aggravate them.

\section{Relationship to Sustainable Agriculture}

In pursuit of sustainable agricultural systems, farmers (even more than scientists) have sought alternatives to monoculture and ways to reintegrate animal and crop production. Chicken production can hardly be called farming anymore. Large swine operations are under attack in many states. Huge dairy farms have serious disease and manure handling problems. Crop rotations that help manage pests, use of legumes to increase soil fertility, reintroduction of small grains into midwestern 
corn-soybean systems, and rotational grazing are some of the approaches being considered for greater sustainability.

Prec Ag may be seen by some as an alternative route. It is expected to reduce pollution and fine-tune chemical use to actual need. However, it indeed would be unfortunate if Prec $\mathrm{Ag}$ were to set back the still small but growing efforts, often farmer driven, that work towards recognition of sustainable management practices-practices that often obviate the need for fertilizers and pesticides, or convert manure from a liability to an asset. Such practices are directed at increasing biodiversity and reducing dependence on off-farm resources. The technological fix offered by Prec Ag provides some help in this direction, but only to a small extent. It is not a substitute. More precise use of fertilizer will not solve the manure utilization problem, and GPS will not help to establish beneficial insects or birds in hedgerows or farm woods.

In his book "The Spirit of the Soil,", Paul Thompson (1995) discusses issues of morality and ethics in agriculture. He also devotes substantial space to sustainability. In extreme form, the issue is often seen as production versus preservation. More subtly, Thompson illustrates why sustainability is philosophically an elusive concept that defies useful definition, that is difficult to evaluate in a specific system, or for which it is hard to set goals. Yet he concludes that "the ideal of sustainability indicates the end towards which (agricultural) reform should be directed"' (p. 172).

We shall not pursue Thompson's ideas in any depth here, or expound on the subtleties of his discourse. It is appropriate, however, to consider briefly the moral and ethical duty of human beings towards agriculture and, more broadly, towards the earth.

\section{Morality and Agriculture}

There are good practical reasons to be concerned with a deteriorating climate, global change, excessive erosion, and increasing resistance of pests to biocides. Such utilitarian concerns suffice for many to embrace sustainability as a goal. They are, in fact, the primary driving force behind the Sustainable Agriculture Research and Education (SARE) program in the USDA.

Besides the utilitarian, physical aspects, however, there are more fundamental issues that deserve attention. One of these is stewardship. The responsibility for "stewardship of the earth" is often put in a religious context, and sometimes it is even interpreted as a right of exploitation. A more appropriate view emphasizes responsibility rather than right. It sees the farm as a living entity, an organism, and charges the farmer with the task of inducing this entity to produce crops and livestock in harmony with the environment.

The farm as a self-contained organism is another issue. In most cases, this can only be an ideal towards which one may strive. Most farmers depend heavily on external resources (purchased inputs). Reducing this dependence tends to restore the integrity of the farm organism. Furthermore the concept of "organism" supports, or leads to, biodiversity-not so much in the sense of "saving species" or "preserving species" as in supporting organismic interactions (such as nurturing beneficial biological cycles) that keep the farm and its soil healthy, and that keep weeds, pests, and diseases in check. The objective is a biological balance where the vitality of the land permits the harvesting of crops.

Then there is the issue of family and community. Berry (1996) speaks to this with passion. The farm as an organism includes the farmer and the farmer's family. A healthy relationship to the land and respect for nature help to maintain a wholesome family. More broadly, the family farm with minimal dependence on purchased inputs (or wholesale markets) is an integral component of a healthy community. It is in such communities that the moral strength of the nation is found. Parenthetically, the emergence of Community Supported Agriculture grew out of the desire to build community spirit and to rekindle a connection between city dwellers and the land.

Thus there is a philosophical and moral basis for driving agriculture towards sustainability, as well as a utilitarian basis. The word "sustainable," poorly defined as it is, is simply a convenient label to denote "in harmony with nature, yet able to meet its obligation to mankind."

\section{Conclusions}

Prec Ag is not good or evil in and of itself. It is a natural outgrowth of technological development and it promises to offer a number of benefits. Prec Ag, however, may make it more difficult to attain sustainability. Prec Ag is coming. Thus it behooves us to learn to make appropriate use of it towards our broader goal of a sustainable society, and to avoid, or at least prepare for, the pitfalls it will bring.

\section{References}

1. ASAE. 1997. Precision Agriculture: A Position Statement. Amer. Soc. Agric. Engineers, St. Joseph, MI.

2. Berry, W. 1996. The Unsettling of America, third edition. Sierra Club Books, San Francisco, CA.

3. Ferguson, R.B., G.W. Hergert and J.S. Schepers. 1997. Strategies for site specific nitrogen management. In $\mathrm{J} . \mathrm{V}$. Stafford (ed.). Precision Agriculture '97. BIOS Scientific Publishers, Ltd, Oxford. p. 387-395.

4. NRC. 1997. Precision Agriculture in the 21st Century. Board on Agriculture, National Research Council. National Academy Press, Washington, DC.

5. Robert, P.C., R.H. Rust, and W.E. Larsen (eds.). 1996. Proceedings, Third International Conference on Precision Agriculture. Amer. Soc. Agronomy, Madison, WI.

6. Schueller, J.K. 1997. Technology for precision agriculture. In J.V. Stafford (ed.). Precision Agriculture '97. BIOS Scientific Publishers, Ltd, Oxford. p. 33-44.

7. Stafford, J.V. (ed.). 1997. Precision Agriculture '97. BIOS Scientific Publishers, Ltd, Oxford.

8. Sudduth, K.A., J.W. Hummel, and S.J. Birrell. 1997. Sensors for site specific management. In F.J. Pierce and S.J. Saddler (eds.). The State of Site Specific Management for Agriculture. Amer. Soc. Agronomy, Madison, WI. p. 183-210.

9. Thompson, P. B. 1995. The Spirit of the Soil. Routledge, New York, NY. 
Under the Blade: The Conversion of Agricultural Landscapes. Edited by Richard H. Olson and Thomas A. Lyson. 1998. Westview Press, 5500 Central Ave., Boulder, CO 80301-2877. xxii+459 pp. \$25.00, ISBN 0-8133-3597-3, paper.

By now the number of studies on farmland loss and farmland preservation has grown to become a considerable body of literature. Surprisingly, perhaps, there are few truly comprehensive assessments of the problem and techniques to resolve it in one volume. This book seeks to fill that void. Like most collections, it is uneven in quality. Some of the chapters are quite good, while others are more limited in their utility. And then there are a few, especially those that deal with landscape aesthetics and ethics, which are too rarely included in discussions of the topic and are genuinely innovative. Taken as a whole, Under the Blade is as good a collection on the problem as one is likely to find.

I am especially impressed by some of the basic premises of the book, not the least important being that the loss of farmland is either a more or a less serious issue depending upon where you sit in terms of the problem. For those who see things largely from a national and statistical perspective, the problem is modest in scope. But for those who understand that the conversion of agricultural land can have serious local consequences, and is largely the result of many small decisions and choices, then the problem can be of profound importance. Likewise, there is a keen appreciation reflected throughout the book that enhancing the economic viability of agriculture is a key to land preservation. Together, these two themes, along with several others, make for a very convincing argument.

How all of this works out is defined in a series of excellent local case studies from throughout the country. These document the nature of the land conversion problem in nearly all regions, with assessments of how various techniques and local policy regimes have responded to the larger issue. Together, the case studies and the thematic chapters combine to make for a wellrounded treatment.

While one of the chapters seeks to create a rationale for a national policy framework for farmland preservation, this collection actually makes the case for more local programs to address the issue. Indeed, some of the most creative responses to the larger problem of agriculture, like CSAs, land trusts, sustainable agriculture initiatives, and food system analyses, lead us to the inevitable conclusion that, as profound a national problem as this is, it will likely be fought on the local front and in the context of local planning boards, economic development commissions, agricultural committees, and similar bodies. And as the connection is made between agricultural land preservation and the emerging national debate on sprawl and "smart growth" - likely to become a theme in the next presidential electionUnder the Blade is likely to be an important source of information and strategy.

Mark B. Lapping, Muskie School of Public Service, University of Southern Maine, Portland, ME 04104-9300.

Sustainability in Agricultural and Rural Development. Edited by Gerard E. D'Souza and Tesfa G. Gebremedhin. 1998. Ashgate Publishing Company, Brookfield, VT 05036. xvii+245 pp. $\$ 72.95$, ISBN 1-85521-977-8, hardcover.

In the blurb that accompanied Sustainability in Agricultural and Rural Development, the publisher notes, "A unique aspect of this book is that the topics addressed have not been previously explored together in one publication." [italics mine.] Put another way, depending on one's perspective, D'Souza and Gebremedhin have assembled a set of papers that represent the good, the bad, and the ugly of sustainability. There are twelve chapters in the book, eight of which have an economist as the lead or sole author. Two chapters are written by sociologists, one by an anthropologist, and one by a soil scientist.

While economists dominate the book, they do not speak with one voice. Tweeten and Amponsah, for example, tell us in Chapter 3 that "The sustainability of American and world agricultural growth depends on [among other things]...a well functioning market that will ensure having efficient farms and agribusiness firms continually developing and adopting new technology and management practices" (p. 62). Erik Lichtenberg in Chapter 8 states that, from an economics perspective, "...sustainable development cannot necessarily be said to be unambiguously better than unsustainable development' (p. 150). And Zilberman and Lipper in Chapter 11 simply note that "Inappropriate incentives are the main reason for pollution and environmental degradation"' (p. 213).

These statements reflect a fairly straightforward neoclassical approach to sustainability issues. Markets and incentives are the tools that will lead to a more sustainable future. Neill Schaller, another agricultural economist, on the other hand, offers a less economistic take on sustainability when he asks "...what combination of local, state, and federal policies can effectively nurture social capital and thereby foster the kinds of civic engagement that will best support sustainability" (p. 167).

The debates between the more orthodox market-based economists and those who believe that governments and the local citizenry have a role to play in building a sustainable future are complemented by articles written by the sociologists and anthropologists. Flora and Kroma, in Chapter 6 , address the role of gender in sustainable development and make the important point that "Sustainable agriculture and rural development can best be achieved when women's voices from a variety of locations are heard and responded to" (p. 113). Clay and Reardon, in Chapter 7, 
show us how population and sustainability are interrelated. Until we develop effective population policies, especially in the developing world, we cannot hope to deal with sustainability problems. And Salamon, Farnsworth, and Bullock, in Chapter 5 , alert us to the importance of cultural and social aspects of sustainability. As they note, "Conventional families reject what sustainable adopters culturally value....Sustainables and conventionals are marching to different drummers"' (p. 100).

The concluding chapter by Ahearn and
Whittaker calls for cross-disciplinary collaboration on sustainability. While I applaud the upbeat tone and optimism in this chapter, the challenge will be for economists to abandon the mantra of efficiency and markets and begin to embrace a more socially constructed view of the world. This is a lot to ask of a discipline that has served as the organizational blueprint for conventional agriculture for the past century.

Most everyone concerned with sustainability will find something to like and to dislike about the viewpoints expressed in Sustainability in Agricultural and Rural Development. The relatively steep price may discourage classroom use. Finally, the book could have been more tightly edited, but as D'Souza and Gebremedhin note in their preface, "Editing of the chapters was minimized to preserve the unique flavor... of the individual authors" (p. xiv). I have my favorite flavors and I'm sure you will too.

Thomas A. Lyson, Department of Rural Sociology, Cornell University, Ithaca, NY 14853.

\section{INSTITUTE NEWS}

\section{Wallace Board Re-Elects Officers, Announces Reorganization}

The Wallace Institute Board of Directors has re-elected officers and announced reorganization plans for the Institute. Three board members were re-elected to serve another term: Christine (Cass) Peterson, owner/operator, Flickerville Mountain Farm and Groundhog Ranch; Jose Montenegro, Director, Rural Development Center, Salinas, CA; and Neil Anderson, Anderson Associates Sheep Consultants, Manhattan, KS. These members of the Executive Committee were reelected: President, Cornelia Butler Flora, Professor, Iowa State University; Vice President, Dr. Frederick Magdoff, Professor, Department of Plant and Soil Science, University of Vermont; Secretary, Cass Peterson; and Treasurer, Jose Montenegro.

The board also announced that after 16 years, the Wallace Institute will broaden its scope and reorganize to deliver its message closer to home. "Sustainable agriculture has finally achieved scientific legitimacy," said Garth Youngberg, Institute executive director, citing a multitude of sustainable agriculture initiatives at the USDA and land grant universities across the country. "When we began this Institute, our goal was to provide a safe haven for alternative farming practices that were shunned by the establishment. Now those practices are considered credible mainstream science. It is time for the Institute to focus on a new analytical agenda that includes rural development, marketing, and the environment, issues of enormous importance to all Americans, and all Americans should know about them."

At its annual meeting, the Board reviewed the challenges that remain. "Achieving scientific legitimacy is only the first step," said Board chair Cornelia Flora. "It does not mean that we have fulfilled our vision of an agricultural system that is environmentally sound, socially just, and economically viable. In many ways, our work has just begun."

To fulfill its new mission, the Wallace Institute is considering several reorganization plans, including mergers and new virtual facilities to take advantage of technological advances in communication and research. "We will have a new look," said Flora. "We will avail ourselves of cuttingedge communications technologies and build new partnership networks not available throughout much of the Institute's history."

Flora said that credible policy analysis will continue to be the heart of the Institute's work, but the agenda will expand to include environmental management, rural development, and marketing. Final decisions about the Institute's new design are not expected until later this year.
"The Institute and its founding executive director, Garth Youngberg, have contributed enormously to the success of sustainable agriculture," said Jean Wallace Douglas, the Institute's Honorary President and longtime benefactor. "Whatever turn the Institute takes, it will honor and build upon that legacy."

\section{Flora Receives Rural Sociologist Award}

Cornelia Butler Flora, Professor at Iowa State University and President of the Wallace Institute's Board of Directors, has received the 1998 Distinguished Rural Sociologist Award from the Rural Sociological Society. "She has developed high visibility programs in the areas of social capital, sustainable agriculture, women in agriculture, farming systems and rural entrepreneurship," according to the Society.

\section{Francis Named NOVA University Visiting Professor}

Charles Francis, Professor at the University of Nebraska and member of the Editorial Board of the American Journal of Alternative Agriculture, has been named the first NOVA University Visiting Professor at the Agricultural University of Norway. He is spending the 1998-1999 academic year working with a team of educators to establish a new M.S. degree program in ecological agriculture. 